Portland State University

PDXScholar

Fall 1-20-2017

\title{
Effects of Spatially Distributed Stream Power on Check Dam Function in Small Upland Watersheds: a Case Study of the Upper Laja Watershed, Guanajuato, Mexico
}

Zachary Andrew Herzfeld Portland State University

Follow this and additional works at: https://pdxscholar.library.pdx.edu/open_access_etds

Part of the Geography Commons, and the Geomorphology Commons Let us know how access to this document benefits you.

\section{Recommended Citation}

Herzfeld, Zachary Andrew, "Effects of Spatially Distributed Stream Power on Check Dam Function in Small Upland Watersheds: a Case Study of the Upper Laja Watershed, Guanajuato, Mexico" (2017).

Dissertations and Theses. Paper 3375.

https://doi.org/10.15760/etd.5266

This Thesis is brought to you for free and open access. It has been accepted for inclusion in Dissertations and Theses by an authorized administrator of PDXScholar. Please contact us if we can make this document more accessible: pdxscholar@pdx.edu. 
Effects of Spatially Distributed Stream Power on

Check Dam Function in Small Upland Watersheds:

A Case Study of the Upper Laja River watershed, Guanajuato, Mexico

\author{
by \\ Zachary Andrew Herzfeld
}

A thesis submitted in partial fulfillment of the requirement for the degree of

Masters of Science

in

Geography

Thesis committee:

Heejun Chang, Chair

Martin Lafrenz

Jiunn-Der Duh

Portland State University

2016 


\begin{abstract}
Watershed restoration comes in a variety of forms depending on which set of problems are sought to be remedied. Severe soil erosion, in the form of gullying and/or headcutting, can be mitigated through constructing check dams in well-selected locations. This practice has been used throughout the upland subwatersheds within the Upper Laja River watershed in Guanajuato, México. The present study employed Wolman pebble counts to systematically assess the effectiveness of 21 check dams located near the city of San Miguel de Allende. Particle size distributions taken directly downstream and upstream of each check dam were differentiated, aggregated and compared — with the difference between median particle size of downstream and upstream distributions defined as $\mathrm{DsD}_{50}-\mathrm{UsD}_{50}$. Several subwatershed attributes were calculated in a GIS for comparison to $\mathrm{DsD}_{50}-\mathrm{UsD}_{50}$ values. Results indicate that, on aggregate, the check dams studied were moderately successful at retaining sediment that becomes entrained in concentrated flow $\left(\mathrm{DsD}_{50}-\mathrm{UsD}_{50}\right.$ $=15.4 \mathrm{~mm} ; \mathrm{p}<0.001)$. Individually, 18 of the 21 check dams surveyed had statistically significant differences between $\mathrm{DsD}_{50}$ and $\mathrm{UsD}_{50}(\mathrm{p}<0.05)$. The subwatershed variables of local channel slope $(\mathrm{r}=0.55)$, mean subwatershed slope $(\mathrm{r}=0.46)$, subwatershed area $(\mathrm{r}=$ $0.59)$, distance from channel head $(\mathrm{r}=0.54)$, percent canopy cover $(\mathrm{r}=0.46), \mathrm{Q}_{\mathrm{med}}(\mathrm{r}=$ $0.46)$, total stream power $(r=0.58)$, and change in total stream power $(r=-0.45)$ were found to be statistically significant when correlated with $\mathrm{DsD}_{50}-\mathrm{UsD}_{50}$ values $(\mathrm{p}<0.05)$. Change in total stream power was used to classify stream reaches as either erosion or depositiondominated. When compared, the $\mathrm{DsD}_{50}-\mathrm{UsD}_{50}$ values from check dams located in erosion and deposition-dominated reaches are statistically different $(\mathrm{p}<0.05)$; higher performing check dams were predominantly found in deposition-dominated reaches. The results of this
\end{abstract}


study suggest that spatially distributed stream power can be used as a variable for making decisions about future check dam locations. In particular, check dams are more likely to be effective if they are located within deposition-dominated areas (negative change in total stream power) and in areas of decreasing change in total stream power. In general, this study's findings also support locating check dams in second order streams. 


\section{Acknowledgments}

This work would not have been possible without the generous support of Agustin Madrigal and Mauricio Sánchez in San Miguel de Allende. I am also grateful to Ecosystem Sciences Foundation_Z Zach Hill, Derek Risso, and Tim Maguire-who facilitated the connection with Salvemos el Rio Laja and provided guidance and feedback when needed. Also, I would like to thank my committee members for their support and guidance particularly during the early stages of the project. Last, but far from least, I owe sincere thanks to my family, and particularly to my wife Jessie, for their endless encouragement. 


\section{Contents}

Abstract

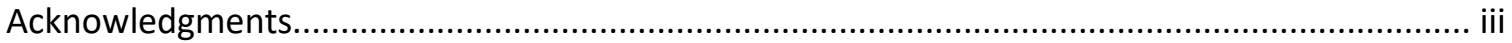

Tables

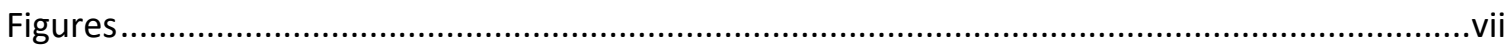

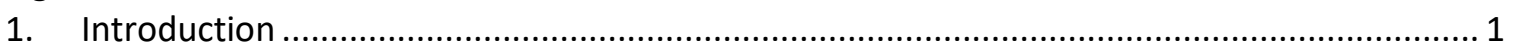

$1.1 \quad$ Land degradation stemming from soil erosion .............................................. 3

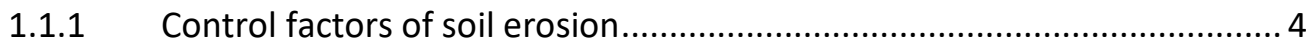

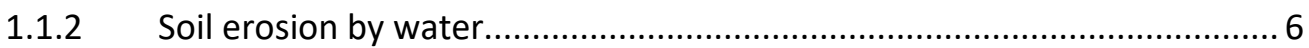

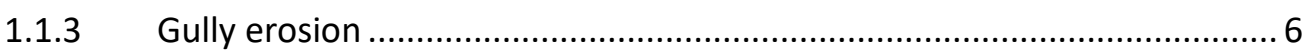

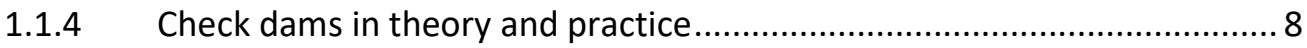

1.2 Restoration through the use of check dams............................................... 10

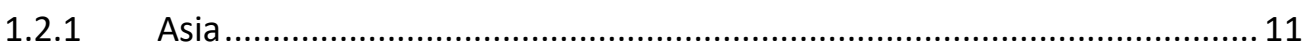

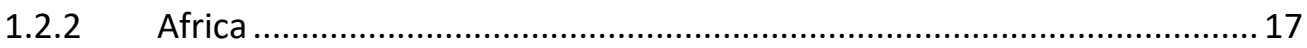

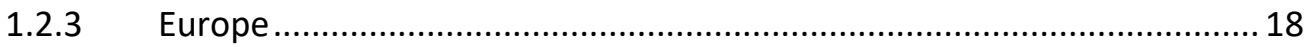

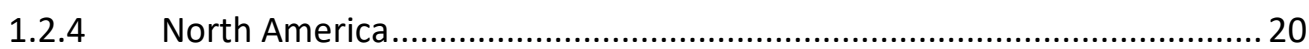

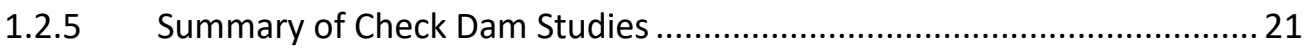

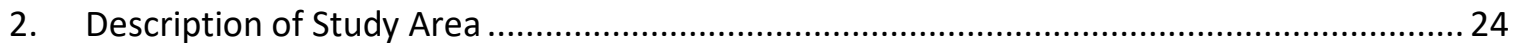

2.1 History of watershed restoration in the Cuenca de la Independencia ............... 28

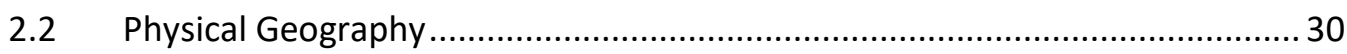

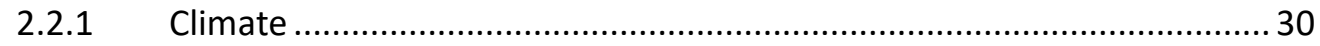

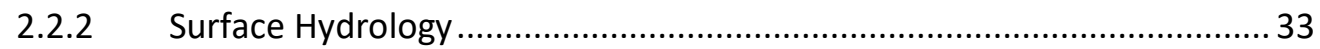

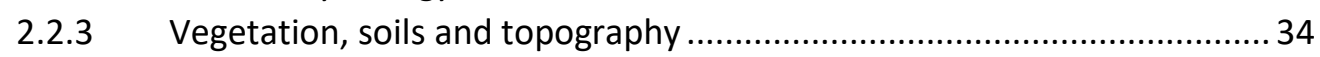

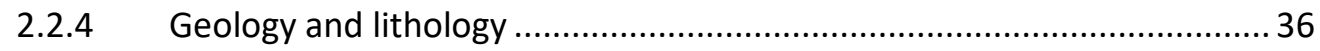

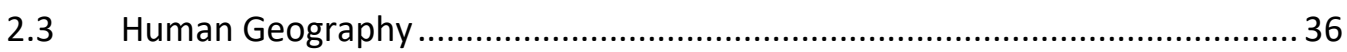

2.3.1 Historical causes of land use and land cover change................................ 36

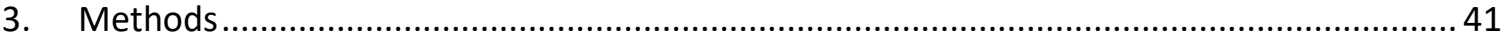

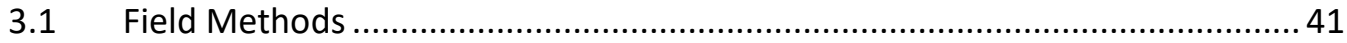

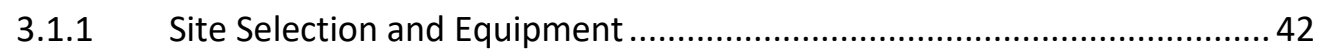

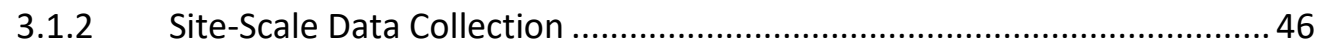

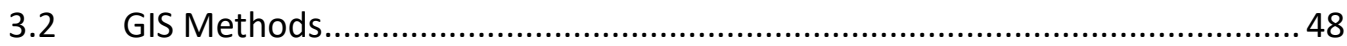

3.2.1 Non-stream power subwatershed variables.......................................... 49

3.2.2 Stream Power Model .............................................................................. 50

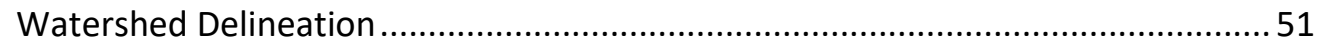

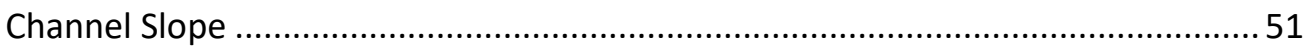

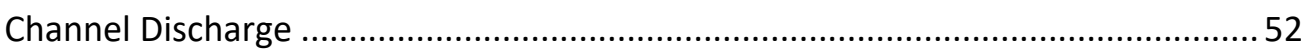

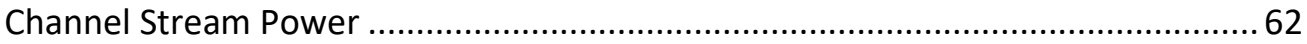

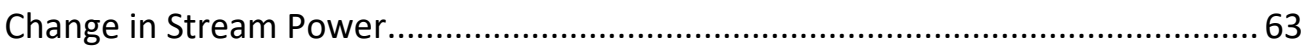

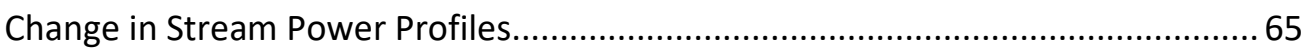

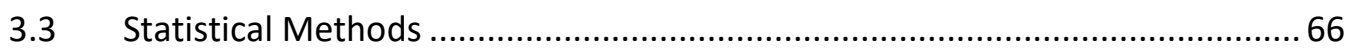

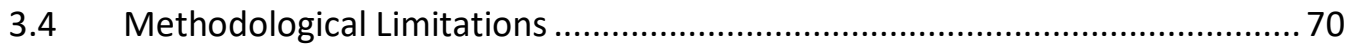

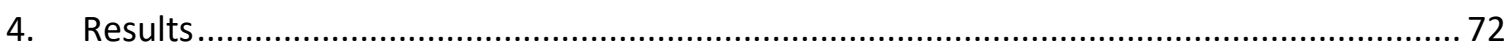




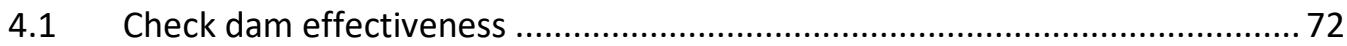

4.2 Controls on check dam effectiveness ........................................................ 75

4.3 Individual Change in Stream Power Profile Analysis and Stream Power Maps 78

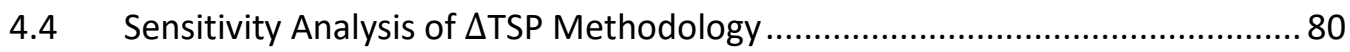

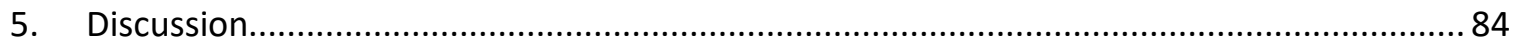

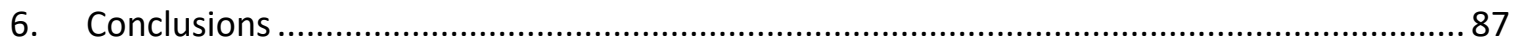

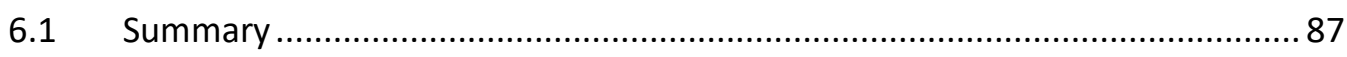

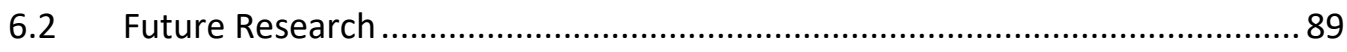

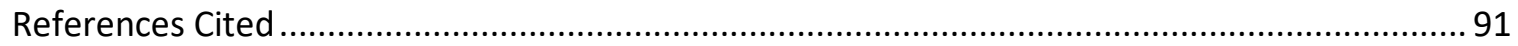

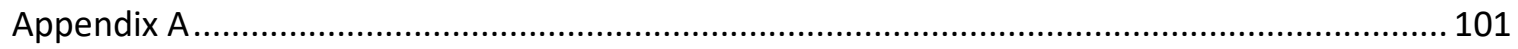

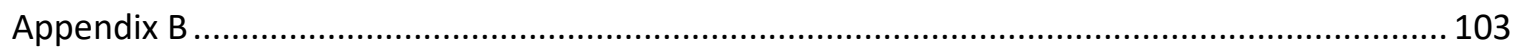

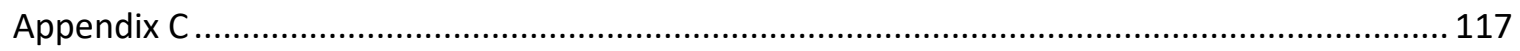




\section{Tables}

Table 1. Details and main findings of check dam studies found in Figure $1 \ldots \ldots \ldots \ldots \ldots \ldots \ldots \ldots . . . . . . . . . . . . .13$

Table 2. Availability of water per capita for México and the State of Guanajuato ..................... 34

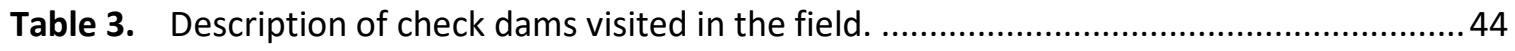

Table 4. GIS-derived variables for each check dam visited.....................................................53

Table 5. Description of gauged watersheds used to calculate the drainage area relationship.. 58

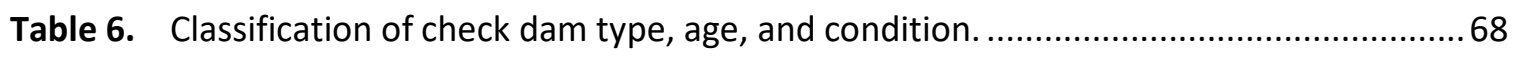

Table 7. Field-derived variables for each check dam visited. ................................................68

Table 8. Spearman's correlation coefficient $r$ between $\mathrm{DsD}_{50}-U_{s} \mathrm{D}_{50}$ (continuous) and different

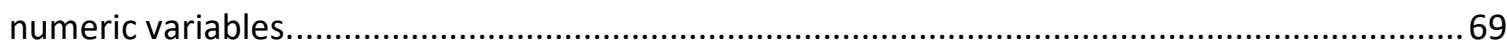

Table 9. Distribution means and Wilcoxon Signed Rank test $P$ values for $\Delta T S P$ derived from

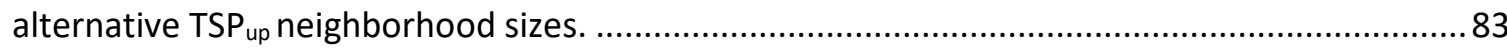




\section{Figures}

Figure 1. Map of sample locations where check dams have been constructed and studied worldwide.

Figure 2. Graphic showing the relationships between basin characteristics and check dam

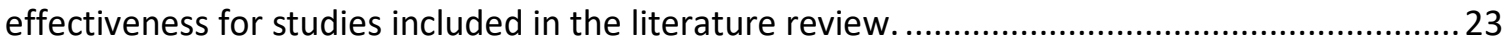

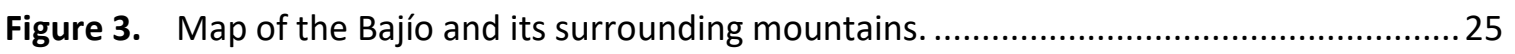

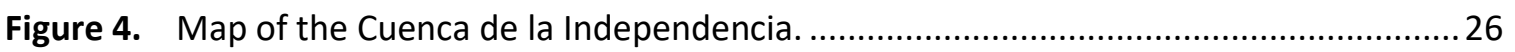

Figure 5. Map showing the locations of the thirteen study subwatersheds...........................2 27

Figure 6. Mean monthly temperature and rainfall for San Miguel de Allende, Guanajuato....... 31

Figure 7. Photos showing the types and conditions of check dams visited in the field. ............45

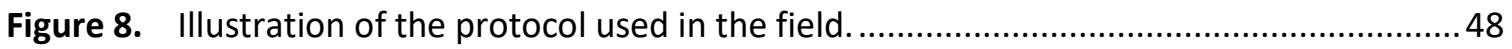

Figure 9. Chart of GIS workflow for calculating spatially explicit total stream power. ..............56

Figure 10. $K$ values and flood frequency distributions for donor gauge sites. ...........................61

Figure 11. Relationship between $Q_{\text {med }}$ and drainage area for donor watersheds......................63

Figure 12. GIS method for calculating TSP local and $\mathrm{TSP}_{\text {up }}$ (from left to right). $\mathrm{TSP}_{\text {up }}$ neighborhood is not to scale.

Figure 13. Cumulative frequency distribution of aggregated particle sizes measured downstream of check dams.

Figure 14. Cumulative frequency distribution of aggregated particle sizes measured upstream of check dams.

Figure 15. Distribution of particle sizes aggregated by order of sample taken for all upstream and downstream transects.

Figure 16. Schematic profile showing the alluvial effect of a check dam.

Figure 17. Plot of the relationship between $\mathrm{DsD}_{50}-\mathrm{UsD}_{50}$ and geomorphic unit as classified by $\Delta$ TSP for all measured check dams.

Figure 18. Plot of the relationship between $\mathrm{DsD}_{50}-\mathrm{UsD}_{50}$ and depositional unit as classified by $\Delta$ TSP for all measured check dams.

Figure 19. Plot of the relationship between $\mathrm{DsD}_{50}-\mathrm{UsD}_{50}$ and Strahler stream order for all measured check dams.

Figure 20. Comparison of TSP values associated with different neighborhood sizes for the Alcocer subwatershed. 


\section{Introduction}

Soil erosion is well-acknowledged as a cause of land degradation throughout the world. In recent decades, as land use changes have become more prevalent, much focus has been directed to hillslope instability at the catchment scale. Gully erosion, in particular, has often been found to be a main source of sediments located downstream from headwaters (Wasson et al. 2002; Krause et al. 2003; de Vente and Poesen 2005). Increased rates of reservoir siltation, enhanced drainage, reduced soil fertility/vegetative cover, accelerated aridification, and changes to rates of groundwater recharge are all impacts associated with severe gully erosion (Eitel, Eberle, and Kuhn 2002; Daba 2002). Yet until recently, there has been relatively little research focused on gully erosion, mainly because it is difficult to study and predict (Valentin, Poesen, and Li 2005). This difficulty stems from heterogeneity among several factors that control gully forming processes-local topography, lithology, pedology, and land use. Precipitation regimes — as characterized by event duration, intensity, and total rainfall also play a role in contributing to gully erosion (DeLong, Johnson, and Whipple 2014).

Physically based distributed hydrological models provide a means for predicting the distribution of spatially heterogeneous variables such as stream flow. The modelled watershed parameters can then be correlated with the occurrence or quantities of geomorphic features/variables (e.g., gullies themselves or structures used to prevent gully formation and growth) to test for linear relationships. Spatial variation in stream power, which is primarily a function of channel gradient and stream discharge, drives erosion and deposition processes and has been found to correlate with gully prevalence and distribution 
(Conoscenti, 2013; Lea and Legleiter, 2016). Of the factors that influence geomorphic change in fluvial systems across time and space, stream power emerges as a particularly important control (Lecce 1997).

Increasing rates of gully erosion have prompted efforts directed toward control and prevention. Several techniques are used (e.g., riparian buffers, vegetation plantings, and check dams), depending upon local physiographic/climatic conditions, access to resources, and overall restoration goals. The present study focuses on check dams, which can take a variety of forms but are generally defined as manmade structures that are intended to "check", or regulate, the speed of concentrated flow. Pervious check dams are composed of a variety of materials_ —including woody debris, dirt, stone, and wire_-and allow for the transmission of water. While reducing channel flow velocities, check dams also serve to: retain sediments that become entrained in flow during runoff-producing events; decrease the erosive force of concentrated runoff; and increase the contact time of surface runoff with upland stream channels, thus potentially increasing groundwater recharge (Murty 1998). These effects can be especially important in ephemeral stream channels, where low frequency/high intensity rainfall from convective storms result in erosive and concentrated flow.

Although check dams are well-accepted and often result in visual validation of their effectiveness (e.g., sediment deposition upstream of structure and higher prevalence of surrounding riparian vegetation), the literature is short on empirical, field-based validation. Furthermore, few studies have inquired into which subwatershed attributes can be linked to check dam effectiveness. The purpose of this study is two-fold: i) to systematically quantify the effectiveness of a sample of check dams located in the upland reaches of the Upper Laja 
River watershed in Guanajuato, México; and ii) to explore the relationship between check dam effectiveness and several subwatershed variables that are estimated or calculated using GIS. Of particular interest is the spatial distribution of stream power along the stream channel of each upland study site.

The research questions and associated null and alternative hypotheses are as follows:

1. How effective are the check dams in the Upper Laja River at retaining sediment that becomes entrained in concentrated flow?

$\mathrm{H}_{0}$ : Check dams are ineffective at retaining sediment that becomes entrained in concentrated flow (i.e. $\mathrm{DsD}_{50}$ and $\mathrm{UsD}_{50}$ are not statistically different $-\mathrm{p}>0.05)$.

$\mathrm{H}_{1}$ : Check dams are effective at retaining sediment that becomes entrained in concentrated flow (i.e. $\mathrm{DsD}_{50}>\mathrm{UsD}_{50}$ and the two distributions are statistically different $-\mathrm{p}<0.05)$.

2. How does change in total stream power influence the effectiveness of check dams in retaining sediment?

$\mathrm{H}_{0}$ : Change in total stream power $(\Delta \mathrm{TSP})$ and $\mathrm{DsD}_{50^{-}} \mathrm{UsD}_{50}$ values are not significantly correlated $(\mathrm{p}>0.05)$.

$\mathrm{H}_{1}$ : Change in total stream power and $\mathrm{DsD}_{50}-\mathrm{UsD}_{50}$ values are significantly correlated $(\mathrm{p}<0.05)$.

\subsection{Land degradation stemming from soil erosion}

The process of soil erosion is a natural geologic phenomenon, resulting in the deposition of fertile soils in the form of alluvial plains and loess plateaus that have supported a majority of the world's agricultural output for millennia (Lal 2003). However, it is now recognized that human involvement has altered the rates of soil erosion compared to those of the geological past (He et al. 2006). UNEP (1986) has estimated that nearly two billion ha of land that were once biologically productive have been irreversibly degraded since 1000 AD. The area of land affected by soil erosion through water is approximately 1094 million 
ha globally, of which 751 million ha are severely eroded (Lal 2003). Within these estimated totals, the amount of land affected by soil erosion suffers from depleted soil fertility, degraded soil structure, and reduced effective rooting depth—while severely eroded land is often rendered biologically unproductive all together.

Land use and land cover (LULC) change is a key factor that has been linked to accelerated rates of erosion in different parts of the world (Yang et al. 2003). Humaninduced modifications to natural vegetation regimes, such as conversion from forest to agriculture, are principle among changes that cause accelerated rates of erosion. Moreover, once land is put into production, management practices play a vital role in soil erosion responses. Lal and Stewart (1990) estimated that approximately 12 million ha of arable land globally are destroyed and abandoned on an annual basis due to unsustainable farming practices. This trend is not unique to recent times, as history provides many examples of land abandonment resulting from soil erosion (Dotterweich 2013). Historical studies show that, during the first half of the $14^{\text {th }}$ century, many villages in Germany were abandoned due, in part, to crop failure and soil degradation caused by soil erosion (Dottertweich 2008). Similarly, gully and badland development in many areas throughout Africa resulted in land abandonment after the introduction of European-style agriculture and land management practices (Showers 2006).

\subsubsection{Control factors of soil erosion}

The process of soil erosion is a primary input into landscape evolution and is largely driven by four geophysical factors: topography, soil type, parent material, and climate. 
Anthropogenic factors, especially in the form of LULC change, have also recently been associated with soil erosion. Other important factors in soil erosion, such as biogeography and hydrologic regime, are treated here as controlled by climatological inputs. Importantly, each of these control factors are influenced to varying degrees by human inputs because each are subject to a unique set of governing processes that proceed according to their own temporal scales. For example, while changes to topography, pedology and lithology are nearly static from an anthropic temporal perspective, climate is proving to be more dynamic and responsive to human activities.

As the present study uses stream power and its relationship to check dam effectiveness, the control factors of topography and climate (runoff discharge) are of particular interest. The relationship between the occurrence and rate of erosion and these two factors are well established. At the global scale, basin erosion rates have been linked to many environmental parameters through bivariate correlation (Portanga and Bierman 2011). Of the parameters used by Portanga and Bierman (2011), higher basin slope gradients, mean elevations, and seismicity were found to have significant positive correlations with higher basin erosion rates; basin slope being most strongly correlated $\left(\mathrm{R}^{2}=0.33\right)$. The dominant role of topography in controlling erosion in mountainous regions is further supported by Aalto et al. (2006) in the Andes range, Montgomery and Brandon (2002) in the Cascade range of Washington (USA), Schaller et al. (2001) in Europe, and Vance et al. (2003) in the Himalaya range.

A parameter of second order in controlling sediment fluxes in mountainous watersheds is that of discharge (a proxy for precipitation), which is a function of climate. Although, broadly speaking, the research suggests weak correlations between runoff regime 
and rates of erosion, some studies have found a significant relationship between the two (Milliman and Syvitski 1992; Gabet et al. 2008). More specifically, rainfall intensity rates seem to have a complex, yet critical influence on sediment flux rates (Assouline and Ben-Hur 2006). High rainfall intensities, particularly when combined with aridity can result in degraded landscapes. Of the nearly $30 \%$ of global land area that is considered semi-arid or arid (FAO), 12\% is either highly or very highly vulnerable to desertification processes (Eswaran, Reich, and Beinroth 1999).

\subsubsection{Soil erosion by water}

There are four primary types of surface erosion caused by water (Wischmeier and Smith 1978). Splash erosion occurs when soil particles become detached due to the impact of raindrops on a soil surface. Sheet erosion refers to the subsequent down-slope movement of detached soil particles by way of sheet flow. The third type of water erosion is linear erosion, in which detached soil particles are transported by concentrated flow. Lastly, mass movement occurs when a collection of soil particles detach from a subsurface soil horizon due to soil saturation and the effects of gravity (FAO 2014). In addition to the four types of surface erosion, subsurface groundwater movement can play a role in hillslope and channel stability. For example, collapsed headcut walls and landslides can occur when preferential flow paths through soil pipes weaken subsurface soil horizons (Fox and Wilson 2010).

\subsubsection{Gully erosion}

Gully erosion most often results from either linear or mass movement erosion; channel incision is a case of the former, while headcut wall and channel bank failures are an example of the latter. Poeson et al. (2003) defines gully erosion as the process whereby 
runoff water accumulates and often recurs in narrow channels and, over short periods, removes the soil from the area to considerable depths. Gully formation is initiated when flow velocity accedes the threshold resistance of a soil material, inducing scouring and causing channel growth. The first stage of channel growth is referred to as a rill, which contains a maximum width of $0.3 \mathrm{~m}$ and a maximum depth of about $0.6 \mathrm{~m}$ (Brice 1966). If channel growth continues, a rill becomes an ephemeral gully, a classic gully, and finally a stream/river channel. It should be noted that this channel erosion evolution represents a continuum, whose classification into separate forms is, to some extent, subjective (Poesen et al. 2003). Classification aside, the general spatial pattern of gully erosion is well understood - headcuts migrate upslope, channels increase in width and depth, and eroded sediments are transported downslope to depositional zones.

The rate at which channel/gully erosion progresses depends on the combination of local control factors and can be empirically measured using both ground-based and airborne techniques. Over the short term (1-10 years), gully head/wall retreat has been estimated by regularly measuring the distance between the edge of the gully head/wall and benchmark pins installed near the gully head/wall (e.g. Vandekerckhove et al. 2001; Oostwoud Wijdenes and Bryan 2001). At smaller spatial scales, several studies have applied photogrammetric techniques to temporally sequential aerial images in order to determine the volume of soil lost to concentrated flow (e.g. Ries and Marzolff 2003). Gesch et al. (2015) used close-range digital photogrammetry to measure geomorphological changes in simulated ephemeral gully surfaces and found the method to provide a highly accurate reconstruction of the experimental surface. 
Whether a result of natural phenomena, human-related changes to land or climate, or a combination of both, high rates of gully erosion can impose unwanted environmental, social and economic consequences on local communities (Stahl 1993; Martínez-Casasnovas and Ramos 2006). For example, farm and rangeland may become fragmented and less productive due to gully channel incision and topsoil erosion. Moreover, the land itself can be lost to headcut migration - a process that results in sediment being transported from upland source to valley bottom. Sediments eroded from gullies are often impounded in reservoirs and dams that are used for flood control, irrigation, or energy generation. Accelerated siltation of these man-made water impoundments is another cost associated with gully erosion (Tamene et al. 2006). Poesen et al. (2003) estimate that gully erosion can represent up to $94 \%$ of total sediment mass transported at the catchment scale, whereas gully channels often occupy less than $5 \%$ of total catchment land area. This disproportionate volume of sediment yield to land area demonstrates the importance of further studying not only gully erosion processes, but the measures that have been taken to mitigate gully erosion formation and progression.

\subsubsection{Check dams in theory and practice}

In both the theoretical and practical realms, check dams have proven to be useful as a method of gully prevention. In essence, a check dam is simply a replica of what is produced naturally through the highly complex interactions of hydrologic and geomorphic processes. Self-organizing step-pool sequences occur in a variety of fluvial settings, ranging from perennial streams in temperate climates to ephemeral streams in semi-arid and hyperarid regions (Wohl and Grodek, 1994; Chin, 1999; Chin and Phillips, 2007). Check dams, like naturally-occurring log steps in forested alpine streams, serve to dissipate the potential 
energy within concentrated flow that would otherwise be used to transport sediment downstream (Marston, 1982; Wilcox et al., 2011). As a consequence, local streamflow velocities are reduced and water surface slopes are decreased on the upstream side of a check dam (Shieh et al., 2007). Among other outcomes, this disruption in streamflow causes the deposition of coarse particulate matter and sediments, provides habitat for aquatic insects, and creates cover in pools and slow water areas (Marcus et al., 2002). Moreover, in stream channels that have undergone human modifications in the form of agriculture, animal grazing or loss of woody riparian vegetation (i.e., natural step-pool formation processes have been compromised), check dams can encourage a return to fluvial equilibrium.

So, if check dams have already been proven to be beneficial, why study them? An important parallel line of inquiry has to do with the geography of a check dam's natural counterpart. In other words, if we can better understand where step-pools naturally occur, we can draw conclusions about where to locate their manmade counterparts. Unfortunately, although some studies have linked the spatial patterns of self-organizing step-pools to variability in channel slope (e.g., Wertz, 1966; Chin, 1999) and channel width (e.g., Chartrand and Whiting, 2000), these observations are scale dependent and cannot be generally applied. As is the case with many phenomena that are driven by stochasticity, the spatial organization of step-pools may necessarily be limited to local characterization.

The longitudinal connectivity of rivers and streams, whether in reference to geomorphic or ecologic processes, is disrupted by natural and anthropogenic inputs. Sediment size distributions can be sampled in undisrupted and disrupted reaches to better understand how natural and human built obstructions to streamflow affect fluvial geomorphic equilibria. Beaver dams are an example of natural obstructions to streamflow 
and have been shown to disrupt sediment size distributions, with free flowing reaches having larger clast sizes than reaches where beaver dams occur (Burchsted and Daniels, 2014). Similarly, man-made dams of all types and sizes cause discontinuity in grain size distributions along stream corridors. Although sampling schemes vary, many authors have quantified this cause and effect relationship through the use of pebble counts taken on dammed and undammed reaches (Baker et. al. 2011; Fencl et. al. 2015). These past studies provide support for the usage of pebble counts (deriving $\mathrm{D}_{50}$ sediment size distributions) in evaluating check dam effectiveness.

\subsection{Restoration through the use of check dams}

The various social, environmental, and economic costs of soil erosion discussed above have resulted in the proliferation of erosion control programs worldwide, especially in countries where steep basin slope and/or monsoonal weather patterns are found. The following sections provide a review of several such programs in various parts of the world (Figure 1 and Table 1), including: the Loess Plateau in China; the highlands of Northern Ethiopia; the Mediterranean environments of Spain and Italy; the Great Basin in the United States; and finally, the focus of this study - the Upper Laja River watershed in the Central Mexican Plateau. As a response to severe water erosion, each of these efforts has, to varying degrees, used the time-honored erosion control method of constructing check dams. Indeed, the Nabataean people of Negev, the Zuni people of North America, and people of the Ming Dynasty in China constructed check dams to divert surface runoff to desired locations and retain soil and water for agricultural purposes (Kedar 1957; Norton et al. 2002; Xiang-Zhou et al. 2004). Although more recently, research has offered new insights into the ecological 
and social benefits of check dams, these often primitive structures continue to provide similar solutions to many people around the world.

\subsubsection{Asia}

Erosion control efforts throughout Asia have included the use of check dams. In the Hathmati watershed of Western India, the government's Soil and Water Conservation Division has constructed a number of check dams for the purposes of erosion reduction and water harvesting. Patel et al. (2015) performed an analysis to identify suitable locations for future check dams using soil type, drainage density, slope, and compound factor as geomorphic parameters. Compound factor, which is a function of several stream network and watershed shape descriptors, was given the highest normalized weight in prioritizing check dam location. Soil type, drainage density, and slope were given lower weightings in the analysis. Their findings indicate that check dams placed at moderate elevations and in densely vegetated areas maximize water and sediment retention potential. In the Shiwaliks region of India, four micro-catchments containing loose rock check dams were surveyed to explore whether lower order, rather than higher order streams are more effective locations for check dam placement. The study concluded that check dams placed in first and second order gullies decreased the catchment's runoff coefficient from $15.5 \%$ to $12.8 \%$, while the overall sediment yield of the catchment was reduced by $20 \%$ during an eight-year period from 2000-2007.

Another notable conclusion was that construction of gully plugs in lower order streams “... did not require any skilled labor or involve huge construction costs" (Sran, Kukal, and Singh 2011, 1326). Mishra, Froebrich, and Gassman (2007) used the Soil and 


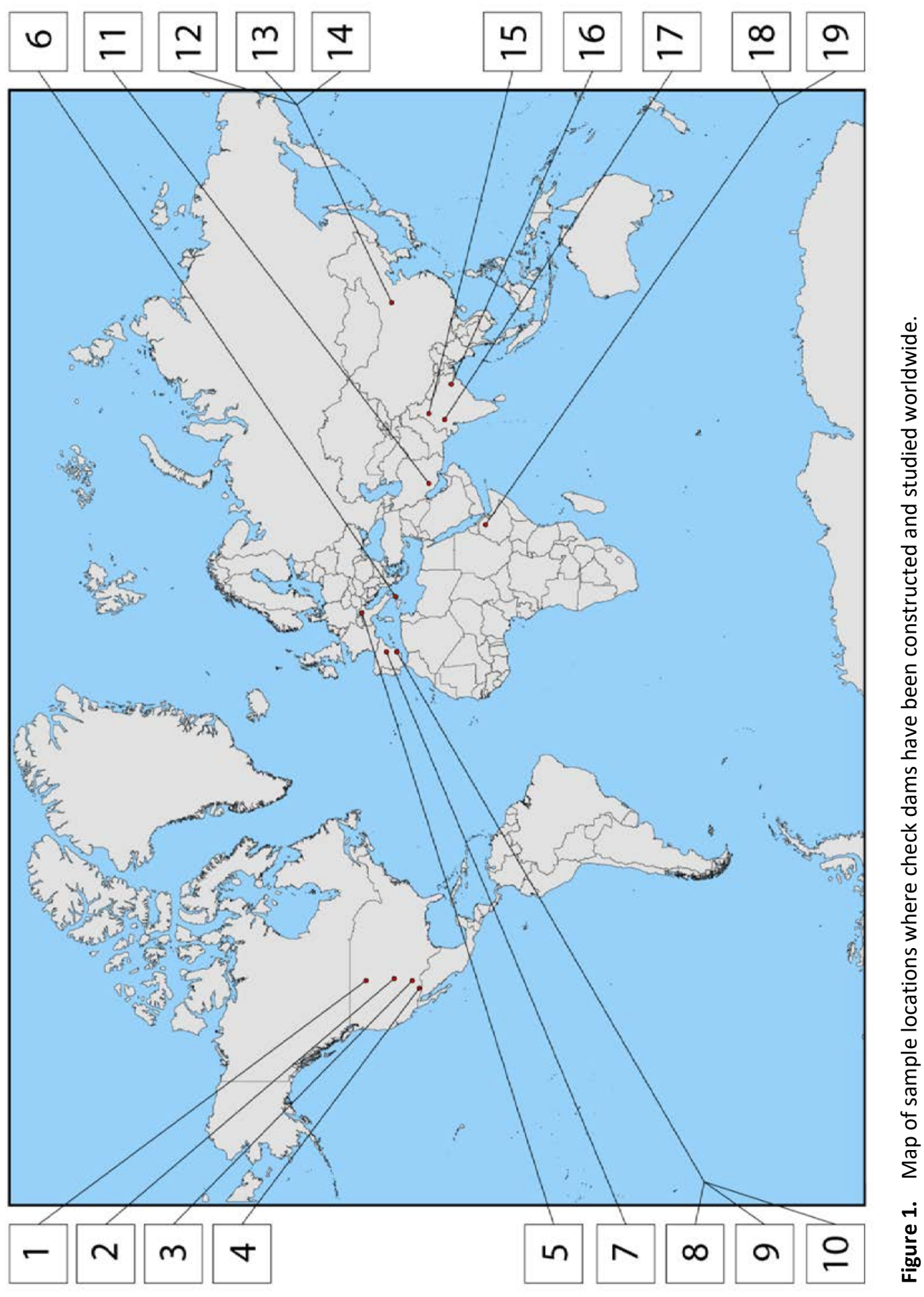




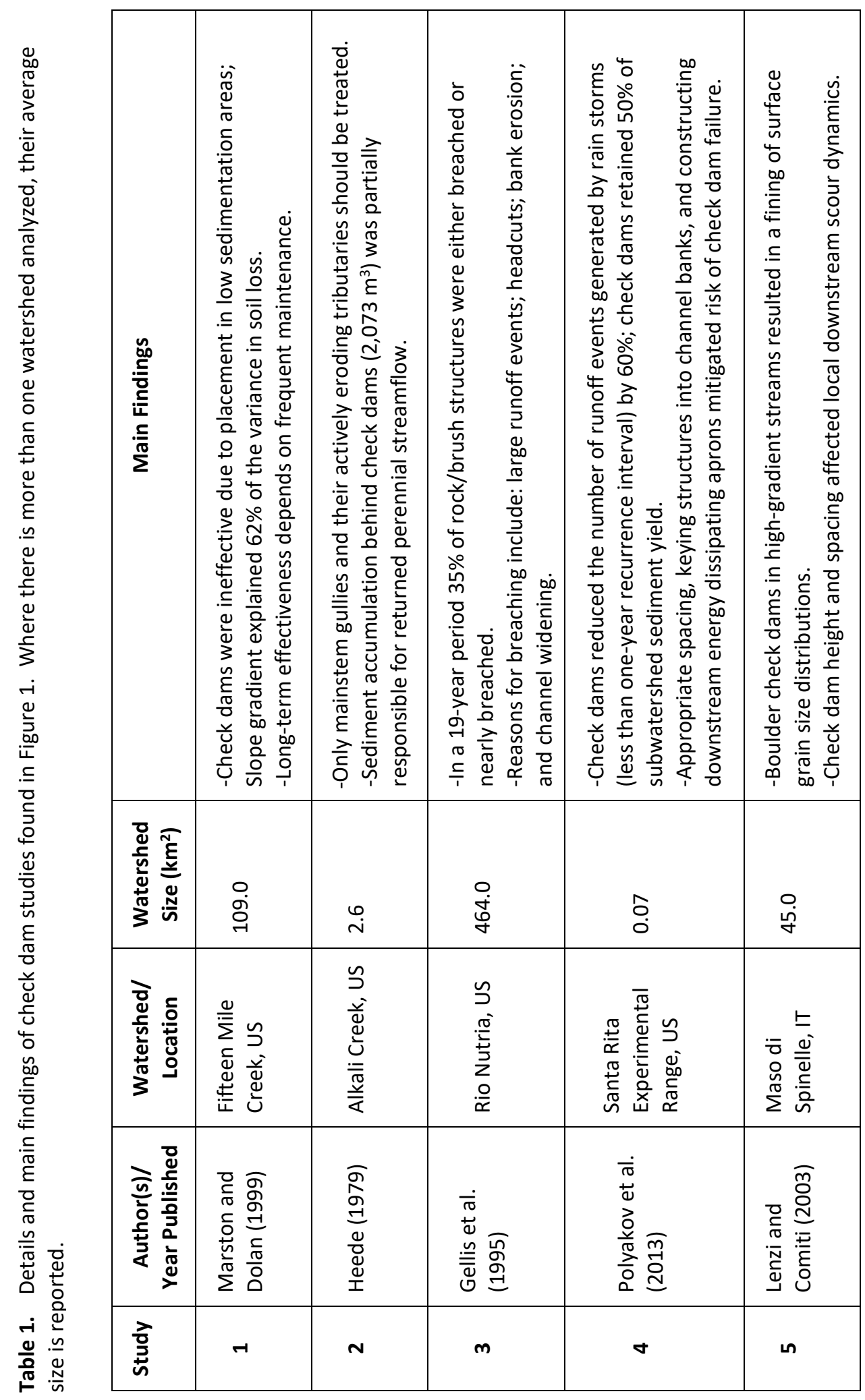




\begin{tabular}{|c|c|c|c|c|c|c|}
\hline 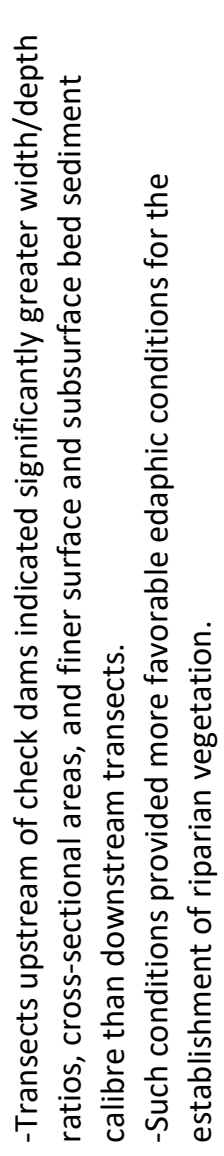 & 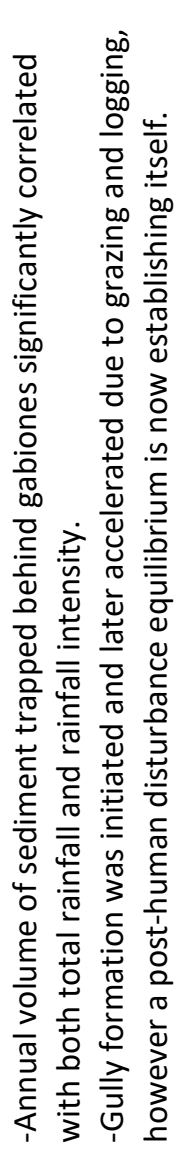 & 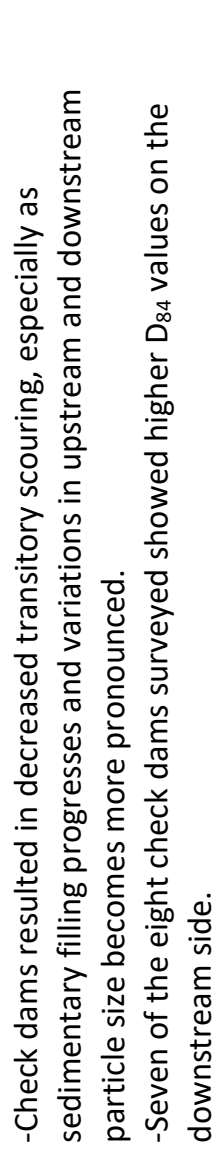 & 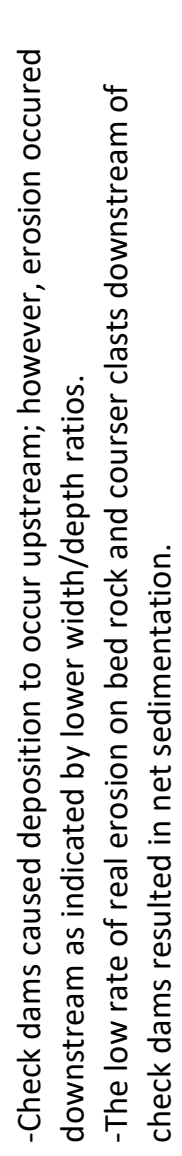 & 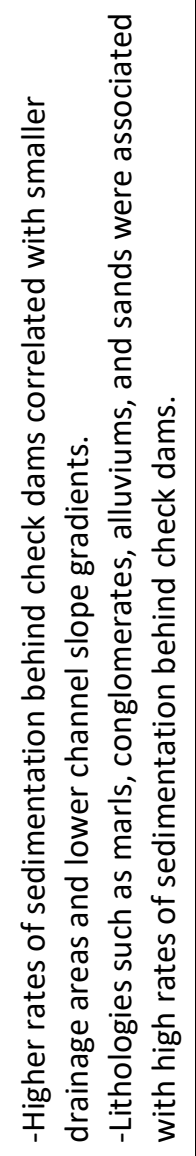 & 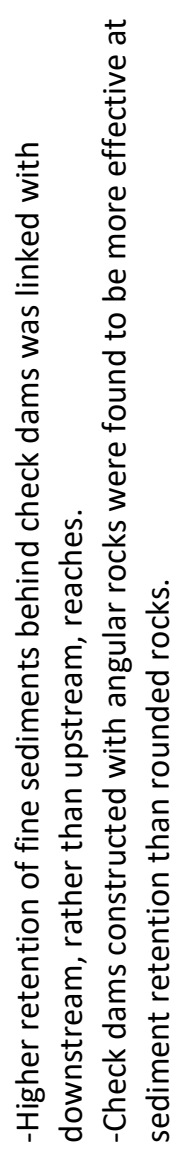 & 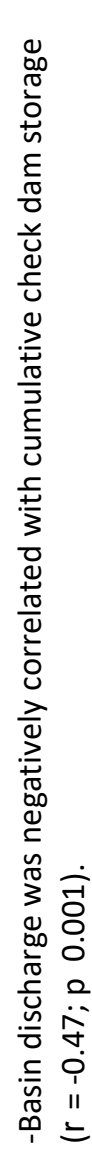 \\
\hline $\begin{array}{l}0 \\
\text { İ } \\
\text { Oे }\end{array}$ & $\underset{\sim}{\stackrel{\sim}{\sim}}$ & ஸे & 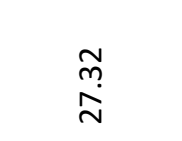 & \begin{tabular}{l}
\multirow{0}{0}{} \\
$\stackrel{0}{\infty}$
\end{tabular} & 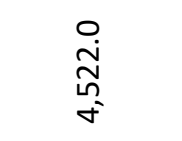 & $\begin{array}{l}\stackrel{0}{\dot{d}} \\
\underset{n}{n} \\
\text { In }\end{array}$ \\
\hline 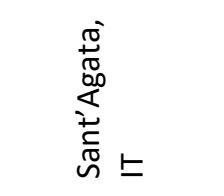 & 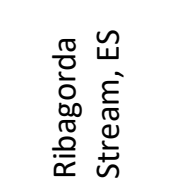 & 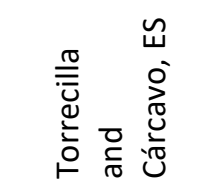 & 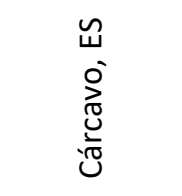 & 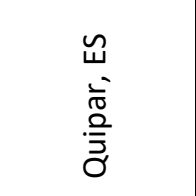 & 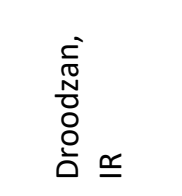 & 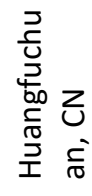 \\
\hline 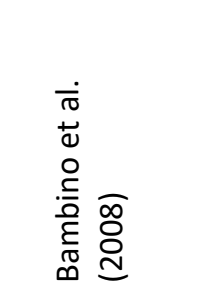 & 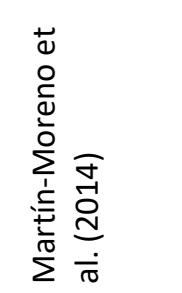 & 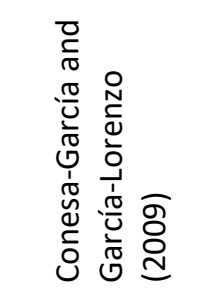 & 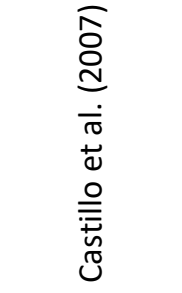 & 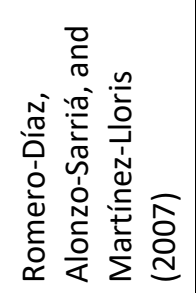 & 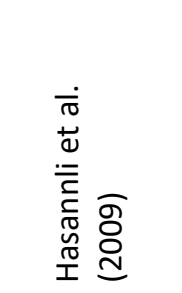 & 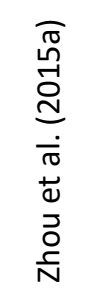 \\
\hline 6 & N & $\infty$ & $\sigma$ & $\Rightarrow$ & $\exists$ & 구 \\
\hline
\end{tabular}




\begin{tabular}{|c|c|c|c|c|c|c|}
\hline 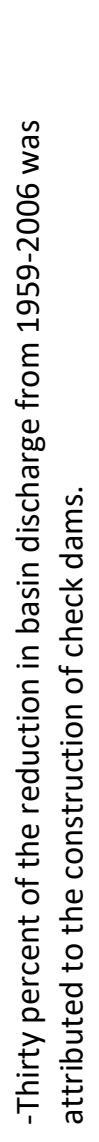 & 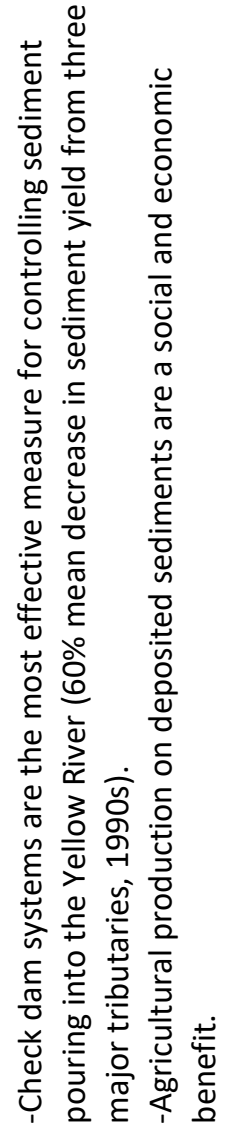 & 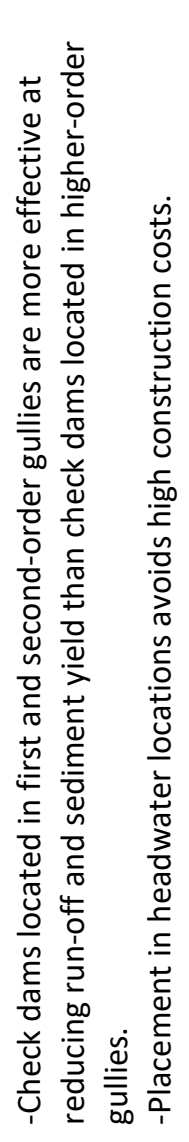 & 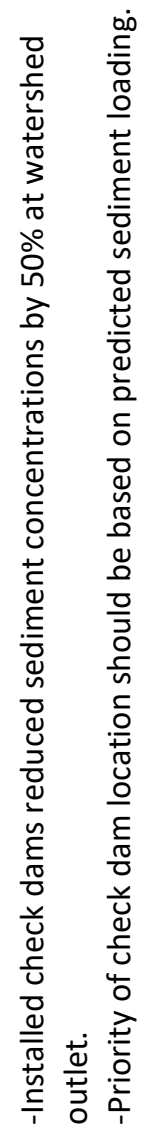 & 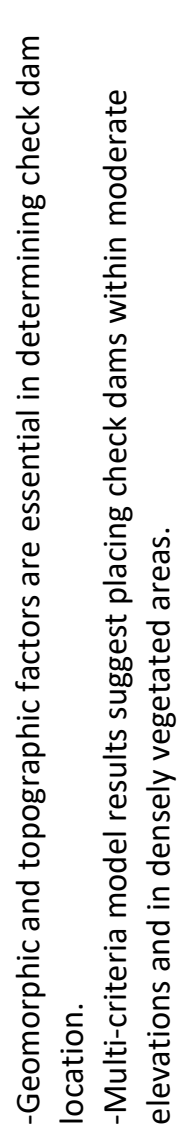 & 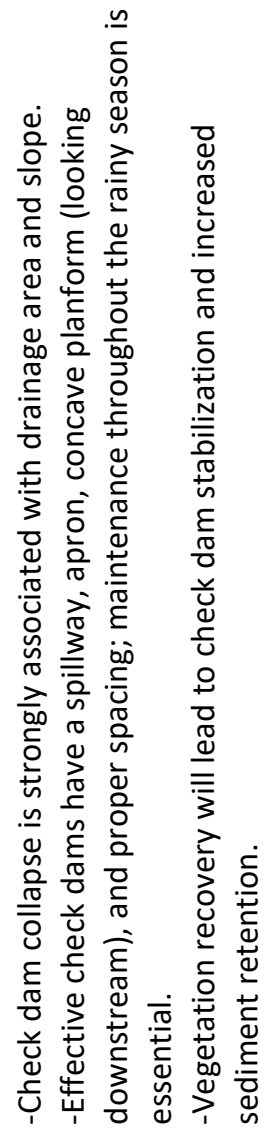 & 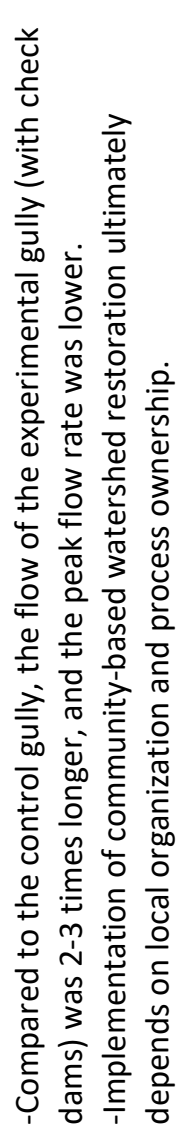 \\
\hline $\begin{array}{l}\stackrel{0}{\dot{d}} \\
\stackrel{\dot{\sim}}{m}\end{array}$ & $\begin{array}{l}0 \\
8 \\
8 \\
\text { đ̇ }\end{array}$ & $\stackrel{\vec{N}}{0}$ & $\begin{array}{l}\text { ڤn } \\
\stackrel{6}{\sigma}\end{array}$ & $\begin{array}{l}0 \\
\dot{0} \\
0 \\
0 \\
-1\end{array}$ & $\stackrel{t}{\circ}$ & $\begin{array}{l}0 \\
\stackrel{0}{\circ}\end{array}$ \\
\hline 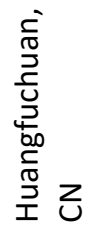 & 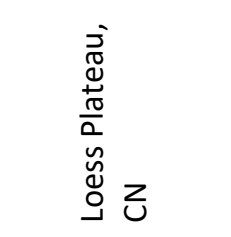 & 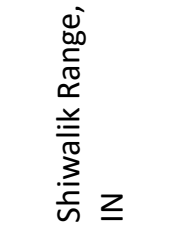 & $\begin{array}{l}\geqq \\
\frac{\pi}{\tilde{D}} \\
\frac{5}{\pi} \\
\infty\end{array}$ & 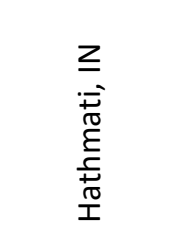 & $\begin{array}{l}5 \\
5 \\
\mathbb{0} \\
0 \\
0\end{array}$ & 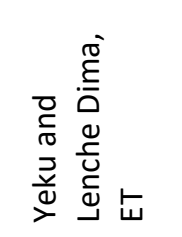 \\
\hline 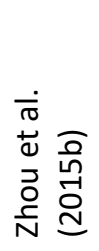 & 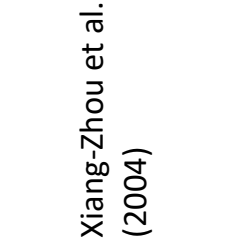 & 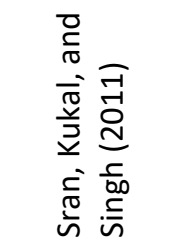 & 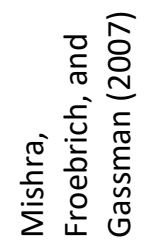 & 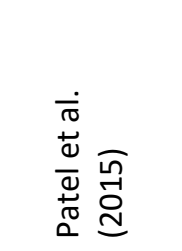 & 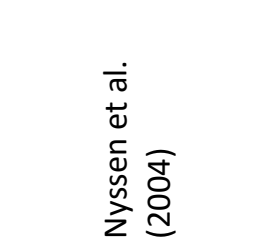 & 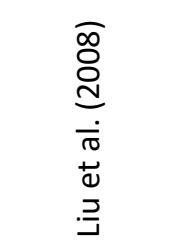 \\
\hline$\stackrel{m}{q}$ & $\underset{ন}{ \pm}$ & உ & $\stackrel{\bullet}{\sim}$ & $\mathcal{F}$ & $\stackrel{\infty}{\rightarrow}$ & 구 \\
\hline
\end{tabular}


Water Assessment Tool (SWAT) to evaluate sediment transport in the Banha watershed in northeast India. Their results indicated that the three installed check dams reduced sediment concentrations by nearly $50 \%$ at the watershed outlet.

Since the 1950s, an ambitious soil and water conservation program has focused on reducing rates of soil erosion in the Loess Plateau of China. As part of this effort, the construction of as many as 163,000 check dams are planned within the region by 2020 (Jin et al. 2012). Zhou et al. (2015a) evaluated surface runoff discharge from two major tributaries of the Middle Yellow River. Mean annual discharge and cumulative check dam storage were found to have a significant negative correlation. Studying the same river system, Zhou et al. (2015b) endeavored to quantitatively attribute the reduction in annual runoff from 19562009 to three causative factors — climate change, check dam construction, and irrigation. It was concluded that on the Huangfuchuan River check dams were responsible for nearly $30 \%$ of total runoff deviation over the study period. Another study that focused on check dams built in China's Loess Plateau contends that the check-dam system is "the most effective measure to control sediment pouring into the Yellow River” (Xiang-zhou et al. 2004, 82). Furthermore, the size of check dams constructed in gullies within the Loess Plateau are often sufficiently large to form fertile farmland from the nutrient rich sediments that are deposited behind each dam over time. This newly created farmland is often used to grow apples and other trees crops.

People in arid parts of Western Asia have also used check dams to combat high rates of erosion. One study, conducted in the Droodzan watershed in Southwest Iran, used grain size distributions taken from above and adjacent to each check dam as a measure of check dam effectiveness. By comparing the distributions associated with dams placed in different 
locations within the watershed, Hasannli et al. (2009) found that the porous check dams constructed in downstream reaches were more effective at retaining fine sediments than those positioned further upstream. Although the differences in distributions are not statistically analyzed, the authors attribute the observed differences to variability in vegetation coverage and check dam construction material (angular vs. rounded rock).

\subsubsection{Africa}

The occurrence of gullies is widespread throughout Africa. In comparing headcut retreat rates in semi-arid landscapes within Spain and Africa, Marzoloff et al. (2007) observed the highest maximum retreat in the West-A frican Sahel (3.16- $\left.9.85 \mathrm{~m} \mathrm{a}^{-1}\right)$. Ethiopia, in particular, suffers from severe land degradation as a result of high rates of water erosion. Nearly half of the country's estimated 60 million ha of agriculturally productive area is highly eroded, while another 14 million ha require rehabilitation, and 2 million ha are considered lost (Mekonen and Tesfahunegn 2011). Both the Tigray and Amhara regions in the northern part of the country have seen the construction of check dams. Nyssen et al. (2004) surveyed 400 loose rock dams within the Northern Ethiopian Highlands and found that $39 \%$ of the check dams inventoried had collapsed after a period of two years. Larger drainage areas and higher slope gradients of the soil surface parallel to the gullies were among the most influential and significant control factors that explained dam failure. Liu et al. (2008) illustrated the effectiveness of check dams constructed with sand bags by comparing hydrographs from two sub-catchments-one with conservation structures and the other without. Although the "control" and "conserved" study plots were not identical, the authors concluded that the results still show the benefits of intervention since the hydrographs associated with two rainfall events (one of identical storm duration, but slightly 
different intensities; the other of slightly different duration, but identical intensities) indicated lower peak flow rates and higher retention times for the conserved micro-catchment.

\subsubsection{Europe}

Several studies in Spain have investigated the functionality of check dams in highyielding sedimentation zones. Martín-Moreno et al. (2014) studied the origin and present geomorphic activity of the Ribagorda sand gully located in the headwaters of the Tagus River in Central Spain. The storage capacity of three check dams, constructed in the 1990s, were filled with sediment by 2008. The heights of these dams were then increased, giving the investigators an opportunity to monitor the gully's sediment yield over a period of six years. The authors calculated the total volume of trapped sediment at $3400 \mathrm{~m}^{3}$, while the mean annual sediment yield and mean annual precipitation over the study period were $114 \mathrm{Mg} \mathrm{ha}{ }^{-1}$ $\mathrm{yr}^{-1}$ and $639 \mathrm{~mm}$, respectively. Annual sediment yield and annual precipitation were statistically significant $\left(\mathrm{R}^{2}=0.74\right)$. The origin of the Ribagorda gully was found to coincide with intensive logging from the $13^{\text {th }}-18^{\text {th }}$ centuries. Conesa-García and García-Lorenzo (2009) studied how transitory scour dynamics (i.e. channel deepening during bankfull flows) are affected by check dams in semi-arid Mediterranean watersheds. The authors concluded that: i) during the 35 years from initial dam construction the difference in bed particle size between upstream and downstream reaches increased nearly fourfold; and ii) there was a generalized reduction in transitory scour values in all cases. Studies conducted on watersheds in eastern Spain have further explored the relationship between rates of erosion and geomorphic variables. Of the parameters linked to higher rates of erosion in ephemeral channels-lithology, basin size, and channel slope show strong relationships. Marl, in particular, has been found to correlate with high rates of erosion, while smaller basin sizes 
and channels with lower gradients are also linked with higher rate of sedimentation behind check dams (Cerdá 2002; Romero-Díaz, Alonso-Sarriá, and Martínez-Lloris 2007). In studying how check dam installation affects erosion-deposition dynamics in the Cárcavo catchment, Castillo et al. (2007) observed increased erosion downstream of check dams and channel stabilization in upstream areas through decreases in longitudinal gradient and water velocities.

Two studies from Italy used bed grain size distributions as a method of quantifying the effects of check dams on stream morphology and vegetation development. Bambino et al. (2008) conducted a geomorphic inventory of four headwater reaches in steep, short, seasonal-flowing mountain streams in Southern Italy. Of the observed data taken from transects located directly upstream and downstream of check dams $\mathrm{D}_{50}$, width/depth ratio, slope, and number of species recorded all showed significant differences. The authors concluded that check dams provide favorable edaphic conditions to support greater riparian species richness. A second study conducted within selected reaches of the $45-\mathrm{km}^{2}$ Maso di Spinelle watershed in Northeastern Italy described the grain size distribution adjustments resulting from a series of boulder check dams. Within a five-year period (1996-2001), there was a fining of grain size distributions within the study reaches. However, since boulders from within the channel were used to construct check dams, "the shift of grain size distribution cannot be seen as a natural evolution pattern" (Lenzi and Comiti 2003, 103). This demonstrates that the origin of construction materials is an important consideration when using differential grain size distributions as an indicator of geomorphic or ecologic change. 


\subsubsection{North America}

Check dams are common archeological features within the semiarid and mountainous landscape of the American Southwest (Doolittle 1985). In more recent times, check dams have been used as sediment/runoff control structures, and a handful of studies have endeavored to analyze their functionality. Polyakov et al. (2014) collected data on runoff and sediment volumes for two ephemeral watersheds (4 and 3.1 ha) in Arizona containing a total of 37 check dams. The authors observed that: i) although runoff from events associated with recurrence intervals of two years or more was unaffected by the presence of check dams, a smaller percentage of low magnitude rainfall events $(<$ one-year recurrence interval) produced runoff; and ii) the post-construction rate of sediment retention was over $50 \%$ of total sediment yield. They concluded that the depositional areas upstream of check dams can serve as starting points for watershed restoration due to increased infiltration and accumulation of organic material.

In response to increased arroyo cutting and gullying in the American Southwest during the late $19^{\text {th }}$ and early $20^{\text {th }}$ centuries, the United States government sponsored numerous erosion control projects, such as those carried out by the Civilian Conservation Corps. (CCC). Gellis et al. (1995) conducted a sample survey of one such project-70 earth, rock or brush structures constructed within the Zuni Reservation in New Mexico. Of the 23 rock and brush structures built in 1976, 22\% were either breached or flanked, while $65 \%$ were observed to be in good condition. A primary factor attributed to check dam success was appropriate spacing “... where each structure is located at the upstream toe of the sediment deposited behind the next downstream structure (Heede 1976). Several factors are listed as reasons for failure including: large runoff events; headcuts; and bank erosion or 
channel widening around the rock and brush structures. The latter can result from increased sinuosity that is caused by a decrease in channel gradient (Gellis et al. 1995).

Relatively high sediment yields in the Fifteenmile Creek watershed of Wyoming's Bighorn River resulted in the creation of an erosion control program during the 1960 s. Marston and Dolan (1999) evaluated the effectiveness of various sediment control structures in relation to spatial patterns of soil erosion within the study catchment. The authors' findings indicate that rates of soil loss varied significantly with slope, vegetation cover, and soil texture- $62 \%$ of total soil loss originated from $8.5 \%$ of the drainage area (predominantly badland topography), and 30\% of the drainage area (low relief and higher density of vegetation cover) contributed $5.5 \%$ of the total soil loss. Because many of the control structures were located in areas of low sedimentation, they were found to be nearly obsolete.

Heede (1979) compared a restored watershed (Alkali Creek in western Colorado) to surrounding watersheds and reached several notable conclusions. Check dam systems aided by grazing exclosures and vegetation plantings were found to have stabilized treated gullies (relative to non-treated gullies) as evidenced by: i) decreases in gully depth and stabilization of gully banks; ii) renewed perennial stream flow and increased infiltration; and iii) a more than $90 \%$ reduction in downstream sediment loads. During the treatment and evaluation period, precipitation rates were found to be statistically normal.

\subsubsection{Summary of Check Dam Studies}

All of the studies reviewed in section 1.2 inquired about: check dam effectiveness; the effects that check dams have on hydrologic, geomorphic, or ecologic function within the stream channel; or optimal check dam location. For the studies reviewed, Figure 2 provides 
an overall summary of how geographic positioning (represented by continentality) and climatic setting (represented by average rainfall intensity) is related to the general effectiveness of check dams within the study area. Basin size is also shown in Figure 2. Due to the diversity of approaches used to quantify/qualify the effectiveness of check dams, specific trends are difficult to identify. However, it does appear that there is a slight correlation between smaller watershed sizes and more effective check dams. Similarly, higher rainfall intensities may have a stronger link to more effective check dams than lower rainfall intensities. Continentality, on the other hand, does not seem to have an effect on check dam effectiveness.

Within the studies found in this analysis, there is much diversity among the watershed variables or basin characteristics that are used in relation to check dam function. Importantly, although many of the studies link different watershed variables to check dam effectiveness or location, none employed stream power as a possible explanation for check dam effectiveness. 

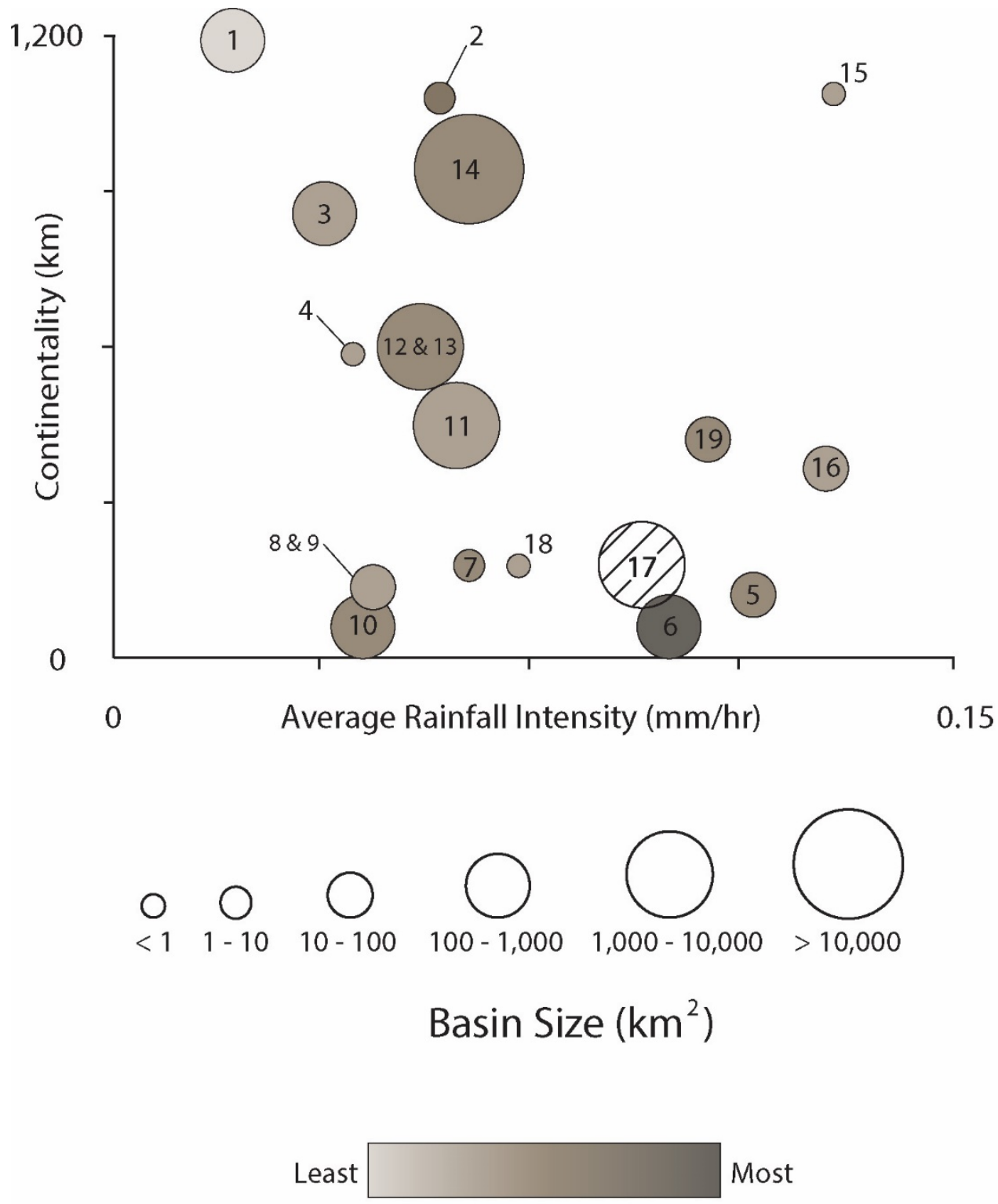

\section{Check Dam Effectiveness}

$\bigotimes$ Check dam effectiveness not measured

Figure 2. Graphic showing the relationships between basin characteristics and check dam effectiveness for studies included in the literature review. See Figure 1 for study numbers. Continentality is measured by taking the Euclidinan distance from the ocean; Average rainfall intensity is measured by averaging 18 years (1998-2015) of monthly mean rainfall intensity values from NASA's TRMM satellite (TRMM, 2016). 


\section{Description of Study Area}

Three principal spatial units are referenced in the physical and human geographical descriptions that follow. The first, and smallest in scale, is "el Bajio" (the lowlands), hereafter referred to as the Bajío. The Bajío represents an area of approximately $26,000 \mathrm{~km}^{2}$, and encompasses parts of four states in Central México—Guanajuato, Jalisco, Michoacán, and Querétaro (Figure 3) (Chambers and Momsen 2007). Known as the breadbasket of México, this area is characterized by open, flat valleys interrupted by mountains with more than 400,000 ha of high-quality irrigated land (Marañón 2006). The nearly 300-meter deep alluvial and lacustrine valley fill in the region is a result of ancient lakebeds formed by the disruption of drainage patterns by volcanic activity beginning in the Cretaceous period (Murphy 1986). While the Bajío has no clear physical boundaries, Southern and Central Guanajuato make up the core of the region.

The second spatial unit of interest, the Upper Laja River watershed (alternatively known as the Cuenca de la Independencia or CI), is a watershed located just north of the Bajío. The CI has a surface area of $6,840 \mathrm{~km}^{2}$ and is found between the parallels of $20^{\circ} 50^{\prime}$ $15^{\prime \prime}$ and $21^{\circ} 32^{\prime} 42^{\prime \prime} \mathrm{N}$ and the meridians of $100^{\circ} 11^{\prime} 23^{\prime \prime}$ and $101^{\circ} 31^{\prime} 33^{\prime \prime} \mathrm{W}$ (Figure 4).

The third spatial unit of study is comprised of nine distinct subwatersheds located at the southern boundary of the CI near the city of San Miguel de Allende in the state of Guanajuato, México (Figure 5). The average size of nine subwatersheds is $.5 \mathrm{~km}^{2}$. 


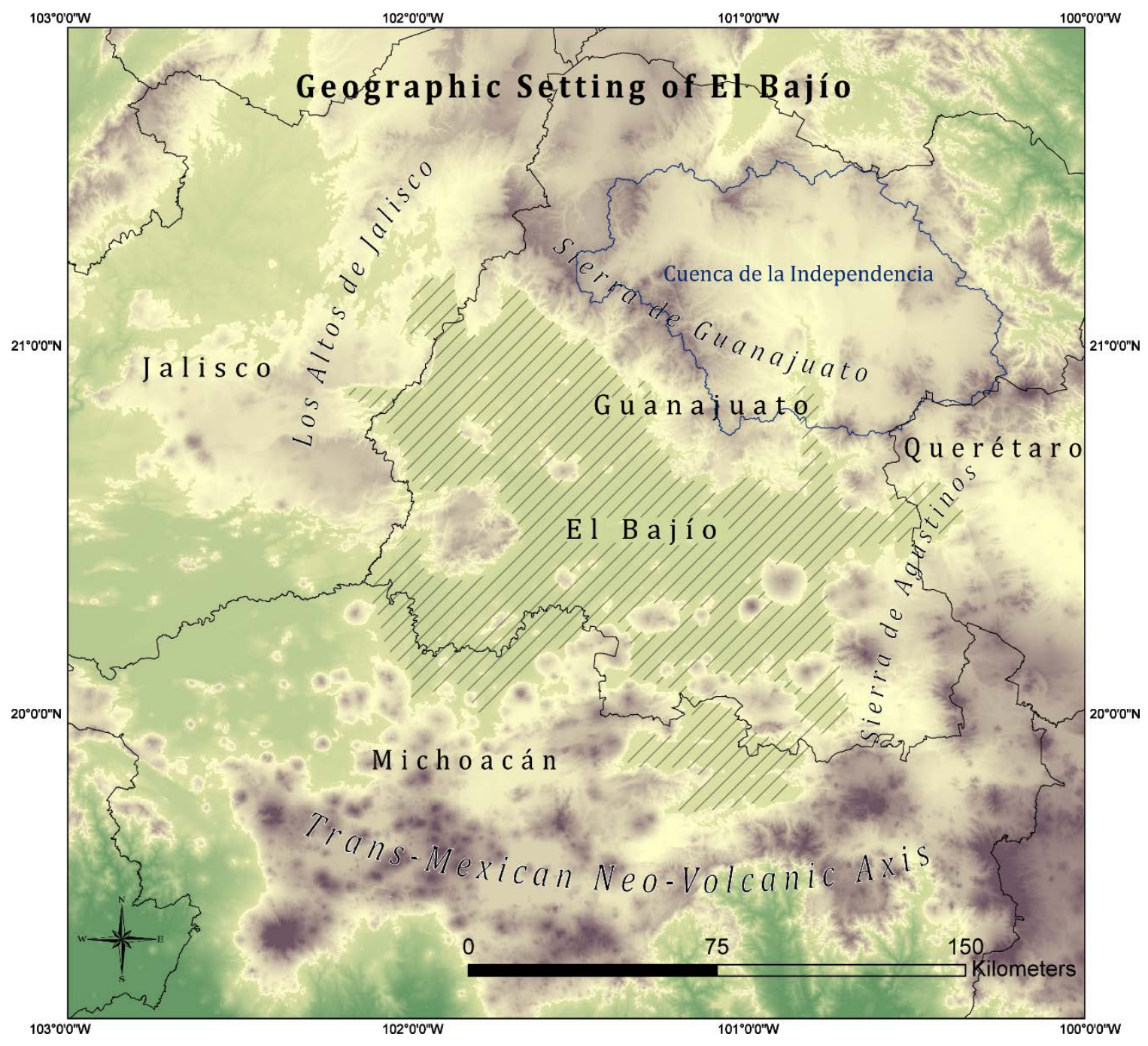

Figure 3. Map of the Bajío and its surrounding mountains. 


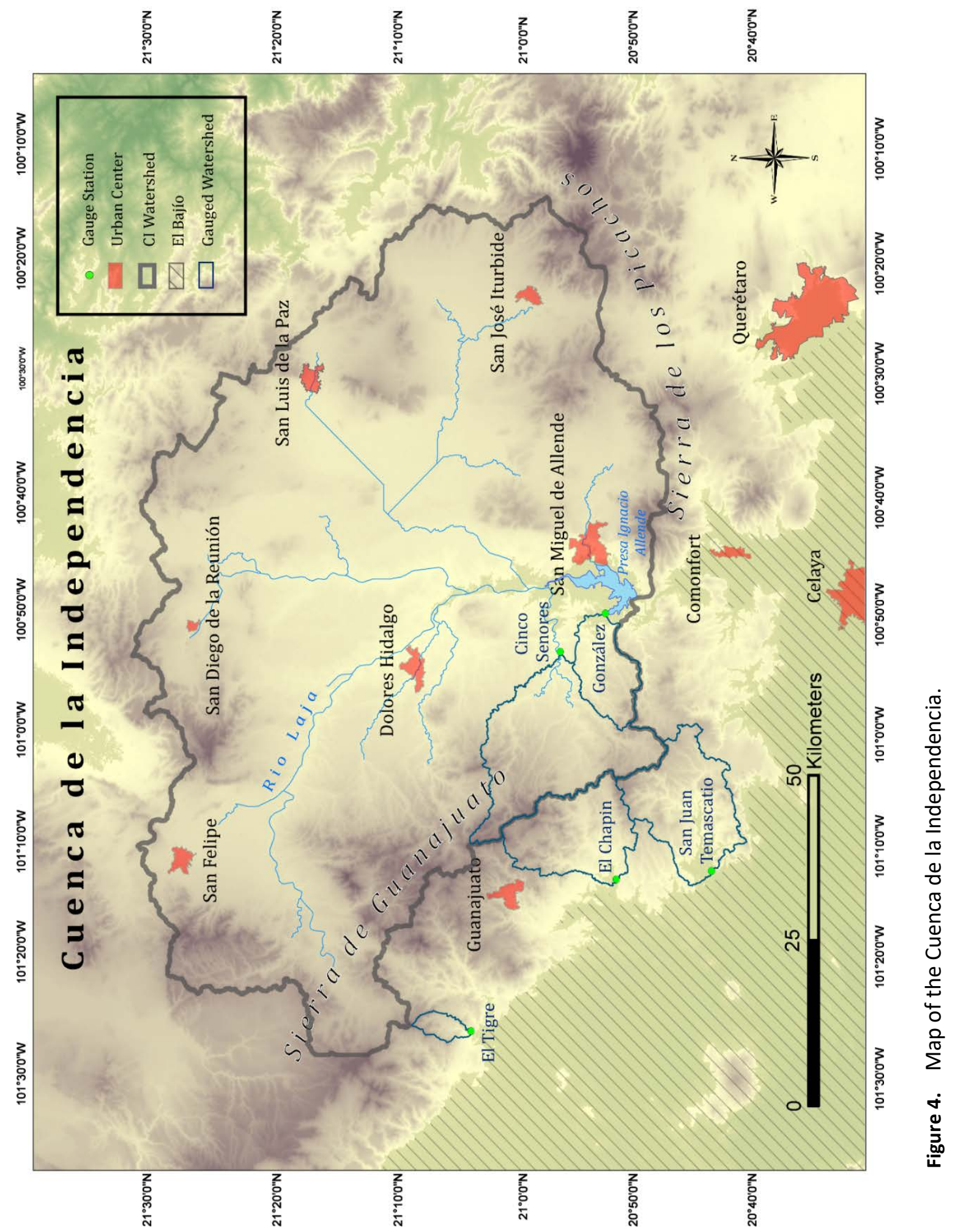




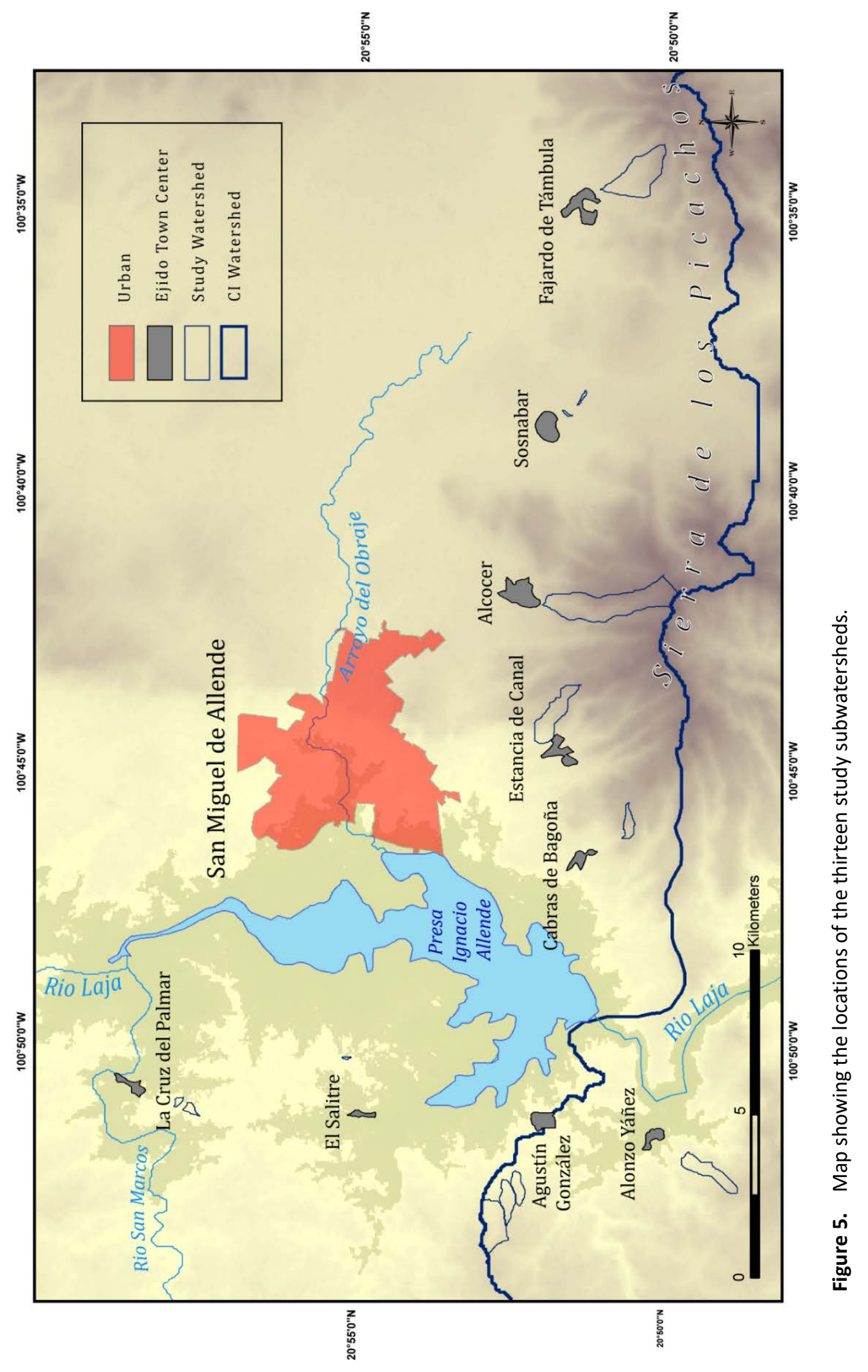




\subsection{History of watershed restoration in the Cuenca de la Independencia}

The watershed restoration program in the $\mathrm{CI}$ is a response to the degraded condition of many areas within the Laja watershed; gullying and badland development can be observed in several ejidos. The program itself is the result of a partnership between non-profits, governmental entities, private foundations, and many different landowners (much of the land in need of rehabilitation is under a patchwork of ejidal ownership). The ejidal system is a legacy of agrarian popular uprising within México and provides land for communal farming.

Of particular importance to this organizational network is Salvemos al Río Laja (SRL), a non-profit organization based in San Miguel de Allende, México. Founded in 1998, the mission of SRL is to organize and facilitate watershed restoration projects within the CI. Salvemos al Río Laja has served as a liaison between the different funding sources-Mexican government agencies (e.g., Comisión Nacional del Agua [CONAGUA], Comisión Nacional Forestal [CONAFOR], and Secretaria de Medio Ambiante y Recursos Naturales [SEMARNAT]), U.S. government agencies (e.g., U.S. Agency of International Development [USAID]), and private foundations (e.g., Fondo Mexicano para la Conservación de la Naturaleza [FMCN], and Ecosystem Sciences Foundation [ESF])—and ejido leadership, who then distributes the funding to program participants in exchange for the completion of watershed restoration projects.

Program goals include economic, social, and environmental components. Due to impoverishment and lack of job opportunities, ejidal inhabitants often require cash payments 
in order to complete watershed restoration projects. These cash payments are reinvested in the local economy through the purchase of food, medicine, and school supplies. Job opportunities through watershed restoration programs also serve to bolster social capital in a variety of ways. One such way is that they offer viable alternatives to ejido members who are otherwise forced to migrate in order to support their families. More generally, and as stated by one ejido leader, "the maintenance of land means the maintenance of people" (Schreiber 2014 , 4). A recent survey of ejido members indicates that $92 \%$ of respondents noted ecological benefits to their land as a result of watershed restoration projects (Schreiber 2014). Restored ecological functionality to land, whether real or perceived, provides real benefits to those who live off of the land.

Of the many types of restoration treatments that have been used within the CI, check dams-largely in the form of loose rock-are most prevalent. Since 2001, SRL has helped facilitate the construction of over 12,300 rock check dams (ESF 2013). To a lesser extent, gabiones (rock check dams enclosed with wire), and check dams constructed with woody debris can be found within the CI. As part of the wider watershed rehabilitation effort, these various check dams are intended to control high rates of soil erosion often in the form of gully erosion. The severity of gully erosion varies from subwatershed to subwatershed, but was evident in the majority of sites visited in the field. 


\subsection{Physical Geography}

\subsubsection{Climate}

According to the Köppen-Geiger Climate Classification System, the majority of the state of Guanajuato is considered BSh, or semi-arid to arid steppe with hot arid temperatures (Garcia, 1964). Guanajuato lies between two distinct climate zones: to the west along the Sierra Madre Occidental is an area dominated by summer monsoons and winter drought; to the east along the Sierra Madre Oriental, the Gulf of México provides winter frontal systems in addition to summer precipitation (Barrett and Esquivel Longoria 2013). Guanajuato is also situated between two zones that are affected differently by El Niño-Southern Oscillation (ENSO). Summer precipitation in southern and eastern México and the Pacific Coast of Central America is affected by phase changes in ENSO (Peralta-Hernández, Balling Jr., and Barba-Martínez 2009), while areas around and to the north of Guanajuato have experienced little co-variability with alternative El Niño and La Niña years (Magaña et al. 2003).

Central Guanajuato is characterized by a semi-arid monsoonal climate, with $90 \%$ of the annual $600 \mathrm{~mm}$ of precipitation falling between the months of May and October (Figure 6). These summertime rains are largely a function of the interaction between local variation in topography and the atmospheric circulation cells associated with the North American Monsoon (Douglas, Maddox, and Howard 1993). The Sierra Madre Oriental to the east, Baja California to the west, and the Sierra Nevada and Rocky Mountains to the north provide the general boundaries for the development and occurrence of the NAM (Ropelewski et al. 2005). These landforms not only channel and block the low-level atmospheric moisture 
supplied by the Pacific Ocean, but also promote atmospheric instability through adiabatic heating and cooling. Deep convection causes thunder storms to form and release their energy in a distinct diurnal pattern—lightning and precipitation often occur in the late afternoon, while early morning to midday are usually cloudless.

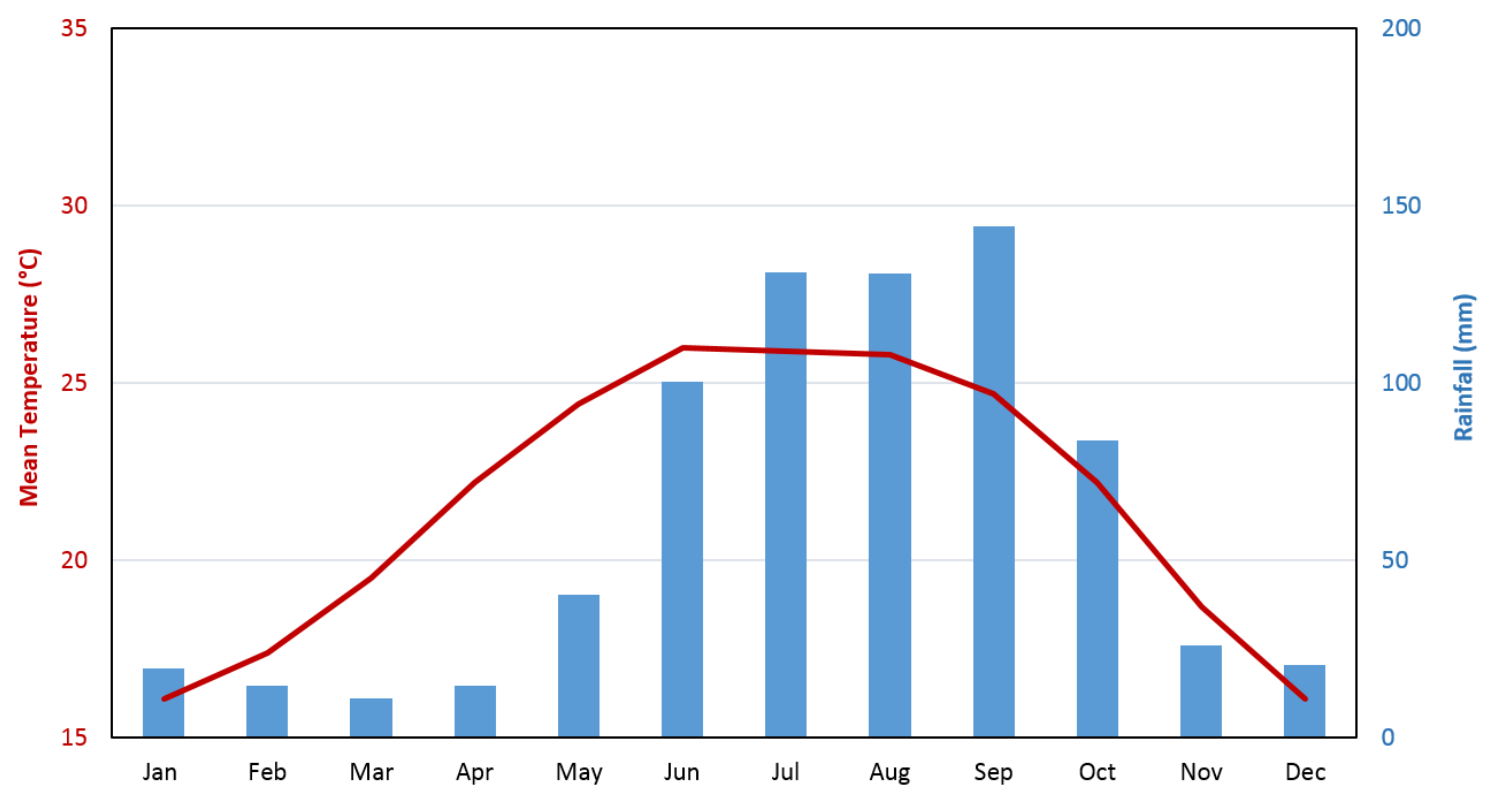

Figure 6. Mean monthly temperature and rainfall for San Miguel de Allende, Guanajuato. Source: World Bank Climate Change Knowledge Portal.

Other influences on the rainfall patterns associated with the NAM include tropical easterly waves originating from north Africa, the North Atlantic subtropical high, and occasional tropical storms originating in the Gulf of México (Ropelewski et al. 2005; Novo and Raga 2013). In general, however, there is agreement that the majority of NAM moisture is derived from the eastern tropical Pacific Ocean and the Gulf of California. The sea surface temperatures (SST) particularly in the Gulf of California have been to found to correlate to NAM rainfall (Mitchell et al. 2002). 
Although rainfall intensity data at high temporal resolutions (i.e., $\mathrm{mm} \mathrm{h}^{-1}$ ) are unavailable for many parts of the world, estimates can be made using the $\mathrm{K}$ parameter, which is used to determine the amount of hourly rainfall for a location given that location's maximum daily rainfall data. Short duration rainfall of high intensity $(K>12)$ implies high runoff and is characteristic of arid to semi-arid regions, whereas longer duration rainfall $(\mathrm{K} \sim 8)$ is associated with humid regions (Ferrer-Polo 1993; Témez 1987). The K parameter for Presa Ignacio Allende has been estimated at 13.07 (Manzano-Agugliaro et al. 2015). This higher $\mathrm{K}$ parameter is validated by the extreme precipitation readings from local meteorological stations. Maximum daily rainfall values from 1963-2012 for Cinco Senores, La Begona, and San Miguel de Allende stations are $83 \mathrm{~mm}, 98.5 \mathrm{~mm}$, and $123 \mathrm{~mm}$, respectively (SMN 2015).

Mean annual temperatures in central Guanajuato range from $14^{\circ} \mathrm{C}$ in the highlands (near 2,900 meters above sea level [m.a.s.l.]) to nearly $20^{\circ} \mathrm{C}$ in the valleys (near 1,700 m.a.s.l.). The average annual maximum temperature from the three closest gauging stations to the subwatersheds of interest is $26.3^{\circ} \mathrm{C}$, while the average minimum temperature is $10.2^{\circ} \mathrm{C}$ (SMN 2015). Pan evaporation, as measured by the Servicio Meteorológico Nacional (SMN) of the Mexican Ministry of Environment and Natural Resources (SEMARNAT) is highest in the late spring and summer months due to higher surface air temperatures and greater precipitation. Average daily pan evaporation taken from the three meteorological stations nearest San Miguel de Allende is approximately $5.1 \mathrm{~mm}$ day $^{-1}$ (SMN 2015), while potential evaporation in parts of Guanajuato can exceed 1,500 mm year ${ }^{-1}$ (Barrett and Esquivel Longoria 2013). 


\subsubsection{Surface Hydrology}

The CI represents approximately $13 \%$ of the drainage area that makes up the largest and most important macro basin within México-the Lerma-Chapala Basin. With an historic annual surface runoff of over $6,000 \mathrm{~mm}^{3}$, the Lerma river supplies municipal, industrial and agricultural water to some 17 million people, or 15\% of the Mexican population (Acosta and Montero Martínez 2014). The Upper portion of the Laja River, encompassing a majority of northern Guanajuato, drains into the Ignacio Allende Reservoir and covers a surface area of approximately $7,016 \mathrm{~km}^{2}$ (Torres-Benites et al. 2005). The average annual discharge at the outlet of the reservoir is approximately $258 \mathrm{~mm}^{3}$ (CNA 1997).

Within the CI, the Laja River is the only perennial stream, with its main tributariesArrastres, Dolores, San Marcos, the Plan, the Carrizal, and Bocas-all flowing intermittently, and its headwater stream systems flowing ephemerally. Rainfall is the primary contribution to surface runoff, although groundwater discharge in various forms does occur to a limited extent. Evidence indicates a total of 201 springs once existed in and around the CI, but that the number of active springs has decreased in recent years. As of 2005, 44 springs were observed with permanent discharge, 91 remained active during the rainy season, and the remaining 66 have dried up entirely (Navarro de León, Gárfias-Soliz, and Mahlknecht 2005).

Since the arrival of the Spaniards in the $16^{\text {th }}$ century the region's hydrology has been modified by the construction of surface water diversions and dams and the drilling of over 2,500 deep wells (Maganda 2003; Navarro de León, Gárfias-Soliz, and Mahlknecht 2005). Moderate to high population growth rates (1.24\% average from 1940-2010), coupled with aggressive agricultural and industrial development policies, have resulted in groundwater 
overexploitation and reduced water availability per capita in the State of Guanajuato (INEGI, 2015)(Table 2).

Table 2. Availability of water per capita for México and the State of Guanajuato , 1970-2000 $\left(\mathrm{m}^{3} /\right.$ person/year). (CEAG, 1999)

\begin{tabular}{lrrrr}
\hline Year & 1970 & 1980 & 1990 & $\mathbf{2 0 0 0}$ \\
\hline México & 8502 & 6133 & 5046 & 4067 \\
Guanajuato & 1538 & 1161 & 877 & 749 \\
\hline
\end{tabular}

There are over a dozen reservoirs along the main stem of the Laja River and many smaller impoundments along its tributaries. Built in 1968, Presa Ignacio Allende is located $124 \mathrm{~km}$ from the headwaters. With a capacity of $180 \mathrm{Mm}^{3}$, Presa Ignacio Allende is the largest impoundment within the CI and provides irrigation to some 18,000 ha (MercadoSilva et al. 2009; Wester et al. 2009).

\subsubsection{Vegetation, soils and topography}

Guanajuato sits between two distinct, large-scale ecoregions: to the north is the Madrean, which extends from Central México to the southwestern United States; to the south is the Caribbean, which covers southern Florida, southern México, and the rest of Central America. The Madrean ecoregion includes steppe, arid desert, and highland-type plant associations, while the Caribbean ecoregion largely consists of moist tropical plant communities. From north to south, the Madrean ecoregion is subdivided into the Great Basin, Californian, Sonoran and Mexican Highland (Altiplanicie Mexicana) subregions. The $\mathrm{CI}$ is located at the southern edge of the Mexican Highlands and holds a diversity of plant communities that are generally distributed along an elevation-based gradient. Xerophytic associations, such as those found in the Cactaceae family of plants, are common in lower 
elevations (1,850-2,250 m.a.s.l.), while pine-oak forests become dominant at higher elevations.

México is ranked among the most biodiverse countries in the world, with approximately 2,800 genera of vascular plants recorded (Villasenor 2004). Although less diverse than some Mexican states (e.g. Chiapas, Oaxaca, and Veracruz), Guanajuato contains a high level of floristic diversity. For example, in the Poaceae family alone, Guanajuato contains 157 species, of which 19\% are endemic (Dávila-Aranda, Lira-Saade, and ValdésReyna 2004). Within the municipality of San Jose Iturbide, which makes up nearly $10 \%$ of the land area of the CI, 661 species of vascular plants have been recorded, $96 \%$ of which are of the phylum Angiospermae and 4\% of the phyla Gynospermae or Pteradophyta (Gutiérrez and Solano 2014).

The dominant soil types within the CI are pheozems and vertisols, with approximately $85 \%$ coverage. Pelic vertisol is common in the south, while haplic to luvic pheozems cover a majority of the central and northern portions of the watershed (Mahlknecht et al. 2004). Other soils of local significance within the basin are haplic xerosols and calcic cambosols. Accumulations of calcium carbonate (caliche) immediately beneath the solum are common in parts of the watershed.

The CI is an intermountain sedimentary basin with a low point of 1,850 (m.a.s.l.) and high points of around 2,850 m.a.s.l at the peaks of the Sierra Guanajuato in the west. 


\subsubsection{Geology and lithology}

The CI is located at the intersection of three geologic provinces: the Sierra Madre Occidental (SMOc): the Sierra Madre Oriental (SMOr); and the Transmexican Volcanic Belt (TMVB) (Ferrari et al. 2000). The eastern portion of the basin, flanked by the SMOr, consists of a sequence of limestone, sandstone and marl deposited in the late Cretaceous period. The western boundary of the $\mathrm{CI}(\mathrm{SMOc})$ consists of extrusive igneous deposits from the late Cretaceous and early Tertiary periods. During the late Tertiary period, the emplacement of three stratovolcanoes to the south (TMVB) caused the hydrogeologic closing of the basin (Navarro de León, Gárfias-Soliz, and Mahlknecht 2005). The exposed volcanic rock, found at higher elevations, is of andesitic, rhyolitic, and basaltic composition, while the grabens have been filled in with thick layers of vocanoclastic sediments. The foot of the mountains are composed of breccias and partially-consolidated conglomerates within a matrix of course sand and gravel, and the plains consist of gravel, sand, silt, clay and volcanic ash. The valley fill ranges from a few meters in depth near the exposed mountainous rock to $460 \mathrm{~m}$ in the center of the basin (Navarro de León, Gárfias-Soliz, and Mahlknecht 2005).

\subsection{Human Geography}

\subsubsection{Historical causes of land use and land cover change}

Within most of what is known today as the Bajío there was little or no permanent settlement prior to the arrival of Cortez (Butzer et al. 1997); several semi-nomadic tribes, which together form the larger group of people known as the Chichimecas, inhabited much of the northern and Central Mexican highlands. To the south, however, the Valley of México 
(northeast of present-day Districto Federal) was settled by several sedentary Mesoamerican ancient civilizations — the Teotihuacan, Toltec and Aztec empires. Although these more advanced native cultures established permanent agriculture through complex irrigation systems and terraces, the tribes that inhabited parts of the Bajío left relatively little impact on the landscape.

The environmental conditions associated with the pre-settlement era are difficult to establish, but have been transcribed from documentation linked to land grants (mercedes) awarded to Criollos from 1542-91. Vegetation descriptions in these mercedes are more physiognomic than floristic, resulting in some generic diversity being lumped into single species (e.g., mesquite). Nevertheless, the vegetation inferences made by Butzer et al. (1997), give a sense of the pre-colonial vegetative cover and environmental condition of the Bajío. Each cover type is separated by landform and is generally described by Butzer et al. (1997) as follows:

i. Riverine/lacustrine areas were composed of riparian woodlands of mesquite, bald cypress groves and willow breaks with localized reed stands. Marshy ponds and live oak woodlands in arroyos indicate that gullying was not active at this time. An ecotone of tall mesquite trees, wetlands with reed swamps, and grassy flats was present on the fringes of lakes.

ii. Level vertisolic plains were largely open with mesquite and acacia groves and an understory of thorny succulents. Seasonal marshes and lakes were common in this landform.

iii. Mildly sloping plains with coarser substrates were occupied by bushy and thorny xeric plant communities, such as those dominated by Nopal or other cacti from the genus Opuntia.

iv. Moderately sloping uplands again consisted of alternate open/mesquite and acacia associations, with scrub oak present in some areas.

v. Mountains were primarily composed of live and deciduous oak.

Land use changes within the Bajío can generally be broken into three periods of time: semi-mobile Chichimec and Tarascan agricultural settlement prior to Spanish intrusion in the 
early 1500s; Spanish-Criollo settlement from the early 1500s through the early 1800s; and modern agricultural and industrial development from the early 1800s to present day.

Pre-hispanic disturbances to vegetation in the form of clearings were localized to the southern and southeastern margins of the Bajío, as the more nomadic Chichimec tribes controlled the north and the more agriculturally-oriented Otomí and Tarascan people controlled the south. After about 1520, the Otomí and Tarascan people expanded from their traditional settlements in Jilotepec and the area around Lake Cuitzeo and Yuriria to Celaya, Querétaro, and outliers further afield such as San Miguel.

Throughout the first half of Spanish-Criollo settlement, the dominant land use was open range stockraising, a practice which had relatively little impact on vegetation due to longdistance transhumance (Butzer et al. 1997). The discovery of silver near the city of Guanajuato in the 1552 changed the economic trajectory of the region as it increased the value and interest that the Spanish placed on the Bajío. The initial surge in population brought about by the mining industry was followed by increased wealth and a correlated increase in demand for goods and services. The latter half of Spanish-Criollo colonizationstarting in the mid-1700s_-brought another population boom that led to intensified pressure on resources within the Bajío. Throughout the 1800 s, as areal silver mines began to wane in productivity, the region's economy became increasingly focused on the agricultural production of grains (especially wheat, corn, barley and beans). At the end of the nineteenth century a railroad linking the Bajío to México City ensured marketability for its crops. Such agricultural growth relied heavily on the construction of multiple irrigation channels, canals, and dams to "plumb" an otherwise semi-arid landscape. By 1900, the run-of-the-river irrigation potential of the tributaries of the larger Lerma basin had been almost entirely 
developed. From 1930-2000 the area under irrigation within the Lerma Basin increased a minimum fivefold, and possibly as much as 7.5; by the end of the 1980s basin storage capacity reached $4499 \mathrm{Mm}^{3}$ — nearly equivalent to the basin's annual volume of surface water runoff (Wester et al. 2009).

Between 1960 and 1982, a period of agricultural modernization took place within the Bajío. The commercial production of sorghum, used primarily for livestock silage, displaced traditional crops such as wheat, maize and beans. During this time, the amount of irrigated land dedicated to sorghum production increased more than 100 fold, from 1,278 ha to 150, 681 ha (Marañón 2006). Concurrently, the number of chickens raised in México during this time rose precipitously from 77 million to over 240 million. The Bajío increasingly became the main supplier of meat and dairy products to México's urban centers, and domestic policy encouraged not just inward agricultural modernization, but external modernization as well. In addition to advances in infrastructure and changes in crop production, the agroindustrial development seen throughout the Bajío today is a result of multinational economic integration. Trade liberalization (e.g., North American Free Trade Agreement) in recent decades has increased the flow of foreign direct investment in commercial food processing within the Bajío.

As communally-owned property, the ejidal land surrounding San Miguel de Allende has been less impacted by external market forces than the more fertile and privatized Bajío land to the south. With more of a focus on local subsistence, the ejidos from which the nine subcatchments of interest in the present study are found have been impacted by unregulated grazing, and wood-harvesting. The voluntary implementation of land use best practices such as grazing exclosures and rotation, terracing, and prevention of wood-harvesting have only 
recently been introduced to ejido leaders and residents. Moreover, the adoption of such practices is limited by the availability of funding to sponsor educational outreach.

Consequently, much ejido-owned land still suffers from high rates of erosion-gullying is evident in several of the ejidos included in this study. 


\section{Methods}

The first three sections_-field methods, and Geographic Information Systems (GIS) methods, and statistical methods_-provide a detailed description of the materials, data, and methods used in this study. The fourth section details methodological limitations.

\subsection{Field Methods}

The field data were collected as a theoretical link to the effectiveness of a check dam as defined by its ability to retain sediment flows. For this study, pebble counts taken on the upstream and downstream side of a check dam provide this theoretical connection. The channel surface grain size data obtained from field sampling schemes such as pebble counts reveal much about local fluvial sediment transportation dynamics. For example, larger grain sizes are generally associated with areas of higher erosivity, while smaller grain sizes indicate lower streamflow velocities and deposition (Bundt and Abt, 2001).

Other studies have estimated the volume of sediment trapped behind check dams as a measure of efficiency (e.g., Mekonnen et. al. 2015). The aim of these other studies is different however, in that their primary focus is the siltation of downstream reservoirs (e.g., volume of sediment withheld from basin outlet). Although avoiding siltation of the Presa Allende is an ecosystem service worthy of consideration, more important to this study is the re-establishment of natural fluvial equilibrium through the recruitment of riparian species.

Two evidence-based conclusions from the literature are relevant here: i) effective rooting of riparian species along ephemeral streams in desert environments is limited by water availability (Lazaro et al. 2001); and ii) finer particle sizes have been shown to support 
denser patches of vegetation through higher soil water retention in semi-arid fluvial environments (Hamdan and Stromberg 2016). In this study, the use of particle size as an indicator of potential recruitment of riparian species rests on the above observations. The difference in distributions of surface grain sizes taken on either side of a check dam is therefore assumed to be a proxy for the ability of a check dam to retain mobilized sediment and create edaphic conditions that favor healthy riparian habitats. More specifically, the greater the difference $\left(\mathrm{DsD}_{50}-\mathrm{UsD}_{50}\right)$ in the median of opposing downstream $\left(\mathrm{DsD}_{50}\right)$ and upstream $\left(\mathrm{UsD}_{50}\right)$ distributions, the greater the indication of check dam effectiveness. The potential influence of basin characteristics such as discharge and size are controlled by comparing the difference in medians across different check dams, as opposed to comparing the raw $\mathrm{D}_{50}$ values.

\subsubsection{Site Selection and Equipment}

Before travelling to the study area, the locations of 30 check dam sites were selected from an existing SRL geodatabase. In the context of this study, a site is representative of one series of check dams within a single stream reach (there may be several sites within an ejido). Although initial site selection was based on proximity to San Miguel de Allende, local knowledge of accessibility dictated the final subset of sites visited. A total of 17 sites where check dams had been constructed since 1995 were visited in the field during August, 2014. At four of these sites there was either no discernible sign of check dams or the structural conditions of those found were such that measurement was not possible. Within the remaining 13 sites at which check dams were found to have unaltered or slightly/heavily compromised functionality (see section 3.1.2 for class descriptions), a total of 21 individual 
check dams were chosen for measurement. Table 3 provides a description of each check dam visited in the field.

The original 30 sites were downloaded from the SRL project geodatabase to a handheld GPS device (Trimble Juno 3B). A data dictionary was created and downloaded onto the handheld GPS device to accommodate digital data collection of grain sizes, bankfull channel widths, and land use/ecologic conditions. A metal sieve template (Gravelometer) was used to measure grain sizes, and a field tape was used to measure bankfull channel widths. 
Table 3. Description of check dams visited in the field. Name = ejido designation; numeral = particular subwatershed, where there is more than one subwatershed within an ejido; capital letter = upstream/downstream position of a particular check dam within a subwatershed, where " $U$ " is furthest upstream, "I" is intermediate, and " $D$ " is furthest downstream. An asterick $\left({ }^{*}\right)$ indicates a check dam that was located, but not in measurable condition. Ecologic disturbance types: $M W$ = Mass Wasting; $G=$ Grazing; $A=$ Agriculture.

\begin{tabular}{|c|c|c|c|c|c|}
\hline Check Dam ID & $\begin{array}{l}\text { SRL } \\
\text { Project? }\end{array}$ & $\begin{array}{l}\text { Same as } \\
\text { Original SRL } \\
\text { Location? }\end{array}$ & $\begin{array}{l}\text { Year } \\
\text { Constructed }\end{array}$ & Type & $\begin{array}{l}\text { Ecological } \\
\text { Disturbance }\end{array}$ \\
\hline Alcocer & Yes & Yes & 2011 & Rock & G \\
\hline Alonzo Yáñez U & Yes & Yes & 2002 & Rock & G \\
\hline Alonzo Yáñez D & Yes & Yes & 2002 & Rock & G \\
\hline Augustín González $1 \cup$ & Yes & No & 2004 & Rock & None \\
\hline Augustín González 1D & Yes & No & 2004 & Rock & None \\
\hline Augustín González 2U & Yes & No & 2004 & Rock & MW \\
\hline Augustín González 2D & Yes & No & 2004 & Rock & $G, A$ \\
\hline Augustín González 3 & Yes & No & 2004 & Rock & G, MW \\
\hline Cabras de Begoña U & Yes & Yes & 2002 & Rock & G \\
\hline Cabras de Begoña I & Yes & Yes & 2002 & Rock & G \\
\hline Cabras de Begoña D & Yes & Yes & 2002 & Rock & G \\
\hline Estancia de Canal U & No & $\mathrm{n} / \mathrm{a}$ & 1995 & Rock & None \\
\hline Estancia de Canal D & No & $\mathrm{n} / \mathrm{a}$ & 1995 & Rock & None \\
\hline La Cruz del Palmar 1 & Yes & No & 2012 & Gabion & None \\
\hline La Cruz del Palmar 2 & Yes & No & 2012 & Gabion & MW \\
\hline Fajardo de Támbula U & Yes & Yes & 2002 & Rock & None \\
\hline Fajardo de Támbula D & Yes & Yes & 2002 & Rock & None \\
\hline El Salitre U & Yes & No & Not Known & Wood & MW \\
\hline El Salitre D & Yes & No & Not Known & Wood & MW \\
\hline Sosnabar 1 & Yes & Yes & 2002 & Rock & G \\
\hline Sosnabar 2 & Yes & Yes & 2002 & Rock & G \\
\hline Augustín González 4* & Yes & No & 2012 & Rock & G \\
\hline Estancia de Canal 2 & Yes & Not Located & $\mathrm{n} / \mathrm{a}$ & $\mathrm{n} / \mathrm{a}$ & $\mathrm{n} / \mathrm{a}$ \\
\hline La Tinaja & Yes & Not Located & $\mathrm{n} / \mathrm{a}$ & $\mathrm{n} / \mathrm{a}$ & MW \\
\hline El Salitrillo & Yes & Not Located & $\mathrm{n} / \mathrm{a}$ & $\mathrm{n} / \mathrm{a}$ & $\mathrm{n} / \mathrm{a}$ \\
\hline
\end{tabular}




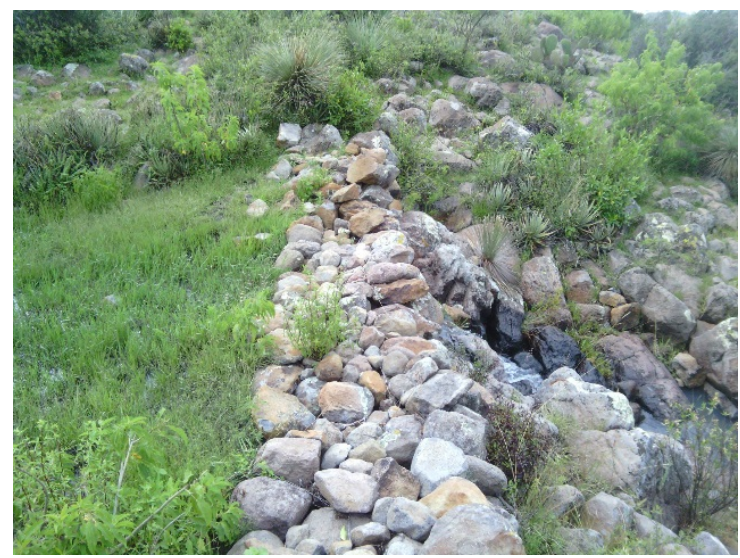

(a)

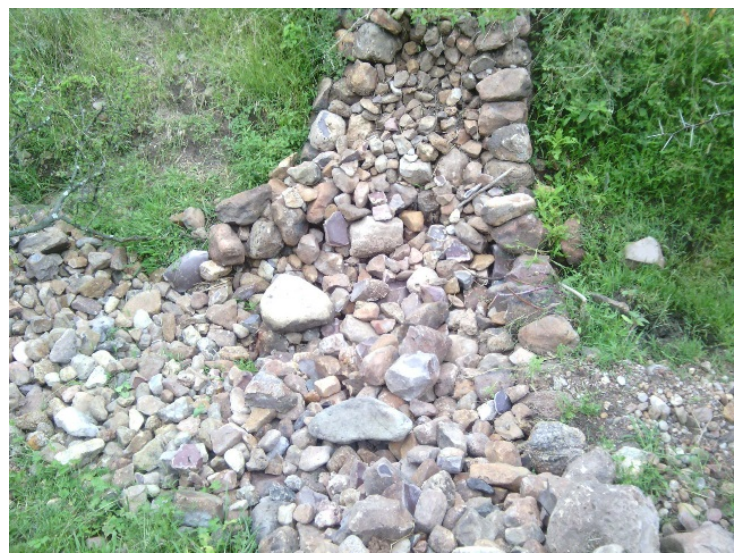

(c)

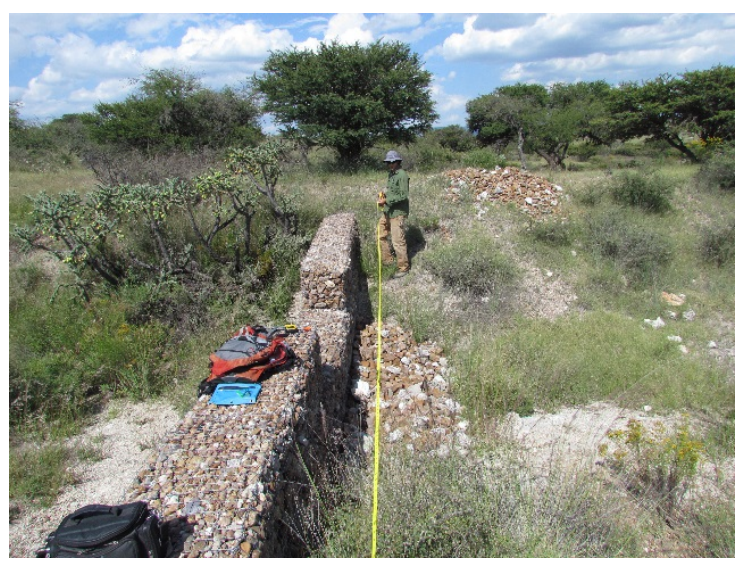

(b)

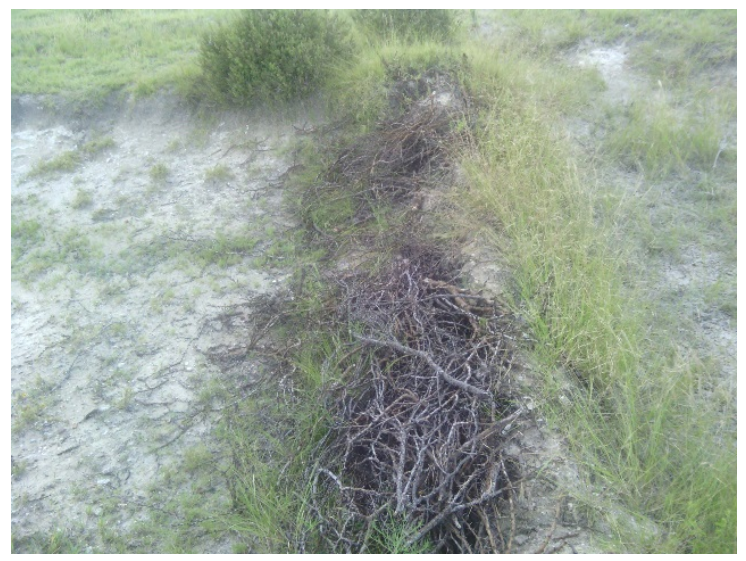

(d)

Figure 7. Photos showing the types and conditions of check dams visited in the field. (a) a rock check dam classified as "unaltered functionality"; (b) an example of a gabion; (c) a rock check dam that was not measured due to a lack of functionality; (d) and an example of a woody debris check dam. 


\subsubsection{Site-Scale Data Collection}

Most of the check dams visited were SRL projects, however some were not located in the same position as the original database points suggested. This would seem to indicate that the original check dams had disappeared due to high flow events and that other check dams had been built since. Although the majority of check dams seen and measured in the field were simple rock structures, two gabiones (La Cruz del Palmar 1 and 2) and two woody debris (El Salitre A and B) check dams were also measured. Figure 7 provides a visual context for each type of check dam. The type of ecologic disturbance most often noted in the field was grazing, followed by mass wasting in the form of headcutting and badland development. Maize crops were mostly found in lower elevations, while steep slopes precluded agriculture from many of the upland sites where check dams were located.

At each check dam visited, pebble counts were conducted directly upstream and downstream using a method originally described in Wolman (1954). This technique has been widely used in geomorphic and non-geomorphic studies as a means of quantifying bed surface roughness through characterization of grain size distributions (Kondolf 1997). An important consideration when conducting pebble counts is sample selection methodology. So as not to bias each sample distribution, use of a grid system is common practice. However, if use of a formal grid frame is impractical due to remoteness of site, an alternative technique is to "draw each pebble from beneath the tip of the toe of his boot", each proceeding step taken from the toe of the preceding step (Wolman 1954). Each grain sample is then measured with a Gravelometer and recorded into size classes. The smallest size opening that a grain sample is able to pass through becomes that sample's recorded class. 
Frequency distributions of different sample sets can then be created that offer valuable geomorphic insight into the fluvial location of interest.

A total of 96 individual grain samples were measured and recorded at each check dam. Six transects of 16 heel-to-toe steps were walked at each check dam-three on the upstream side and three on the downstream side. Each transect began at the base of a given check dam from approximately $25 \%, 50 \%$, or $75 \%$ of bankfull channel width (Figure 8). Photos were also taken at the beginning of each transect.

In addition to pebble counts taken at each check dam, bankfull channel width and check dam type, age, condition, as well as surrounding land use/ecologic disturbances were observed and noted at each site. When evident, changes in vegetation community type were used to establish bankfull conditions. In the case of channels that lacked visual evidence of transitioning riparian/upland vegetation community types, check dam cross-sectional length was measured. Check dam conditions were ranked according to visual inspection and judgement in the field. Check dams with uncompromised structure (original form intact) were classified as "unaltered functionality"; check dams with approximately $25 \%$ compromised structure were classified as "slightly compromised functionality"; and check dams with approximately 50\% compromised structure were classified as "heavily compromised functionality". Check dams found with greater than $50 \%$ compromised structure were not measured. Channel bank scouring, although only observed at two sites, was also a factor in considering check dam condition. 


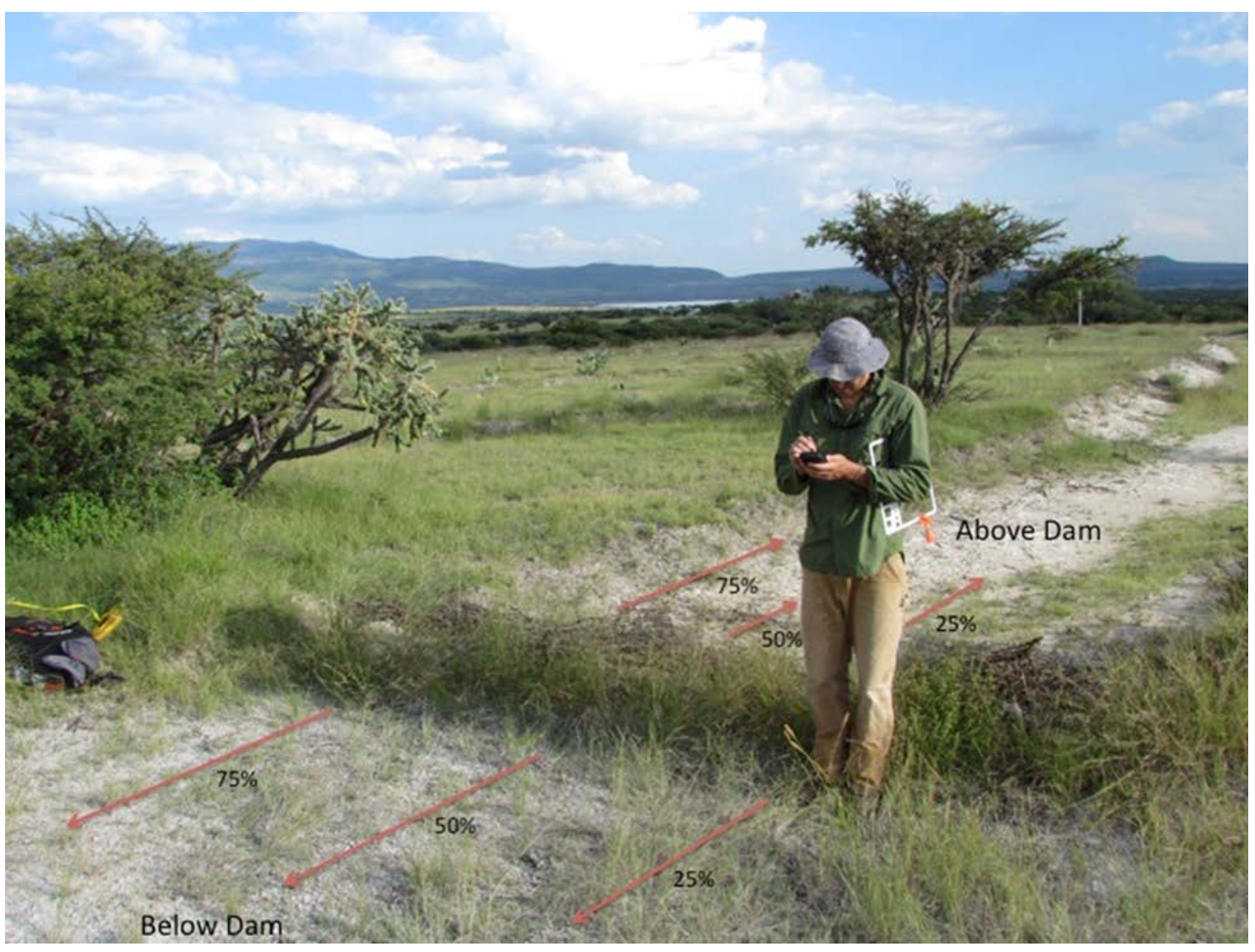

Figure 8. Illustration of the protocol used in the field.

\subsection{GIS Methods}

ArcGIS 10.2 was used to derive subwatershed attributes that were expected to correlate well with the $\mathrm{DsD}_{50}-\mathrm{UsD}_{50}$ values between check dams (see Table 4). A detailed description of the datasets and processes used to derive each variable is explained in the following sections. Of the watershed variables estimated/modeled, total stream power is of greatest interest due to its established link with fluvial geomorphologic change (Talling and Sowter 1998). This link is further detailed in section 3.2.2. 


\subsubsection{Non-stream power subwatershed variables}

Several subwatershed variables not directly related to stream power were of interest due to their potential link to $\mathrm{DsD}_{50}-\mathrm{UsD}_{50}$ values. All of these variables—elevation, subwatershed area, distance from channel head, subwatershed shape, Strahler stream order, canopy cover, brush cover, cropland, and barren land-were derived from GIS and/or aerial imagery.

The elevation associated with each check dam was extracted from a five-meter, LiDAR-derived digital elevation model (DEM) obtained from Instituto Nacional de Estadistíca y Geographía (INEGI). After delineating each subwatershed of interest (see section 3.2.2 for more detail), several subwatershed dimensions were measured in ArcGIS 10.2. The circumference of each subwatershed polygon was measured to calculate subwatershed area; the length and width along each subwatershed's long and short axes were measured to calculate subwatershed shape; and the length of each subwatershed's main stream course (from channel head to furthest downstream check dam) was measured to calculate distance from channel head. Mean watershed slope and Strahler stream order were calculated using existing tools within the Spatial Analyst toolbox.

Percentage of canopy/brush cover and cropland/barren land for each subwatershed were calculated through the following steps: i) high-resolution imagery for each subwatershed was imported into ArcGIS 10.2 from Google Earth Pro; ii) all images were georeferenced from a geographical coordinate system (GCS) to a projected coordinate system (PCS)—specifically, Universal Transverse Mercator (UTM) zone 14 North; and iii) four cover classes (canopy cover, brush cover, cropland, and barren land) were delineated 
using supervised classification. The cumulative classified area of canopy/brush cover and cropland/barren land for each subwatershed was then divided by the total subwatershed area of each site.

\subsubsection{Stream Power Model}

Stream power is a measure of the main driving forces acting in a channel and determines a stream's capacity to transport sediment and perform geomorphic work (Bizzi and Lerner 2015). It follows that stream power is related to the functionality of a check dam, as one purpose of a check dam is to inhibit a stream's ability to transport sediment that is entrained in flow. Thus, the relative stream power within a stream reach can potentially be used as a means of explaining the observed variability in check dam functionality.

Total stream power (TSP) is a function of three variables, one of which is constant (the specific weight of water), and two of which must be measured or estimated. The two estimated variables, local channel slope and local channel discharge, can both be calculated from a DEM (Parker et al. 2015). Total stream power is mathematically defined as

$\Omega=\gamma Q S_{e}$

where $\Omega$ is TSP $\left(\mathrm{W} \mathrm{m}^{-1}\right) ; \gamma$ is the specific weight of water $(9810 \mathrm{~N}) ; Q$ is discharge $\left(\mathrm{m}^{3} \mathrm{~s}^{-1}\right)$; and $S_{e}$ is channel slope energy $\left(\mathrm{m} \mathrm{m}^{-1}\right)$.

The following sections provide a description of the process used to calculate TSP within GIS. There are five main groups within the model: i) watershed delineation; ii) 
channel slope; iii) channel discharge; iv) channel stream power; and v) change in channel stream power (Figure 9).

\section{Watershed Delineation}

This study used established GIS methods to derive stream networks and watershed polygons from a DEM. Several tools from within the Spatial Analyst Toolbox in ArcGIS 10.2 were used in this process. First, the DEM was filled in order to eliminate any false sinks and ensure that the digital model accurately reflects natural drainage patterns. Once filled, each cell within the DEM was assigned a direction of flow and subsequently a number which represents the amount of contributing cells for all target cells. The resulting flow accumulation raster was then reclassified to create a vector stream network. A threshold of 1000 accumulated cells was used to establish the origin of channel heads. The final step of watershed delineation requires the creation of pour points. For this study, the furthest downstream check dam within a site was used as each subwatershed's pour point. From these user-defined points along the stream channel, each subwatershed was delineated and vector polygons were created.

\section{Channel Slope}

The process of creating a channel slope image begins with the filled DEM. After extracting the channel elevation profile, slope was calculated via an existing tool within ArcGIS 10.2. For each target cell, this output returns the maximum percent change from within a $3 \times 3$ cell window. The cell values associated with the extracted channel are the only float point numbers remaining for the neighborhood operation (cells with a NoData value are excluded from the calculation). Given that the desired slope units are $\mathrm{m} \mathrm{m}^{-1}$ (rise over 
run), a conversion was necessary. The final channel slope output represents an approximation of local channel slope energy and was substituted into Equation 1 as the term $S_{e}$

\section{Channel Discharge}

Conceptually, there are two primary components needed to model a network of spatially continuous stream discharge values within a GIS. The first is an image that represents the drainage area values corresponding to each contiguous cell within a stream network. The second is an equation that is representative of the relationship between the drainage areas and corresponding observed discharge values for similarly-sized watersheds within the region of interest. 


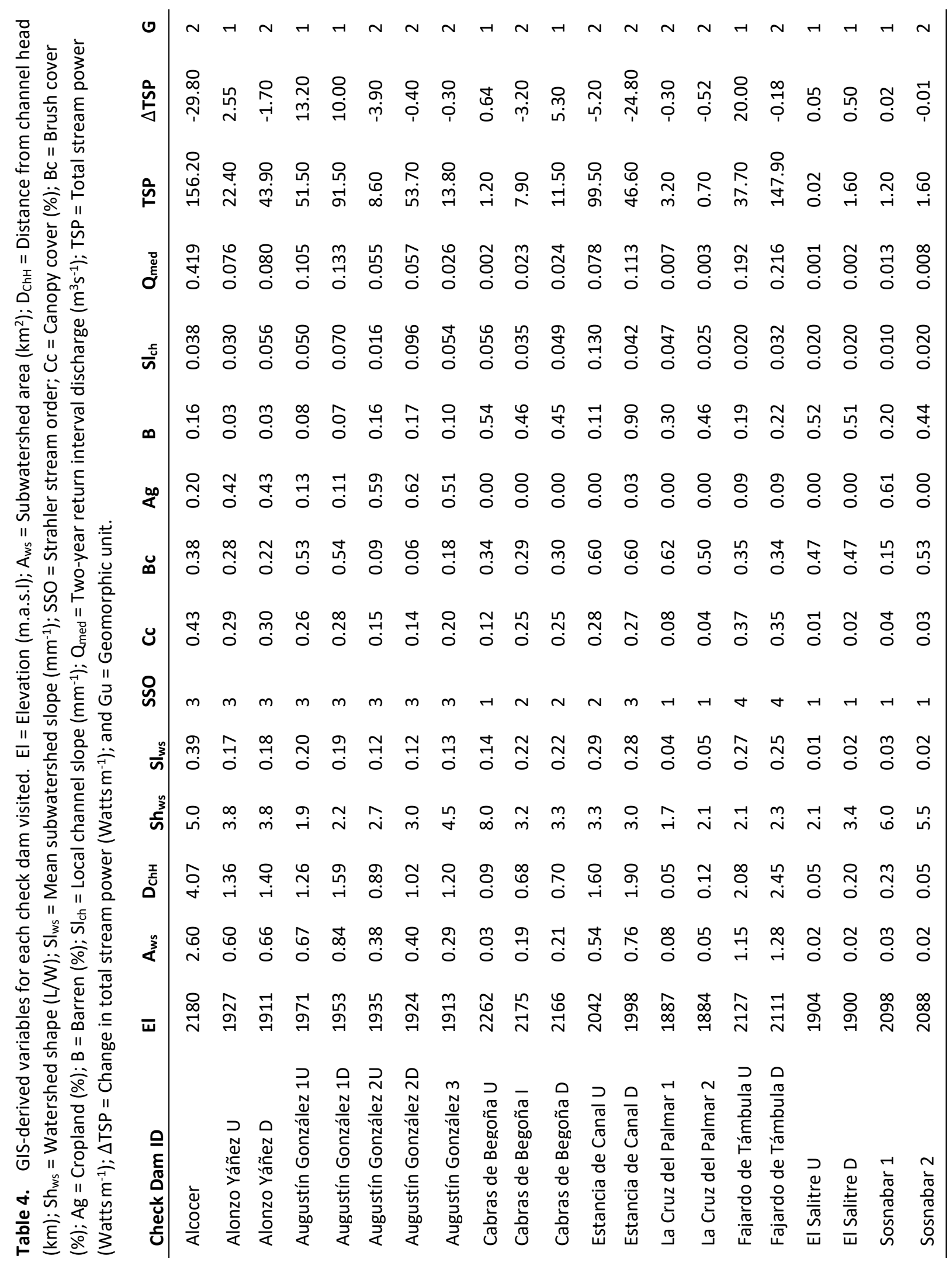




\section{Drainage Area Image}

The calculation of flow accumulation is a necessary step in the GIS workflow used for watershed and stream network delineation. As implied by its name, flow accumulation simply represents the total number of cells that flow into any given cell within a DEM. By extracting only the flow accumulation totals along the stream channel and applying a conversion to account for cell size, an image can be produced that approximates the drainage area associated with each continuous channel cell.

\section{Regional Discharge Area Relationship}

The majority of stream networks worldwide, particularly within headwater reaches, are ungauged or poorly gauged. Inconsistency in hydrometric data collection is largely attributable to lack of funding or institutional capacity and an inability to see the long-term value of such data (Razavi and Coulibaly 2013). The resulting unevenness of surface hydrologic data from watershed to watershed the world over has prompted the necessity of what has been termed "regionalization", which refers to the transfer of hydrologic information from gauged to ungauged locations (Samuel, Coulibaly, and Metcalfe 2011). However, identifying and providing the appropriate regionalization methods remains a challenging task for researchers. In response to this challenge, the International Association of Hydrological Sciences (IAHS) launched a decade-long initiative (2003-2012), the Prediction in Ungauged Basins (PUB), intended to support the scientific community's efforts to achieve major advances in the capacity to make predictions in ungauged basins (Sivapalan et al. 2003). 
Razavi and Coulibaly (2013) provide a detailed review of the regionalization methods used to calculate stream discharge in ungauged basins. Of the two classes of regionalization methods—-hydrologic model-independent and hydrologic model-dependent—-modelindependent methods are less complex and have lower data requirements, and thus are a better match for the present study. 


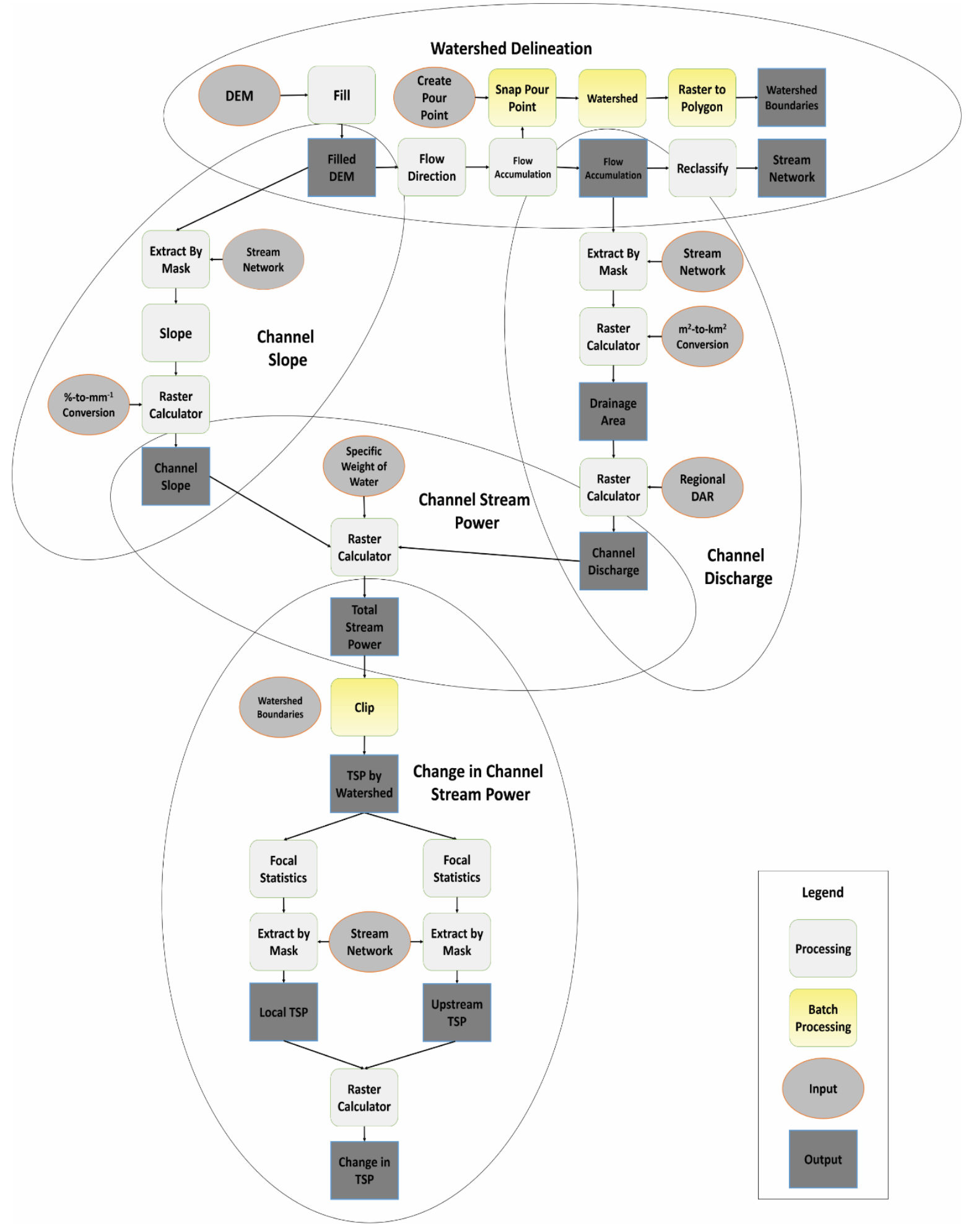

Figure 9. Chart of GIS workflow for calculating spatially explicit total stream power. 
Within this category of regionalization methods, regression-based approaches are most commonly used for characterizing relationships between hydrologic responses and catchment attributes (Razavi and Coulibaly 2013). A linear regression-based approach is used in this study and is detailed below.

The first step in establishing an appropriate method for estimating discharge at ungauged locations is the selection of watershed attributes. For the purposes of calculating total stream power, the median flood $\left(\mathrm{Q}_{\mathrm{med}}\right)$ is commonly used as the dependent variable (Jain et al. 2006; Barker et al. 2009). As described by Razavi and Coulibaly (2013), many watershed attributes, both physiographic and climate based, can be used as the independent variables in the regression equation. This study uses the single attribute of catchment area because it is relatively easy calculate yet provides a good prediction of streamflow. Other studies have compared performance differences between hydrologic response variables and various watershed attributes. For example, Bizzi and Lerner (2015), related discharge to Shreve's Index (Shreve, 1966), which is a stream order classification system that accounts for the non-linearity between flow and distance downstream due to tributaries, and drainage area and found a minor difference in their respective $\mathrm{R}^{2}$ values.

After selecting the appropriate attribute(s) for the analysis, data collection and processing must be performed. To the greatest degree possible, gauged data used in the analysis should be taken from stations that match the ungauged locations with respect to watershed size. Proximity to the watershed of interest is also an important parameter. A third important consideration is the extent to which the flow of the donor watersheds is controlled. Due to the small size of the subwatersheds of interest in this study, the smallest of all nearby gauged watersheds was utilized. Furthermore, and regardless of period-of- 
record length, by avoiding downstream (and theoretically more controlled) gauge sites, a more natural peak flow regime is represented in the regression equation. The locations, catchment areas and periods-of-record of the chosen donor sites are shown in Table 5.

Table 5. Description of gauged watersheds used to calculate the drainage area relationship.

\begin{tabular}{lrrlccr}
\hline Stream Gauge & $\begin{array}{c}\mathbf{Q}_{\text {med }} \\
\left(\mathbf{m}^{3} \mathbf{s}^{-1}\right)\end{array}$ & $\begin{array}{c}\text { Area } \\
\left(\mathbf{k m}^{2}\right)\end{array}$ & Latitude & Longitude & $\begin{array}{c}\text { Euclidian Distance } \\
\text { from Study Area } \\
(\mathbf{k m})\end{array}$ & $\begin{array}{c}\text { Period } \\
\text { of } \\
\text { Record } \\
\text { (yrs) }\end{array}$ \\
\hline El Tigre & 6.0 & 25 & $21^{\circ} 04^{\prime \prime} 17^{\prime}$ & $101^{\circ} 27^{\prime \prime} 48^{\prime}$ & 68.5 & 4 \\
González & 50.6 & 120 & $20^{\circ} 53^{\prime \prime} 15^{\prime}$ & $100^{\circ} 50^{\prime \prime} 45^{\prime}$ & 0.0 & 6 \\
El Chapin & 91.9 & 226 & $20^{\circ} 52^{\prime \prime} 17^{\prime}$ & $101^{\circ} 14^{\prime \prime} 08^{\prime}$ & 40.7 & 38 \\
San Juan Temascatio & 147.7 & 251 & $20^{\circ} 44^{\prime \prime} 00^{\prime}$ & $101^{\circ} 13^{\prime \prime} 27^{\prime}$ & 42.8 & 22 \\
Cinco Senores & 162.6 & 408 & $20^{\circ} 57^{\prime \prime} 30^{\prime}$ & $100^{\circ} 55^{\prime \prime} 00^{\prime}$ & 10.7 & 38 \\
\hline
\end{tabular}

Annual peak discharge for donor gauge sites was collected from the Banco Nacional de Datos de Aguas Superficiales (BANDAS) database, managed by Comision Nacional del Agua (CONAGUA), while the associated drainage area for each site was gathered from a web application operated by BANDAS (CNA 2015). The statistical analysis used to convert the data series of peak annual discharge values $\left(\mathrm{Q}_{\max }\right)$ for each site's period-of-record into estimated discharge values for 2, 5, 10, 25, 50, 100, and 500-year recurrence intervals is outlined in the subsequent section.

\section{Flood Frequency Distributions}

The peak flows associated with two-year recurrence intervals were extracted from frequency distributions constructed by employing the Log-Pearson Type III Distribution technique (IACWD, 1982). This technique is the standard statistical method used by U.S. federal agencies to predict and fit return intervals of various lengths to particular event 
magnitudes. There are six steps involved in calculating flood frequency distributions via the

Log-Pearson Type III technique:

i. $\quad Q_{\max }$ values for the period-of-record associated with each donor site are ranked from largest to smallest.

ii. The $\log$ of all $\mathrm{Q}_{\max }$ values is calculated.

iii. The variance, standard deviation, and skew coefficient for each log distribution is calculated. Variance can be defined as

$$
\sigma_{i}^{2}=\frac{\sum_{t=1}^{n_{i}}\left(z_{i t}-\bar{z}_{i}\right)^{2}}{n_{i}-1}
$$

where $\sigma_{i}^{2}=$ the sample variance at station $i ; n_{i}=$ the number of observed annual peak flows at station $i ; z_{i t}=$ the logarithm of annual peak flow at station $i$ in year $t$; and $\bar{z}_{i}=$ the mean of logarithms at station $i$. Standard deviation can be defined as

$\sigma_{i}=\sqrt{\frac{\sum_{t=1}^{n_{i}}\left(z_{i t}-\bar{z}_{i}\right)^{2}}{n_{i}-1}}$

where $\sigma_{i}=$ the sample standard deviation at station $i ; n_{i}=$ the number of observed annual peak flows at station $i ; z_{i t}=$ the logarithm of annual peak flow at station $i$ in year $t$; and $\bar{z}_{i}=$ the mean of logarithms at station $i$. Skew coefficient can be defined as

$g_{i}=\frac{n_{i} \sum_{t=1}^{n_{i}}\left(z_{i t}-\bar{z}_{i}\right)^{3}}{\left(n_{i}-1\right)\left(n_{i}-2\right) s_{i}^{3}}$

where $g_{i}=$ the skew coefficient at station $i ; n_{i}=$ the number of observed annual peak flows at station $i ; z_{i t}=$ the logarithm of annual peak flow at station $i$ in year $t$; $\bar{z}_{i}=$ the mean of logarithms at station $i$; and $s_{i}=$ the sample standard deviation of logarithms at station $i$.

iv. An unbiased skew coefficient, which accounts for station bias related to short periods of record for each log distribution, is calculated. Unbiased skew coefficient can be defined as

$G_{i}=\frac{\sum g_{i}}{n_{i}} \times g_{i}$

where $G_{i}=$ the unbiased skew coefficient at station $i ; \frac{\sum g_{i}}{n_{i}}=$ the regional skew coefficient; and $g_{i}=$ the skew coefficient at station $i$.

v. The resulting unbiased skew coefficient is then used along with a frequency factor look-up table (Table A1) to calculate $\mathrm{K}$ values for each recurrence interval (linear extrapolation is used to calculate $\mathrm{K}$ values for which the unbiased skew coefficient falls between the reference skew coefficients found in the look-up table).

vi. The discharge associated with $\mathrm{Q}_{\mathrm{med}}$ and/or other recurrence intervals are calculated. Qmed can be defined as

$Q_{\text {med }_{i}}=\bar{z}_{i}+K_{\text {med }_{i}} \times \sigma_{i}$ 
where $Q_{\text {med }_{i}}=$ the discharge associated with a two-year recurrence interval at station $i ; \bar{z}_{i}=$ the mean of logarithms at station $i ; K_{\text {med }_{i}}=$ the $\mathrm{K}$ value associated with a two-year recurrence interval at station $i$; and $\sigma_{i}=$ the sample standard deviation at station $i$.

The $\mathrm{K}$ values, estimated discharge values, and flood frequency distributions for the five donor gauge sites are shown in Figures 10.

\begin{tabular}{|ccc|}
\hline $\begin{array}{c}\text { Return Period } \\
\text { (yrs) }\end{array}$ & $\begin{array}{c}\text { Skew Coefficient } \\
\text { K(-1.345) }\end{array}$ & $\begin{array}{c}\text { Discharge Q } \\
\text { (mos) }\end{array}$ \\
\hline 2 & 0.217 & 6.0 \\
\hline 5 & 0.835 & 9.4 \\
\hline 10 & 1.054 & 11.0 \\
\hline 25 & 1.221 & 12.4 \\
\hline 50 & 1.300 & 13.1 \\
\hline 100 & 1.354 & 13.7 \\
\hline 500 & 1.391 & 14.0 \\
\hline
\end{tabular}

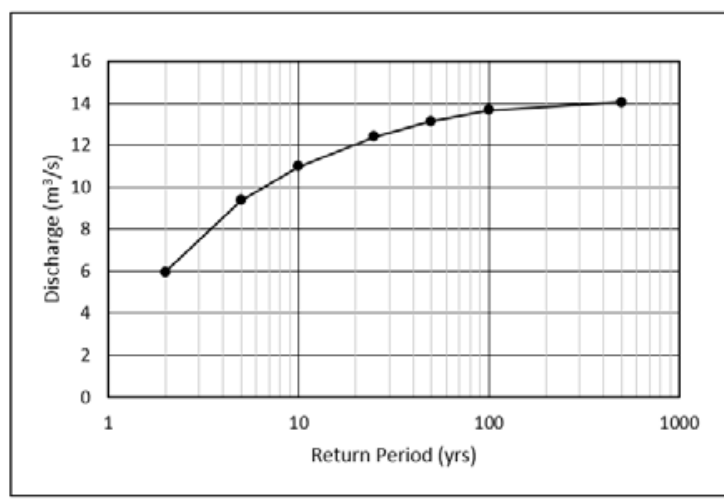

(a) El Tigre

\begin{tabular}{|ccc|}
\hline $\begin{array}{c}\text { Return Period } \\
\text { (yrs) }\end{array}$ & $\begin{array}{c}\text { Skew Coefficient } \\
\mathrm{K}(-8.459)\end{array}$ & $\begin{array}{c}\text { Discharge Q } \\
\left(\mathrm{m}^{3} / \mathrm{s}\right)\end{array}$ \\
\hline 2 & 0.139 & 50.6 \\
\hline 5 & 0.855 & 73.4 \\
\hline 10 & 1.157 & 86.4 \\
\hline 25 & 1.429 & 100.0 \\
\hline 50 & 1.580 & 108.4 \\
\hline 100 & 1.699 & 115.6 \\
\hline 500 & 1.797 & 121.8 \\
\hline
\end{tabular}

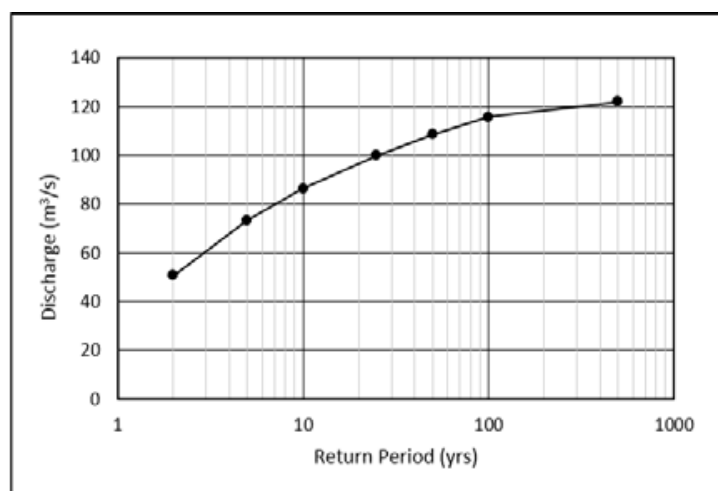

(b) González 


\begin{tabular}{|ccc|}
\hline $\begin{array}{c}\text { Return Period } \\
(\mathrm{yrs})\end{array}$ & $\begin{array}{c}\text { Skew Coefficient } \\
\mathrm{K}(-.7174)\end{array}$ & $\begin{array}{c}\text { Discharge Q } \\
\text { (mcs) }\end{array}$ \\
\hline 2 & 0.119 & 91.9 \\
\hline 5 & 0.857 & 185.6 \\
\hline 10 & 1.180 & 252.6 \\
\hline 25 & 1.481 & 336.6 \\
\hline 50 & 1.653 & 396.5 \\
\hline 100 & 1.793 & 453.2 \\
\hline 500 & 1.911 & 506.8 \\
\hline
\end{tabular}

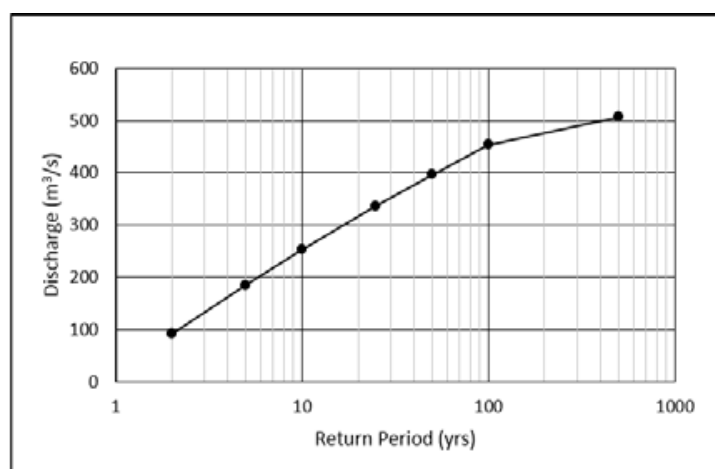

\section{(c) El Chapin}

\begin{tabular}{|ccc|}
\hline $\begin{array}{c}\text { Return Period } \\
\text { (yrs) }\end{array}$ & $\begin{array}{c}\text { Skew Coefficient } \\
\text { K(-1.8801) }\end{array}$ & $\begin{array}{c}\text { Discharge Q } \\
\text { (mcs) }\end{array}$ \\
\hline 2 & 0.292 & 147.7 \\
\hline 5 & 0.790 & 196.7 \\
\hline 10 & 0.925 & 212.6 \\
\hline 25 & 1.004 & 222.4 \\
\hline 50 & 1.032 & 226.1 \\
\hline 100 & 1.047 & 228.0 \\
\hline 500 & 1.055 & 229.0 \\
\hline
\end{tabular}

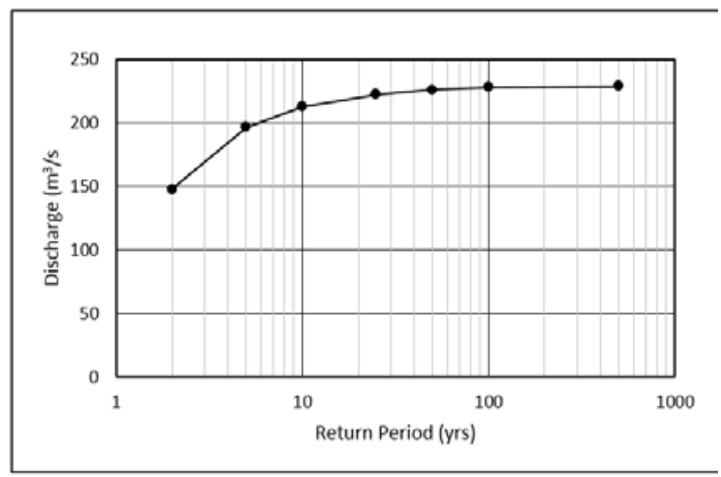

(d) San Juan Temascatio

\begin{tabular}{|ccc|}
\hline $\begin{array}{c}\text { Return Period } \\
(y / s)\end{array}$ & $\begin{array}{c}\text { Skew Coefficient } \\
\text { K(-1.0336) }\end{array}$ & $\begin{array}{c}\text { Discharge Q } \\
\text { (mcs) }\end{array}$ \\
\hline 2 & 0.165 & 162.6 \\
\hline 5 & 0.852 & 265.0 \\
\hline 10 & 1.127 & 322.3 \\
\hline 25 & 1.365 & 381.5 \\
\hline 50 & 1.490 & 417.1 \\
\hline 100 & 1.586 & 446.4 \\
\hline 500 & 1.661 & 471.1 \\
\hline
\end{tabular}

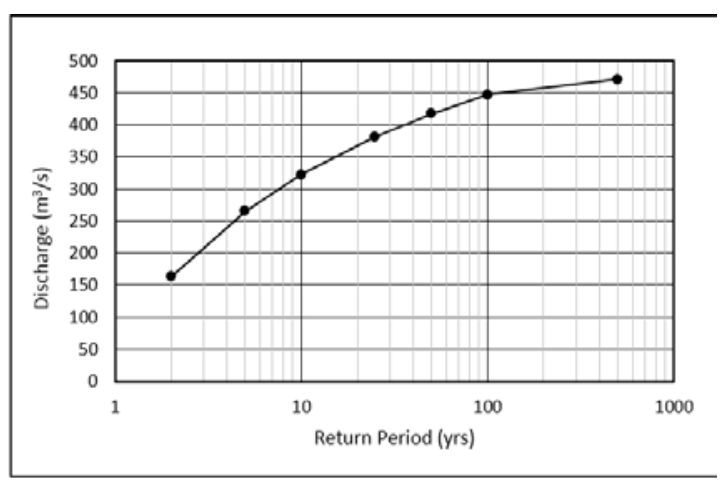

\section{(e) Cinco Senores}

Figure 10. K values and flood frequency distributions for donor gauge sites. 


\section{Discharge to Area Regression}

The $\mathrm{Q}_{\mathrm{med}}$ and associated drainage area values for each donor gauge station is plotted in Figure 11. Both variables were log-transformed and a linear regression analysis was performed. The regression line generated by the data shows a strong, positive linear correlation between the two variables. Over $98 \%$ of the variance observed in the plotted data points is explained by the linear function $y=1.2299 x-2.073$, where $y=\mathrm{Q}_{\text {med }}$; and $x=$ drainage area. This regression equation was applied to the drainage area image and the resulting cell values were converted from natural logarithmic units back into $\mathrm{m}^{3} \mathrm{~s}^{-1}$ units to create the final discharge output.

\section{Channel Stream Power}

The calculation of TSP at $\mathrm{Q}_{\mathrm{med}}$ along a stream channel is simply a matter of applying Equation 1 within a GIS. The product of the channel slope raster, the channel discharge raster and the specific weight of water yields continuous TSP values along the stream network of interest. This procedure was performed with the Raster Calculator tool in ArcGIS 10.2. 


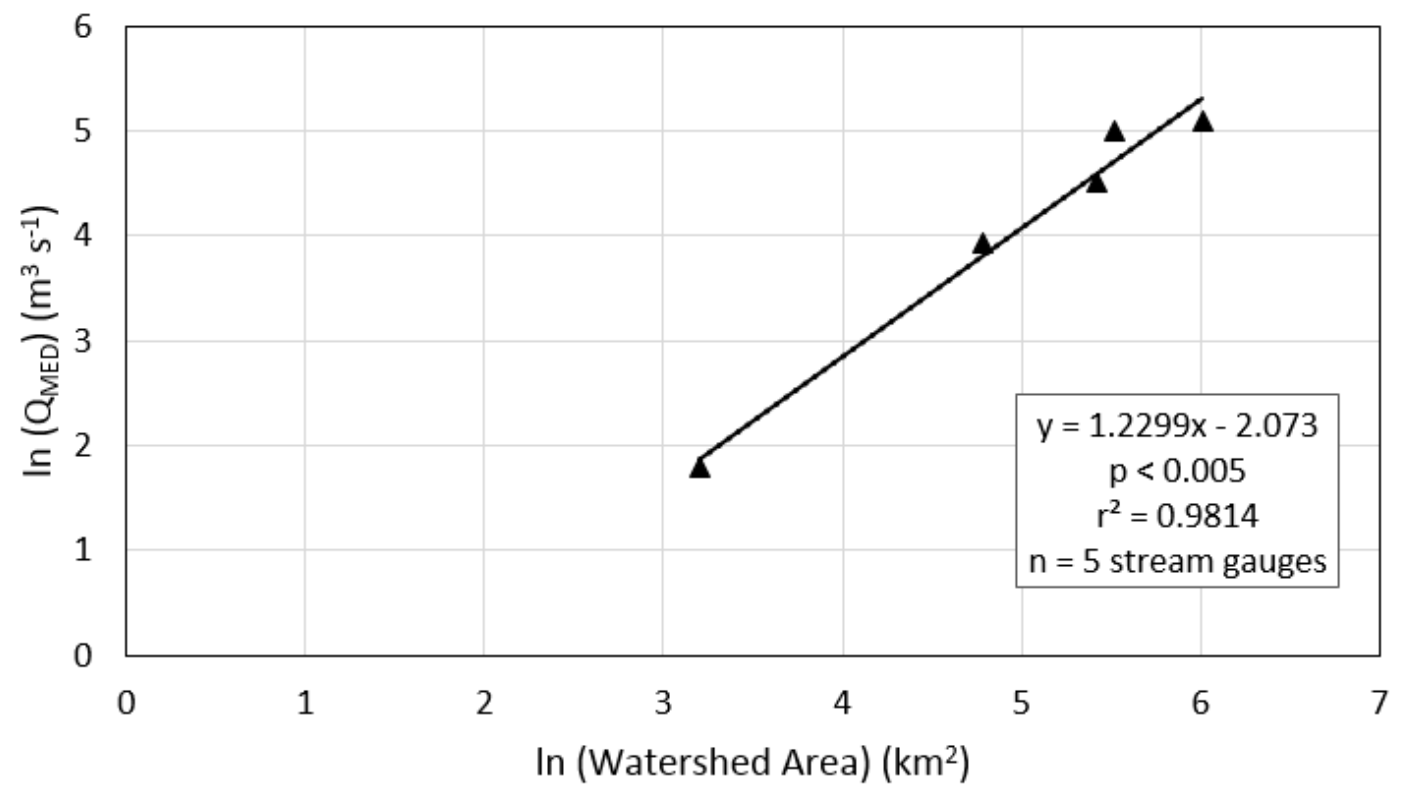

Figure 11. Relationship between $Q_{\text {med }}$ and drainage area for donor watersheds.

\section{Change in Stream Power}

In this study, the usage of change in total stream power $(\Delta \mathrm{TSP})$ provides the necessary data to classify a given stream reach as erosion or deposition-dominated. Previous studies have established the connection between stream power and channel sensitivity to erosion-deposition processes (Talling and Sowter 1998; Bizzi and Lerner 2015; Parker et al. 2015; Lea and Legleiter 2016). The working hypothesis of the present research is that check dams located in deposition-dominated sections of a stream channel will be more effective at retaining sediment than those sections of stream located in erosion-dominated areas, as indicated by higher values of $\mathrm{Ds}_{50}-\mathrm{UsD}_{50}$.

As the final nested workflow within the GIS model, the calculation of DTSP required several steps (Figure 9). First, the continuous TSP values associated with each headwater stream network of interest was clipped to the corresponding subwatershed boundary. Each 
individual stream network of TSP values was then processed to identify local TSP (TSP local and upstream TSP (TSP ${ }_{u p}$ ) contributions (Figure 12). Although both processes use the same tools within ArcGIS 10.2, the neighborhoods or specified grouping of cells to which the chosen statistical calculation is applied, are different. The size of neighborhood for both processes is based on the amount of smoothing desired and must also be consistent with the scale of analysis (i.e., size of watershed and spatial resolution of DEM). Care must be taken to ensure that neighborhood sizes match each study domain's scale. As Bizzi and Lerner (2015) demonstrate, larger neighborhood sizes result in the diminished influence of maximum and minimum local TSP values (i.e., the highest and lowest values are smoothed out).
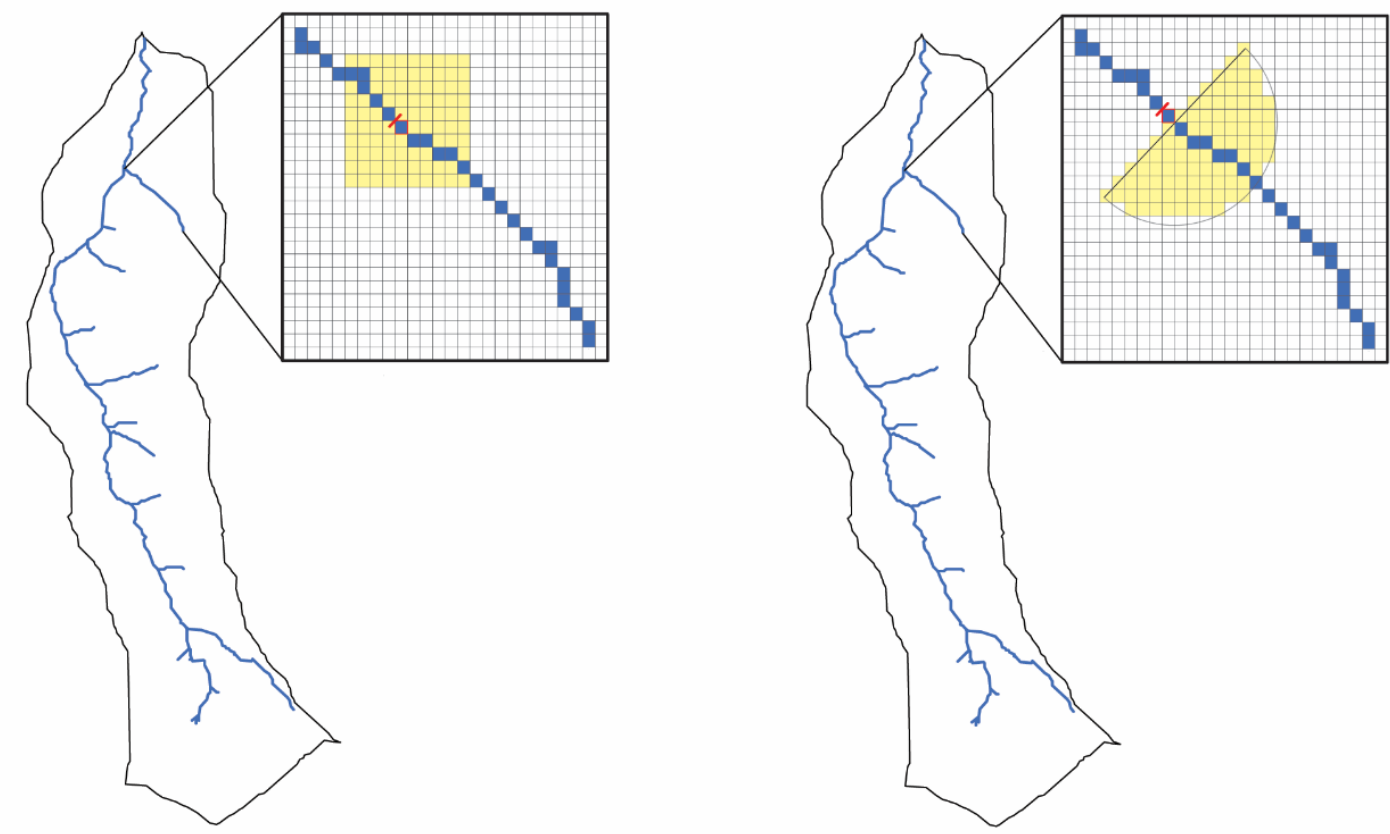

Figure 12. GIS method for calculating $T S P_{\text {local }}$ and $T S P_{\text {up }}$ (from left to right). $T S P_{\text {up }}$ neighborhood is not to scale. 
Due to the relatively small average watershed size in this study, a $10 \times 10$ rectangular neighborhood was used to calculate TSP local, and as with other neighborhood calculations run in this model, the output was limited to just the stream channel cells. For the calculation of TSP $_{u p}$, it was important that only the cells upstream from the target cell were included. A neighborhood size of 60 cells was used in order to capture a sufficient range of upstream variation in TSP. A half circular neighborhood shape was used. In this case, the target cell was located at the center of the half-circle and the direction of calculation was from channel head to the furthest downstream check dam at each site. The original stream network was then used to extract only the values of the stream channel at each site, and finally the two outputs were combined to create the $\Delta$ TSP image. The difference between average local and upstream TSP $\left(\Delta T S P=T S P_{\text {local }}-T S P_{u p}\right)$ indicates the potential of a reach to transport sediment entering from upstream: if positive, erosion should dominate; conversely, deposition should dominate if $\Delta$ TSP is negative (Figure 12) (Bizzi and Lerner 2015).

\section{Change in Stream Power Profiles}

The figures in Appendix B represent a final graphical output of each site's continuous $\Delta$ TSP. The profiles were produced by exporting each site's $\Delta$ TSP values from a GIS to tabular (csv) format. It was important to maintain the order of $\Delta$ TSP values in the downstream direction, so each site's tabular values were manually checked against their corresponding GIS pixel values. At some points along the stream channel where pixels did not strictly proceed in either a north-south or east-west direction, the exported tabular values were not properly ordered. In such instances, their order was corrected to reflect the proper downstream sequence of values. 


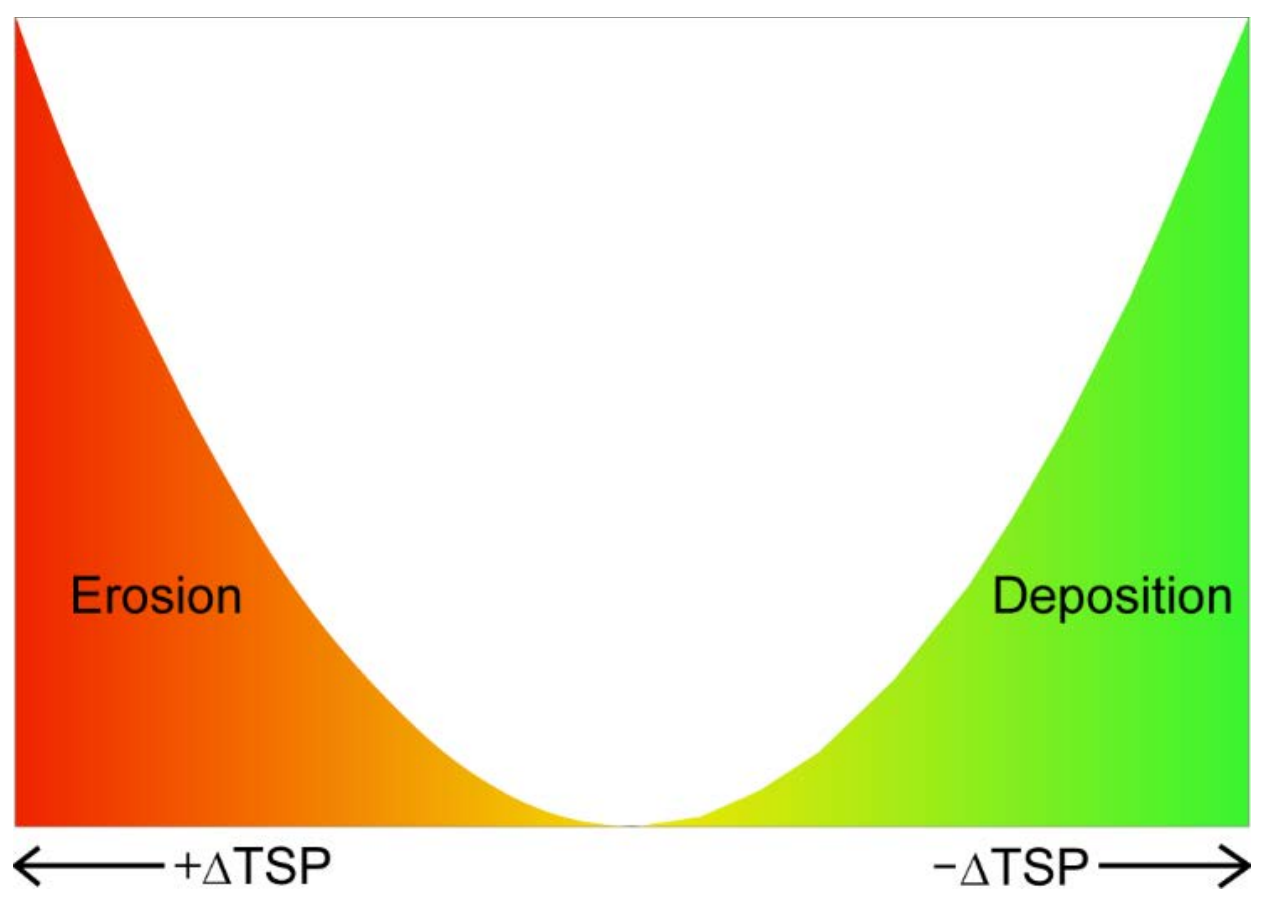

Figure 13. Illustration of the theoretical relationship between variation in $\triangle T S P$ and sediment response. Greater increases (+) in $\triangle T S P$ are expected to generate larger volumes of erosion, while greater decreases (-) in $\triangle$ TSP are expected to produce larger volumes of deposition (Source: Lea and Legleiter 2016).

\subsection{Statistical Methods}

Due to small sample size and non-normally distributed data, non-parametric statistical tests were used to analyze field and GIS-derived datasets. Depending on the variables of interest, one of three non-parametric tests (Wilcoxon Signed-Ranks Test, MannWhitney-Wilcoxon Test, or the Kruskal-Wallis Test) were used to test for significant difference among distributions. Spearman's Rank Test was used to quantify the extent and significance of correlation between different predictor variables and the response variable of $\mathrm{DsD}_{50}-\mathrm{UsD}_{50}$. Each statistical test was performed within the $\mathrm{R}$ statistical computing program (R Core Team, 2014).

Before performing statistical tests of difference and correlation, several variables needed to be defined and/or classified. The variables of check dam type, age, and condition 
were separated into discrete classes (Table 6), however, due to small sample size each of these did not yield significant differences with their corresponding $\mathrm{DsD}_{50}-\mathrm{UsD}_{50}$ values. Three other variables—Strahler stream order, geomorphic unit, and depositional unit—were used in analyzing optimal check dam locations. The geomorphic unit assigned to each check dam location is a function of $\Delta \mathrm{TSP}$, where positive $\Delta \mathrm{TSP}$ is represented by class one and negative $\triangle \mathrm{TSP}$ is represented by class two. Depositional unit is a subset of the second geomorphic unit, where class two represents areas that have both negative $\Delta$ TSP and are transitioning from positive to negative $\Delta \mathrm{TSP}$ (falling limb), and class one is all other areas.

First, the Wilcoxon Signed-Ranks Test was used to test for significant differences between paired downstream and upstream particle size distributions for all individual and aggregated check dams (Table 7). Next, Spearman’s Rank Test was used to correlate each continuous GIS-derived variable to $\mathrm{DsD}_{50}-\mathrm{UsD}_{50}$ (Table 8). The Mann-Whitney-Wilcoxon Test was used to test for significant differences between the medians of $\mathrm{DsD}_{50}-\mathrm{UsD}_{50}$ that fell into geomorphic units one and two. Similarly, the medians of $\mathrm{DsD}_{50}-\mathrm{UsD}_{50}$ that fell into depositional units one and two were tested for statistical difference using the MannWhitney-Wilcoxon Test. Lastly, because the sampled check dams fall into more than two classes of Strahler stream order, the Kruskal-Wallis Test was used to assess the statistical difference between medians of $\mathrm{DsD}_{50}-\mathrm{UsD}_{50}$ that fell into first, second, and third/fourth stream orders. See section 4.2 for graphical representations of the relationships between $\mathrm{DsD}_{50}-\mathrm{UsD}_{50}$ and geomorphic/depositional units, as well as Strahler stream order. 
Table 6. Classification of check dam type, age, and condition.

\begin{tabular}{llll}
\hline Class & Type & Age (years) & Condition \\
\hline 1 & Gabion & $<5$ & Unaltered functionality \\
2 & Rock & $5-10$ & Slightly compromised functionality \\
3 & Wood & $10-15$ & Heavily compromised functionality \\
4 & n/a & $15-20$ & n/a \\
\hline
\end{tabular}

Table 7. Field-derived variables for each check dam visited. $\mathrm{DsD}_{50}$ and $\mathrm{UsD}_{50}$ distributions found to be statistically different using the Mann-Whitney-Wilcoxon Test are shown with asterisks. Sample size (n) per individual $\mathrm{DsD}_{50} / \mathrm{UsD}_{50}=48$; sample size $(\mathrm{n})$ for aggregated $\mathrm{D}_{50}=21$. Check dam type, age, and condition are defined in Table 4.

\begin{tabular}{|c|c|c|c|c|c|c|c|}
\hline Check Dam ID & $\begin{array}{l}\mathrm{DsD}_{50} \\
(\mathrm{~mm})\end{array}$ & $\begin{array}{l}U_{s D_{50}} \\
(\mathrm{~mm})\end{array}$ & $\begin{array}{c}\mathrm{DsD}_{50}-\mathrm{UsD}_{50} \\
(\mathrm{~mm})\end{array}$ & $\begin{array}{l}\text { Local Channel } \\
\text { Width (m) }\end{array}$ & Type & Age & Condition \\
\hline Alcocer & 32.0 & 9.5 & $22.5^{* * *}$ & 6.7 & 2 & 1 & 2 \\
\hline Alonzo Yáñez U & 13.5 & 19.3 & -5.8 & 5.8 & 2 & 3 & 3 \\
\hline Alonzo Yáñez D & 45.0 & 4.0 & $41.0 * * *$ & 6.7 & 2 & 3 & 3 \\
\hline Augustín González $1 U$ & 11.0 & 2.0 & 9.0 & 9.1 & 2 & 2 & 1 \\
\hline Augustín González 1D & 45.0 & 2.0 & $43.0^{* *}$ & 8.5 & 2 & 2 & 1 \\
\hline Augustín González 2U & 16.0 & 3.4 & $12.6^{*}$ & 9.1 & 2 & 2 & 1 \\
\hline Augustín González 2D & 19.3 & 2.0 & $17.3^{* * *}$ & 8.8 & 2 & 2 & 1 \\
\hline Augustín González 3 & 45.0 & 16.0 & $29.0^{*}$ & 5.5 & 2 & 2 & 1 \\
\hline Cabras de Begoña U & 16.0 & 4.0 & $12.0 * * *$ & 6.1 & 2 & 3 & 1 \\
\hline Cabras de Begoña I & 38.5 & 2.0 & $36.5^{*}$ & 5.5 & 2 & 3 & 1 \\
\hline Cabras de Begoña D & 45.0 & 9.5 & $35.5^{* *}$ & 4.9 & 2 & 3 & 1 \\
\hline Estancia de Canal U & 64.0 & 4.8 & $59.2^{* * *}$ & 8.5 & 2 & 4 & 2 \\
\hline Estancia de Canal D & 54.5 & 16.0 & $38.5^{*}$ & 7.3 & 2 & 4 & 2 \\
\hline La Cruz del Palmar 1 & 16.0 & 8.0 & 8.0 & 7.0 & 1 & 1 & 1 \\
\hline La Cruz del Palmar 2 & 19.3 & 8.0 & $11.3^{* *}$ & 8.2 & 1 & 1 & 1 \\
\hline Fajardo de Támbula U & 8.0 & 2.0 & $6.0^{* * *}$ & 3.7 & 2 & 3 & 2 \\
\hline Fajardo de Támbula D & 54.5 & 4.0 & $50.5^{*}$ & 3.4 & 2 & 3 & 3 \\
\hline El Salitre U & 8.0 & 2.0 & $6.0^{*}$ & 4.9 & 3 & Not Known & 2 \\
\hline El Salitre D & 11.0 & 2.0 & $9.0^{* * *}$ & 4.9 & 3 & Not Known & 2 \\
\hline Sosnabar 1 & 16.0 & 4.0 & $12.0^{*}$ & 8.2 & 2 & 3 & 3 \\
\hline Sosnabar 2 & 3.4 & 2.0 & 1.4 & 1.9 & 2 & 3 & 3 \\
\hline Aggregated median & 19.3 & 4.0 & $15.3^{* * *}$ & $n / a$ & $\mathrm{n} / \mathrm{a}$ & $n / a$ & $n / a$ \\
\hline
\end{tabular}

* significant at $\mathrm{p}<0.05 ; * *$ significant at $\mathrm{p}<0.01 ; * * *$ significant at $\mathrm{p}<0.001$ 


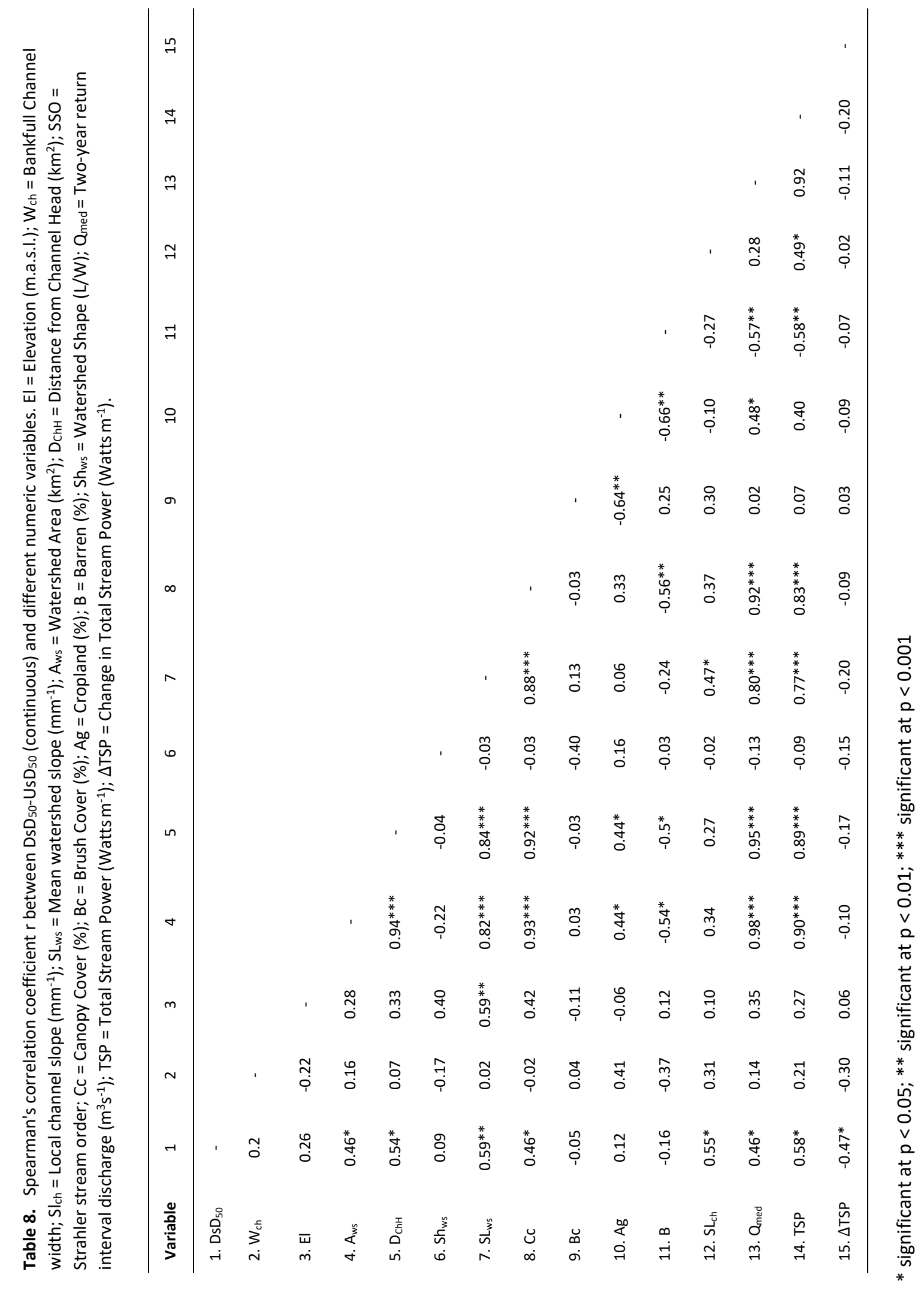




\subsection{Methodological Limitations}

The pebble count method provides insight into surface grain sizes, although it does not offer any information about the grain sizes of subsurface sediments or give any volumetric information. Therefore, the results that stem from the field methods used in this study are limited to what may be inferred by the size of channel bed surface particles.

There are several factors that control the accuracy of estimated TSP values using the above GIS methodologies. One of the more considerable limitations is a direct function of stream gauge data availability from within the region of interest. The past and present network of stream gauge stations in Central México is lacking in quantity, while most of the stream gauge stations located in upstream reaches relative to downstream reaches have rather short periods-of-record. As a result, there are very few gauge stations within the CI that satisfy the watershed size criteria of this study and are of a reasonably lengthy periodsof-record. Another important control factor on model accuracy is DEM resolution. The estimated channel slope and drainage area values included in the stream power model are ultimately a function of how well the DEM represents the real world elevation values. Barker et al. (2009) concluded that DEMs with a five-meter horizontal grid and a vertical accuracy of 0.5 meters offer slope estimates which correlate well with field measurements. This study uses an airborne LiDAR-derived DEM with five-meter horizontal resolution and one-meter vertical resolution (INEGI 2014). It should be noted, however, that DEMs derived from Terrestrial Laser Scanning (TLS) or Structure-from-Motion (SfM) technologies could potentially provide more accurate channel dimension calculations. A site-scale study such as this would stand to benefit from the higher accuracies that can be obtained from such technologies. For example, obtaining a DEM with sub-meter horizontal accuracy would 
allow for the calculation of continuous bankful channel width, which in turn would enable the calculation of continuous specific stream power. 


\section{Results}

\subsection{Check dam effectiveness}

Individually, $86 \%$ of check dams surveyed had statistically significant differences between opposing $\mathrm{DsD}_{50}$ and $\mathrm{UsD}_{50}$ distributions $(\mathrm{p}<0.05)$. The aggregate $\mathrm{DsD}_{50}$ and $\mathrm{UsD}_{50}$ distributions for all 21 check dams were found to be statically different $(\mathrm{p}<0.001)$. The aggregated median of all $\mathrm{DsD}_{50}-\mathrm{UsD}_{50}$ values is $15.3 \mathrm{~mm}$, indicating that the overall sample of check dams measured have been moderately effective at retaining entrained sediments. The aggregated distribution of downstream particle sizes is trimodal, with $38 \%$ of all particle sizes falling into either the 2,16, or 180 class (Figure 13). The aggregated upstream distribution, on the other hand, is strongly unimodal, with nearly $45 \%$ of all particle sizes contained within the 2-mm class (Figure 14).

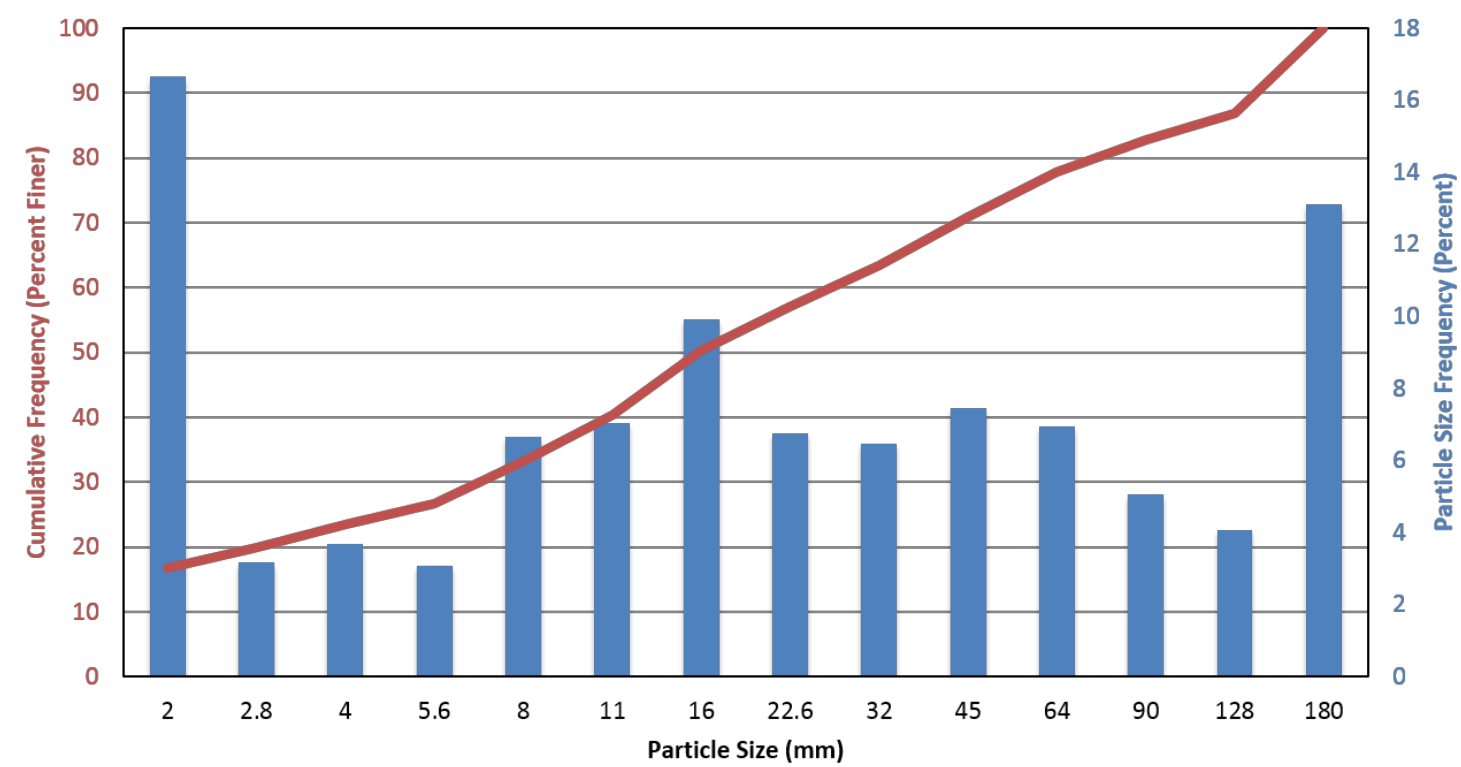

Figure 13. Cumulative frequency distribution of aggregated particle sizes measured downstream of check dams. 


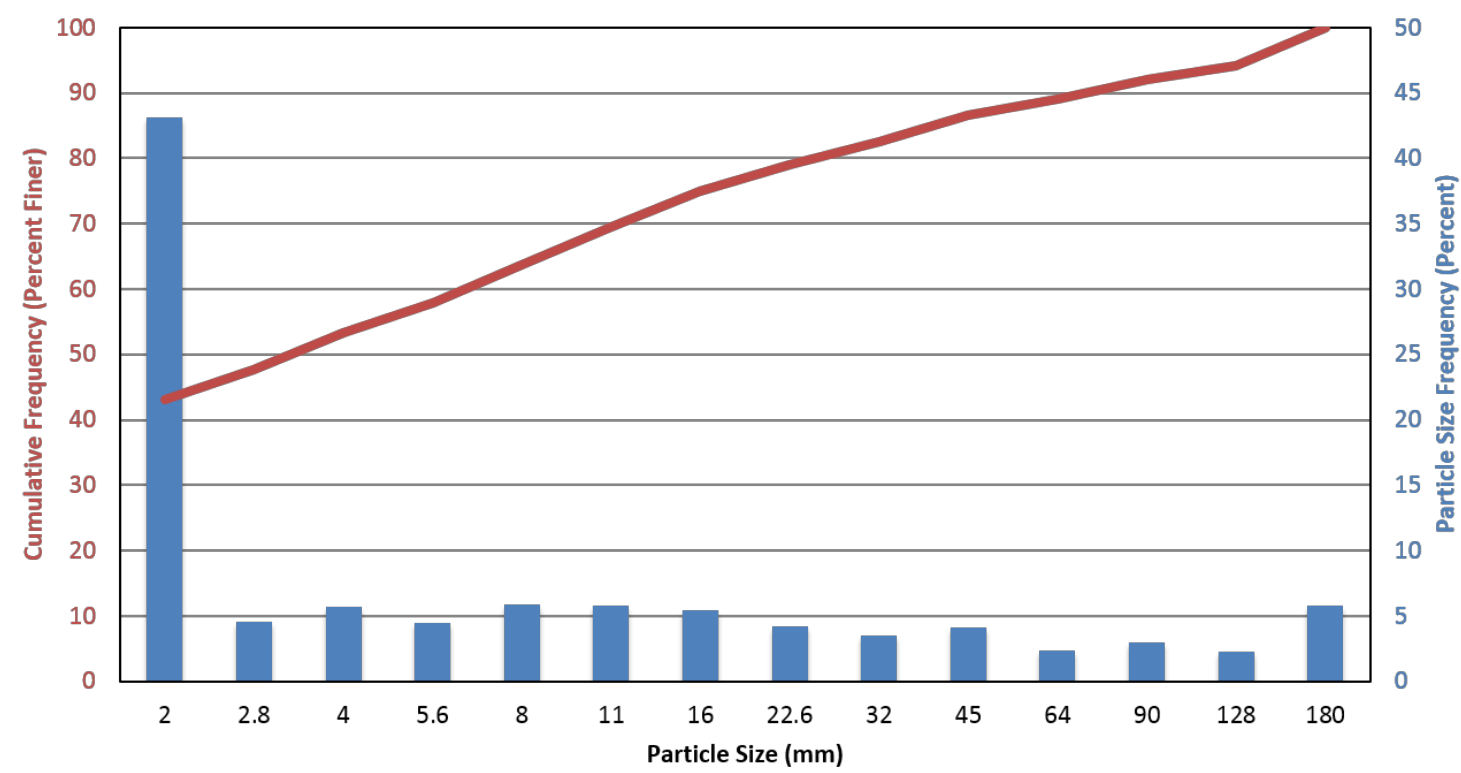

Figure 14. Cumulative frequency distribution of aggregated particle sizes measured upstream of check dams.

Further evaluation of the aggregated upstream and downstream particle size distributions reveals two noteworthy trends. First, there is no unidirectional trend in the downstream transect $\mathrm{D}_{50}$ values taken from sample one (closest to each check dam structure) to sample 16 (furthest from check dam structure). However, for upstream transect $\mathrm{D}_{50}$ values there is a general trend of increasing particle size with distance from check dam (Figure 15). This data inference is in accord with standard geomorphologic reasoning from research done on the effects of dams on sediment transport dynamics (e.g. Lancaster and Grant 2006)—namely that longitudinal alluviation upstream from a channel barrier diminishes with distance from the obstruction. The length of impounded sediment $\left(l_{i s}\right)$ directly upstream from a check dam is a function of three parameters: i) check dam height $\left(h_{c d}\right)$; ii) underlying channel surface gradient $(S)$; and iii) surface gradient of impounded sediment $\left(S_{1}\right)$. Figure 16 illustrates the relationship among these parameters. 


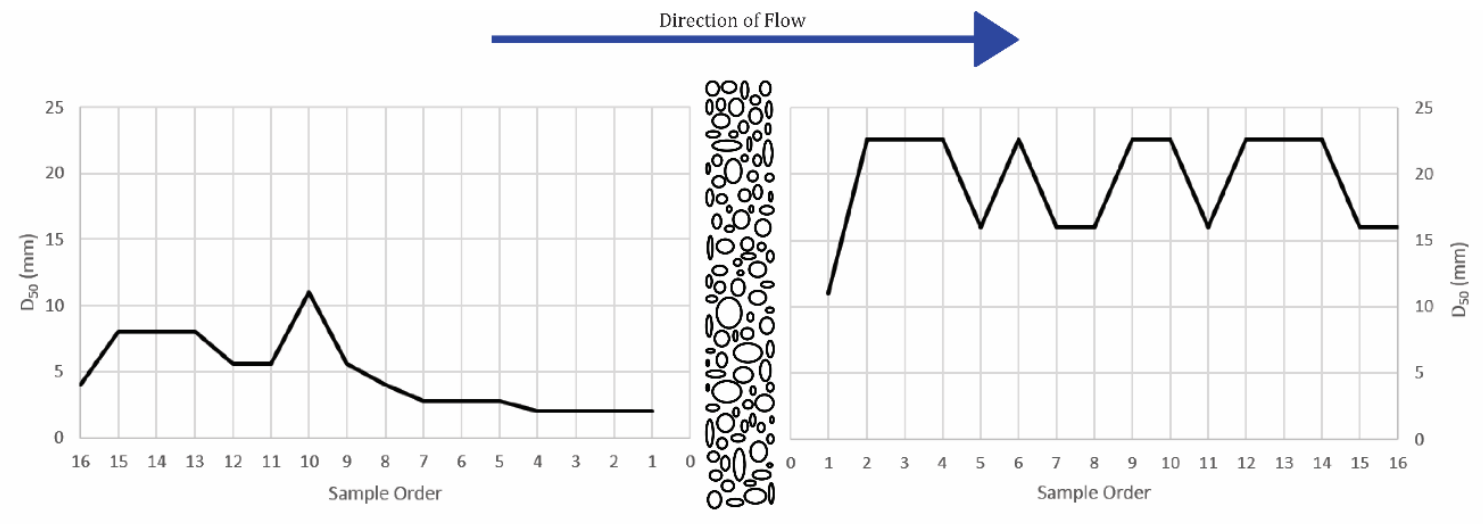

Figure 15. Distribution of particle sizes aggregated by order of sample taken for all upstream and downstream transects.

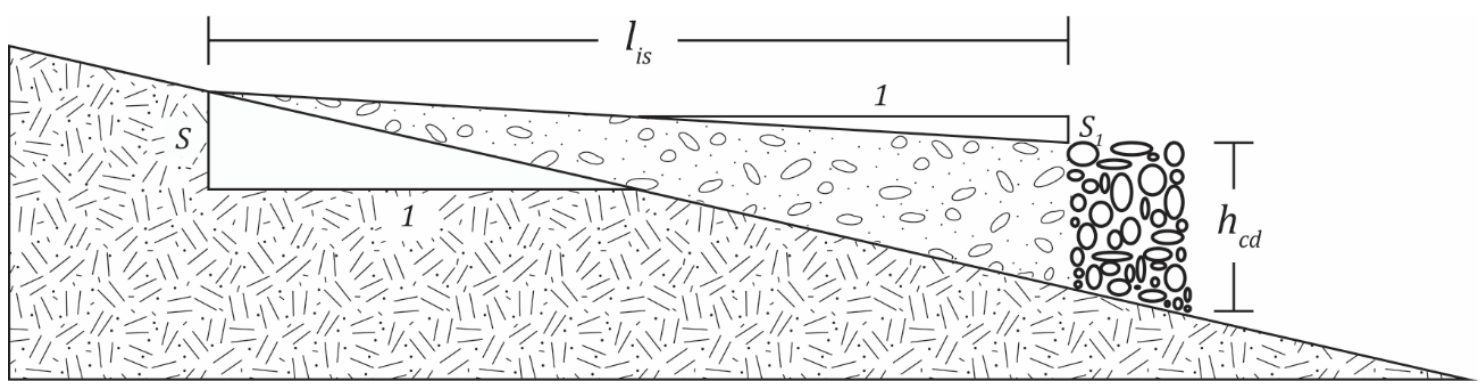

Figure 16. Schematic profile showing the alluvial effect of a check dam. The point of transition from the surface gradient of impounded sediment $\left(S_{1}\right)$ back to the underlying channel surface gradient $(S)$ migrates upstream with time after check dam installation. Eventually, at the upstream elevation of check dam height $\left(h_{c d}\right)$, upstream migration ceases and the length of impounded sediment terminates until either the check dam is removed or its height is extended.

The particle size data aggregated by individual upstream transects $(25 \%-4 \mathrm{~mm}, 50 \%$ $2.8 \mathrm{~mm}$, and $75 \%-4 \mathrm{~mm}$ ) are closely grouped, indicating that the latitudinal particle size differences are minimal. This consistency between particle sizes across the upstream channel bed could be a result of the alluviation caused by check dams, whereas the larger spread between the $\mathrm{D}_{50}$ values of downstream-aggregated individual transects $(25 \%$ - $22.6 \mathrm{~mm}, 50 \%$ $22.6 \mathrm{~mm}$, and 75\%-16 mm) may be explained by a lack of alluviation. 


\subsection{Controls on check dam effectiveness}

The variation in $\mathrm{DsD}_{50}-\mathrm{UsD}_{50}$ shows that the geophysical control factors influencing erosion-deposition dynamics within the fluvial setting are not spatially homogeneous. Furthermore, the spatial heterogeneity of these geophysical controls may explain the observed variation in $\mathrm{DsD}_{50}-\mathrm{UsD}_{50}$. The control factors that are proposed as influential to the observed variation in $\mathrm{DsD}_{50}-\mathrm{UsD}_{50}$ between check dams are listed in Tables 4 and 7 . The quantitative variables of local channel slope, mean subwatershed slope, subwatershed area, distance from channel head, canopy cover, $\mathrm{Q}_{\text {med, }}$ TSP, and $\Delta$ TSP were significant at the 5\% significance level.

Several statistical inferences emerge from the above correlation coefficients. First, higher local channel slope gradients and higher mean watershed slope gradients correlate with higher $\mathrm{DsD}_{50}-\mathrm{UsD}_{50}$ values. The least functional one-third of check dams have an average local channel slope value of $.03 \mathrm{~m} \mathrm{~m}^{-1}$, while the most functional one-third have an average local channel slope value of $.06 \mathrm{~m} \mathrm{~m}^{-1}$. This indicates that check dam effectiveness is at least partially dependent on local slope gradients that are steep enough to induce sediment transportation. Subwatershed area, distance from channel head, and $\mathrm{Q}_{\mathrm{med}}$, which are related measures, are positively correlated with $\mathrm{DsD}_{50}-\mathrm{UsD}_{50}(r=0.59, \mathrm{r}=0.54$, and $\mathrm{r}=0.46$, respectively). This pattern indicates that check dams located lower in a subwatershed are more effective at retaining sediment than those located closer to where channel heads develop.

Another noteworthy statistical result is the relationship between canopy cover and check dam functionality. The results of the correlation analysis indicate that higher percentages of canopy cover correlate with check dams that are more efficient at retaining 
sediment. The least functional one-third of check dams have subwatersheds with an average of $15 \%$ canopy cover. The seven top-performing check dams, however, have subwatersheds with an average of $28 \%$ canopy cover. Similarly, higher TSP $(r=0.58)$ values are correlated with higher $\mathrm{DsD}_{50}-\mathrm{UsD}_{50}$ values. The seven highest functioning check dams have an average TSP of $64 \mathrm{~W} \mathrm{~m}^{-1}$, while the lowest performing one-third of check dams have an average TSP of $17 \mathrm{~W} \mathrm{~m}^{-1}$. Lastly, $\Delta \mathrm{TSP}$ has a negative correlation with $\mathrm{DsD}_{50}-\mathrm{UsD}_{50}(\mathrm{r}=-0.45)$. As detailed in section 3.3, $\Delta$ TSP can be classified to further analyze the erosional and depositional dynamics along a stream channel.

With few exceptions, the 11 check dams classified as being within depositiondominated reaches $(-\Delta \mathrm{TSP})$ are those that are higher performing. As shown in Figure 17, the median of $\mathrm{DsD}_{50}-\mathrm{UsD}_{50}$ values from check dams in geomorphic unit one $(9 \mathrm{~mm})$ is statistically different from the median from check dams in geomorphic unit two $(29 \mathrm{~mm})$ (p $<0.05$ ). Of the 21 check dams evaluated, six (Alcocer, Alonzo Yáñez B, Augustin González 2A, Cabras de Begoña B, Estancia de Canal A and B) were classified within depositional unit two. As shown in Figure 18, the median of $\mathrm{DsD}_{50}-\mathrm{UsD}_{50}$ values from this subset of check dams $(37.5 \mathrm{~mm})$ is statistically different from the median of check dams in depositional unit one $(11.3 \mathrm{~mm})(\mathrm{p}<0.05)$. Figure 19 shows the median of $\mathrm{DsD}_{50}-\mathrm{UsD}_{50}$ values for check dams located in first $(9 \mathrm{~mm})$, second $(36.5 \mathrm{~mm})$, and third/fourth $(17.3 \mathrm{~mm})$ order streams $(\mathrm{p}<0.05)$. The check dams located in second order streams were most effective at retaining sediment, while those that are located in first order streams were least effective. 


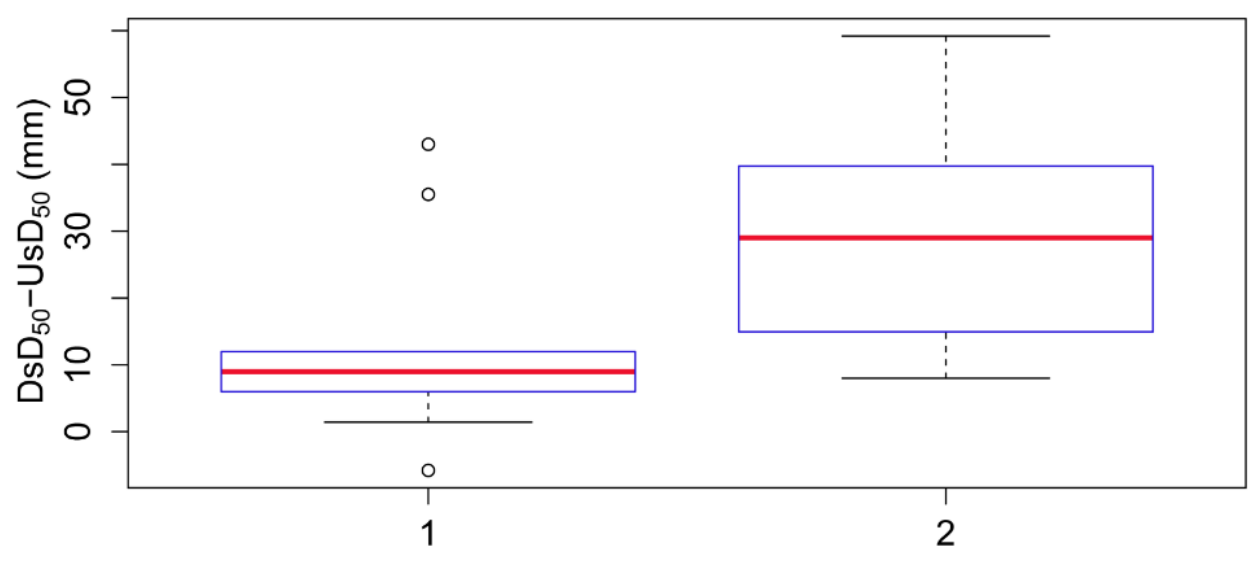

Geomorphic Unit

Figure 17. Plot of the relationship between $\mathrm{Ds}_{50}-U_{s D_{50}}$ and geomorphic unit as classified by $\triangle T S P$ for all measured check dams. The distribution of $\mathrm{DsD}_{50}-\mathrm{Us}_{50}$ for check dams found in erosion-dominated reaches (1) is generally lower than that of its deposition-dominated (2) counterparts.

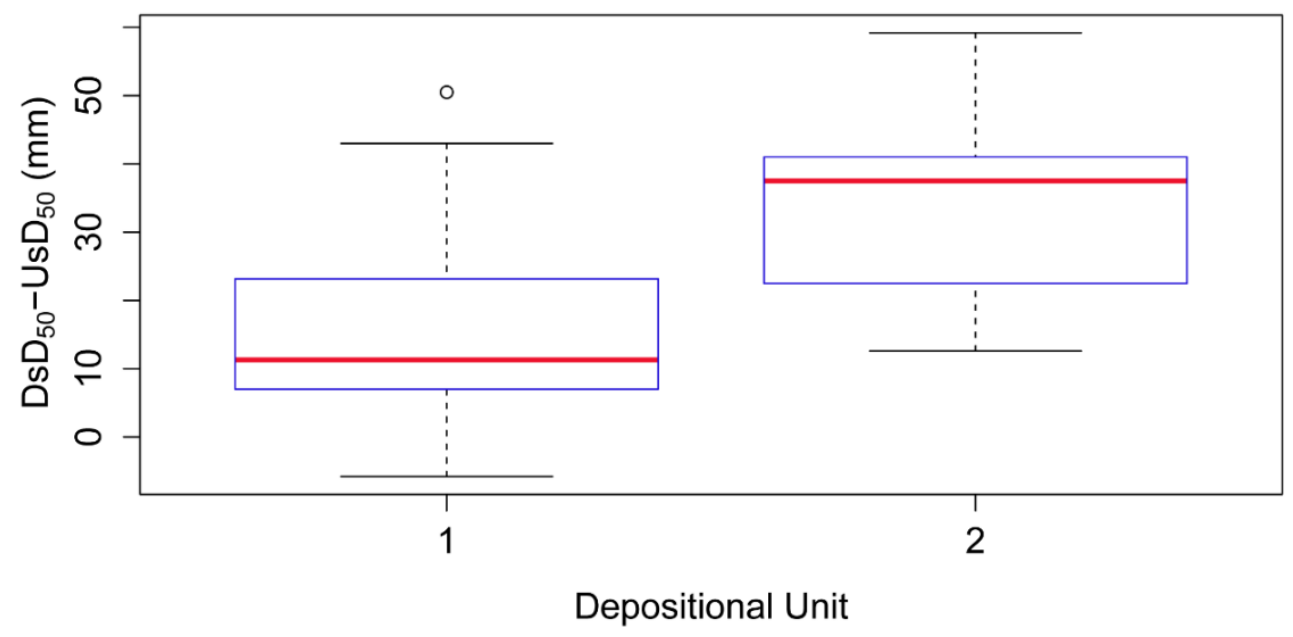

Figure 18. Plot of the relationship between $\mathrm{Ds}_{50}-\mathrm{Us}_{50}$ and depositional unit as classified by $\triangle T S P$ for all measured check dams. The distribution of $\mathrm{DsD}_{50}-\mathrm{UsD}_{50}$ for check dams found in areas of decreasing $\triangle T S P$ and have an associated negative $\Delta$ TSP value (2) is generally higher than that of check dams that do not meet this criteria (1). 


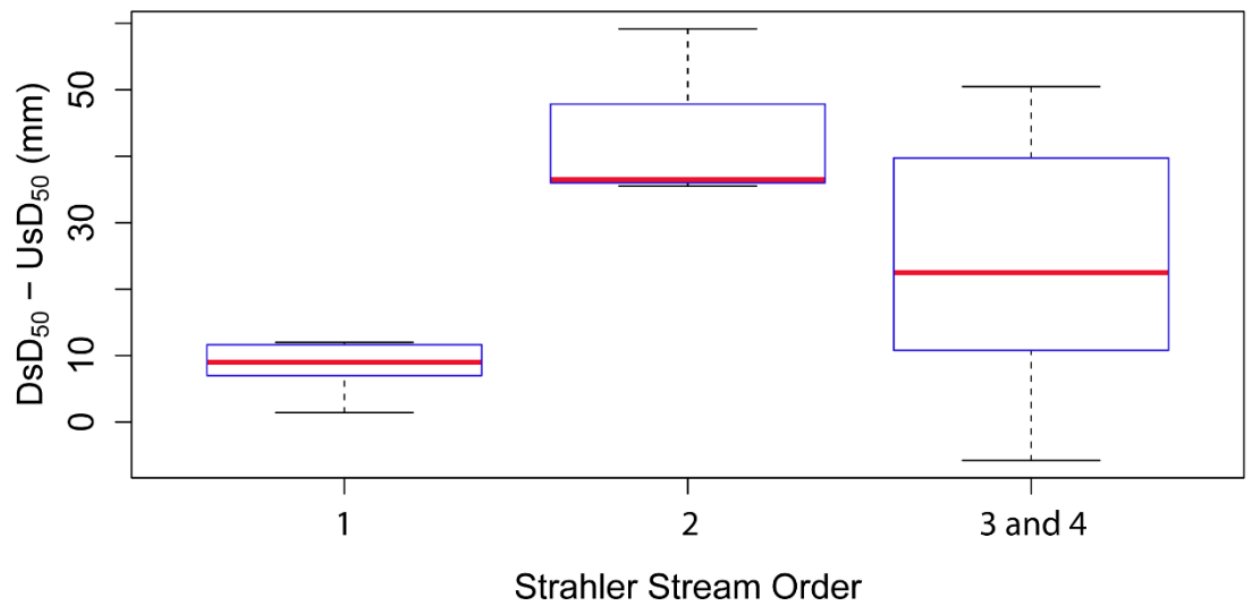

Figure 19. Plot of the relationship between $\mathrm{Ds}_{50}-U_{s} \mathrm{D}_{50}$ and Strahler stream order for all measured check dams.

\subsection{Individual Change in Stream Power Profile Analysis and Stream Power Maps}

The change in stream power profiles found in Appendix B illustrates the relationship between individual $\mathrm{DsD}_{50}-\mathrm{UsD}_{50}$ and $\Delta \mathrm{TSP}$ for each study site. Although some sites lack a comparability within the same profile (only one check dam was measured), there are some notable results. Figure B2 shows that for the two check dams measured within Alonzo Yáñez, the one located in a deposition-dominated reach has a higher $\mathrm{DsD}_{50}-\mathrm{UsD}_{50}$ value than the check dam located in an erosion-dominated reach. The same trend is true for the two check dams measured within Fajardo de Támbula (Figure B10). Both of the check dams measured in Estancia de Canal have moderate-to-high $\mathrm{DsD}_{50}-\mathrm{UsD}_{50}$ values and both are located within deposition-dominated reaches (Figure B7). These examples support the hypothesis that a check dam located within a deposition-dominated reach will function at a higher level than one located within an erosion-dominated reach. The three check dams 
within Cabras de Begoña offer a good spread in terms of $\Delta$ TSP and the trend is favorable towards rejecting the null hypothesis, although the difference between the $\mathrm{DsD}_{50}-\mathrm{UsD}_{50}$ values of check dam B and C is minor (Figure B6). Similarly, Augustin González 1 and 2 (Figures B3 and B4) indicate results that are not entirely consistent with rejecting the null hypothesis. Both of the check dams in Augustin González 1 are located within erosiondominated reaches, but only one is functioning at the expected lower level; the other has a relatively high $\mathrm{DsD}_{50}-\mathrm{UsD}_{50}$ value. The two check dams within Augustin González 2 have moderate $\mathrm{DsD}_{50}-\mathrm{UsD}_{50}$ values, with the higher one being associated with the check dam that is nearer to the erosion-dominated area on the graph. Both of the check dams within Salitre are within erosion-dominated reaches, but both also have low $\mathrm{DsD}_{50}-\mathrm{UsD}_{50}$ values.

All other stream power profiles have one check dam associated with them-Alcocer, Augustin González 3, La Cruz del Palmar 1 and 2, and Sosnabar 1 and 2-and therefore do not offer an intra-profile comparison. Although inferences from these sites do not lend themselves to individual site comparative analysis, they do provide additional information about the general relationship between $\Delta$ TSP and check dam performance. Both Alcocer and Augustin González 3 have moderate $\mathrm{DsD}_{50}-\mathrm{UsD}_{50}$ values and both are located within deposition-dominated reaches. The check dams at La Cruz del Palmar 1 and 2 and Sosnabar 1 and 2 all have relatively low $\mathrm{DsD}_{50}-\mathrm{UsD}_{50}$ values, but three of these four are located in deposition-dominated reaches. However, this can be explained by their relatively low absolute TSP values or lack of diversity in TSP.

In interpreting the stream power profiles in Appendix B, one notable distinction is distance from channel head. In general, check dams near their channel head have relatively low $\mathrm{DsD}_{50}-\mathrm{UsD}_{50}$ values (Cabras de Begoña A, La Cruz del Palmar 1 and 2, Salitre A and B, 
and Sosnabar 1 and 2). Check dams at other sites located further downstream generally have higher $\mathrm{DsD}_{50}-\mathrm{UsD}_{50}$ values (Alcocer, Alonzo Yáñez B, Augustin González 1B, Cabras de Begoña B and C, Estancia de Canal A and B, and Fajardo de Támbula B). Furthermore, Spearman's rank correlation coefficient between $\mathrm{DsD}_{50}-\mathrm{UsD}_{50}$ and distance from channel head was relatively strong $(r=0.54)$ and statistically significant at the $5 \%$ significance level.

The change in stream power maps found in Appendix $C$ were generated by performing the GIS workflow shown in Figure 8. The stream channel cells representing $\Delta \mathrm{TSP}$ were then separated into six equal interval classes representing the erosion-todeposition continuum. The maps show the spatially distributed $\Delta \mathrm{TSP}$ values at $\mathrm{Q}_{\mathrm{med}}$ for each site. Deposition-dominated reaches are shown in green and yellow; erosion-dominated reaches are shown in red (shades of yellow and orange may be considered areas where sediment is in transportation). The black point found along the $\Delta$ TSP gradient represent the locations of check dams that were measured in the field.

\subsection{Sensitivity Analysis of $\Delta$ TSP Methodology}

In the present study, the methods used to derive $\Delta$ TSP were selected based on those used by Bizzi and Lerner (2015) and matched to the scale of the subwatersheds of interest within the Rio Laja basin. Still, it is important to consider how alternative methods affect study outputs. The choice of neighborhood size (see Figure 12) for calculating TSP $_{\text {local }}$ and TSP $P_{u p}$ has a direct impact on $\Delta$ TSP. This section explores how changes in these neighborhood sizes affect the $\Delta \mathrm{TSP}$ values that were statistically compared with explanatory variables and ultimately used to create stream power maps. In addition to the value obtained for $T S P_{u p}$ using a 60-meter neighborhood size, values for TSP $P_{u p}$ using 30 and 15 meter 
neighborhoods were calculated. Two representative, yet contrasting subwatersheds-Alcocer and Farjado Tambula—were selected for applying the alternative neighborhood sizes. At 2.6 $\mathrm{km}^{2}$, Alcocer is the largest and steepest subwatershed in the study area. Fajardo de Tambula is half the size of Alcocer and although moderately steep has an average TSP value of $28 \mathrm{~W}$ $\mathrm{m}^{-1}$. Alcocer's average TSP is nearly four times that of Fajardo de Tambula, or $125 \mathrm{~W} \mathrm{~m}^{-1}$. Change in TSP was recalculated using the 30 and $15-\mathrm{m}$ neighborhoods for TSP $_{u p}$ for each subwatershed, and the resulting distributions were checked against the originally calculated $\Delta$ TSP distribution that used a $60-\mathrm{m}$ neighborhood for $T S P_{u p}$. Statistically significant differences were found at the 5\% significance level.

When considering the size of neighborhood to use in a given spatial analysis, there are two primary factors of interest: scale and resolution (i.e., size of watershed, and spatial resolution of data inputs). How these two factors relate to each other is of greatest significance. In general, when using the mean as the neighborhood statistic, larger neighborhoods result in smoother distributions. Reductions in noise enable the user to potentially capture more generalized patterns that would have otherwise gone unnoticed. This smoothing effect is illustrated for the Alcocer subwatershed in Figure 20. 


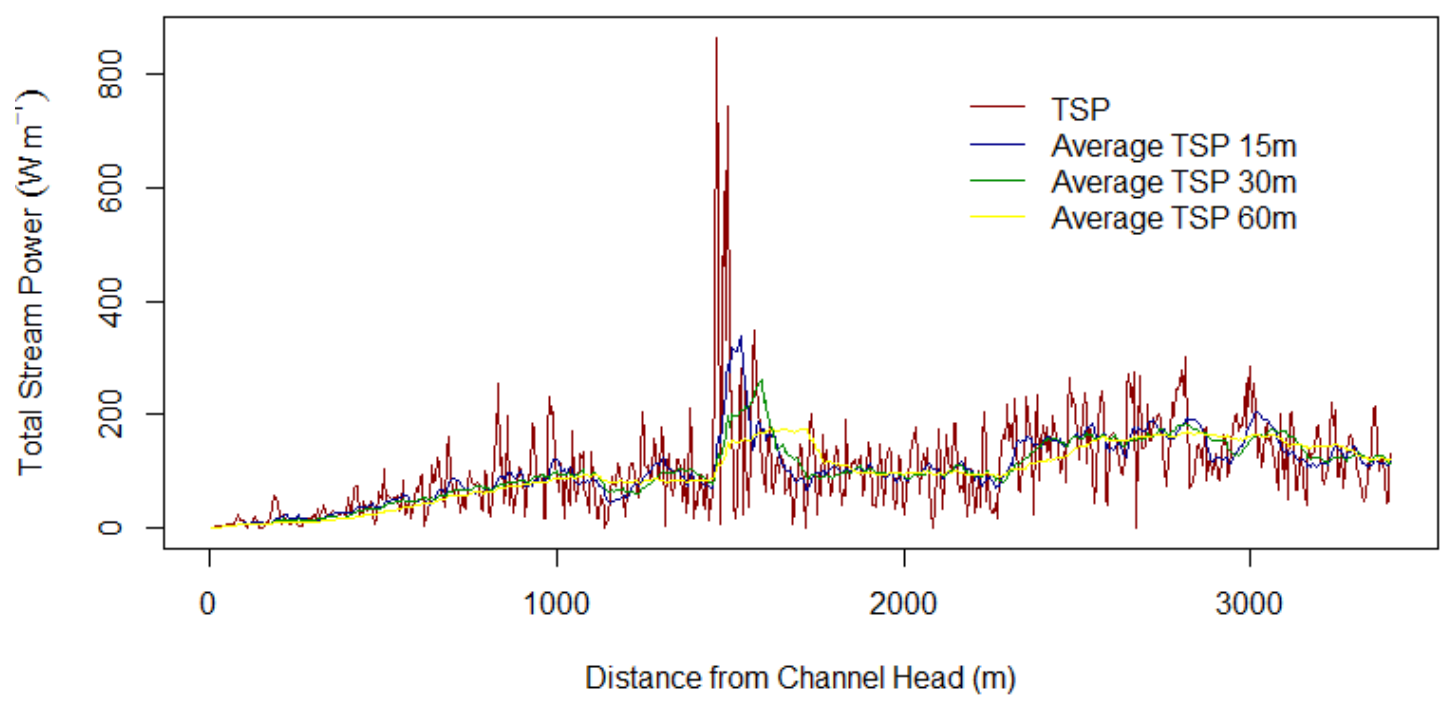

Figure 20. Comparison of TSP values associated with different neighborhood sizes for the Alcocer subwatershed.

The Wilcoxon Signed-Ranks Test was used to test for significant differences between paired $\Delta$ TSP distributions that were derived from using different size neighborhoods for $T S P_{u p}$. For both subwatersheds, the $\mathrm{p}$ values indicate non-identical populations between the $\mathrm{Up}_{15} / \mathrm{Up}_{60}$ and $\mathrm{Up}_{30} / \mathrm{Up}_{60}$ distributions (Figure 21). As anticipated, from these tests, it is concluded that neighborhood size has an important influence on the distribution of $\triangle T S P$ values along stream channels. More specifically, as TSP $P_{u p}$ neighborhood sizes increase, the $\Delta$ TSP distribution mean also increases. In the context of this study, this equates to less of the stream channel being classified as depositional (i.e., there are fewer negative values). Using larger $T S P_{u p}$ neighborhood sizes in relation to $T S P_{\text {local }}$ neighborhood sizes yields a stream power map that limits depositional reaches to those that are most likely to be truly depositional. In choosing a larger $T_{S} P_{\text {local }}$ neighborhood size, this study offers a conservative estimate of the areas within stream channels that qualify as depositional. Rather than 
overestimating the areas in which check dams are recommended to be built, this model output is desirable because it airs on the side of underestimating areas that qualify as depositional zones. Restoration managers are then more likely to find this study's check dam placement recommendations more reliable for attaining higher sediment retention rates than if a smaller TSP local neighborhood size was used.

Table 9. Distribution means and Wilcoxon Signed Rank test $\mathrm{P}$ values for $\Delta \mathrm{TSP}$ derived from alternative TSP up neighborhood sizes.

\begin{tabular}{|l|c|c|c|c|}
\hline \multirow{2}{*}{ Neighborhood Size } & \multicolumn{2}{|c|}{ Alcocer } & \multicolumn{2}{c|}{ Fajardo de Tambula } \\
\cline { 2 - 5 } & \multicolumn{2}{|c|}{$\Delta T S P$} & $\mu$ & $\mathrm{P}$ \\
\cline { 2 - 5 } & $\mu$ & $\mathrm{P}$ & .4 & $3.521 \mathrm{e}^{-05}$ \\
\hline $\mathrm{Up}_{15}$ & 1.6 & $1.316 \mathrm{e}^{-07}$ & 1.1 & $2.021 \mathrm{e}^{-08}$ \\
\hline $\mathrm{Up}_{30}$ & 2.9 & $7.852 \mathrm{e}^{-09}$ & 2.2 & - \\
\hline $\mathrm{Up}_{60}$ & 5.2 & - & & \\
\hline
\end{tabular}




\section{Discussion}

The literature reviewed in this study offers several alternative interpretations about where check dams should be located with respect to geomorphic and topographic variables. This is, in part, the case because each study area is comprised of different sets of these variables. Generally, although trade-offs exist for placing check dams in one location over another, this literature review suggests that check dams are more effective when located in second and third order streams (i.e., smaller drainage areas), and in lower gradient reaches (i.e., depositional zones) (Romero-Díaz, Alonso-Sarriá, and Martínez-Lloris 2007).

As explained by Chin and Wohl (2005), the evolution of a stream follows a trajectory characterized by various states of equilibrium and non-equilibrium (i.e., alternating levels of entropy). When assigning such characterizations, spatial and temporal scales are inherently important. Chaos may be fairly attributed to some reach of stream over a particular spatial extent and at a particular time; however, given a change in the temporal scale of analysis, that same reach may be entirely composed of regularly-spaced, regularly-sized steps and pools. Low frequency, high magnitude hydrologic events play an important role in the evolution of stream geomorphology by providing a reset function from which least-work principles inevitably reestablish themselves.

Naturally occurring step-pool sequences are spatially differentiated according to several variables, including channel slope, step height, step particle size, and channel width. For example, Wertz (1966) observed that within ephemeral streams in the Southwestern U.S., the length between sand patches and boulder steps are adjusted by channel slopeshorter in the headwaters and longer toward the valley plain. In the mountains of central 
Idaho, Chartrand and Whiting (2000) found positive correlations between step wavelength and step height $\left(r^{2}=0.93\right)$, step $D_{50}\left(r^{2}=0.72\right)$, and channel width $\left(r^{2}=0.73\right)$. Such spatial patterns should be recognized and applied within the context of the placement of manmade obstructions to stream flow. However, check dams placed within a stream channel should also be done so according to the unique geomorphic regimes of the watershed of interest. In addition to previously observed relationships between step wavelength and topographic/geomorphic variables, stream power modelling can aid in the understanding of energy fluxes that cause dynamic change in stream ecosystems. The location of deposition and erosion zones are direct outcomes of stream power (Talling and Sowter 1998), and can be modeled, as exemplified by the present study. Such locations can offer important information to stream restoration managers who are seeking a systematic approach to check dam placement.

Based on the performed statistical analysis, restoration managers should give consideration to locating future check dams in deposition-dominated stream reaches with the caveat that first order streams or those located nearest the channel head (i.e. low TSP values) should generally be avoided. Marston and Dolan (1999) reveal the result of poor check dam placement, finding that the majority of check dams within the Fifteen Mile Creek watershed were ineffective due to their placement in areas of low sedimentation. Similarly, Heede (1960) found that "where the magnitude of runoff and sediment production is small, as in the upper reaches of a watershed, the installation of numerous check dams is not justified." More specifically, the findings of this study suggest that areas of transition from erosional to depositional (decreasing $\Delta$ TSP) that coincide with areas of negative $\Delta T S P$ 
should be prioritized. Importantly, the optimal check dam location seems to be before the trough, or the point at which $\triangle \mathrm{TSP}$ reaches is local low.

Effective spacing between structures (e.g., head-to-toe rule) as recommended by Heede (1976) and strength/type of structure also must be considered within the context of check dam location. For example, steeper channel slopes will necessitate shorter spacing between structures, as can be observed within natural step-pool sequences. Step-pool frequency increases with increasing slope is now firmly established and supported by numerous field datasets from a variety of locations. and check dams located in higher order streams should be built with heavier materials. Gabiones should be considered where stream power values are sufficiently high. 


\section{Conclusions}

\subsection{Summary}

This study aimed to provide a field/GIS-based methodology for assessing the function and location of check dams constructed within the upland stream channels of the Upper Laja River watershed, Guanajuato, México. Results from the sample of check dams measured in the field indicate that, in general, the measured check dams are providing the intended function of sediment retention. The variability observed in the metric used to measure check dam effectiveness $\left(\mathrm{DsD}_{50}-\mathrm{UsD}_{50}\right)$ begged the question of what factors may be linked to check dam effectiveness. Stream power is one such factor, as its relationship to geomorphic change (e.g., channel erosion/deposition dynamics) is well-established (Lea and Legleiter 2016). In comparing the field data with data from the stream power model, spatially-distributed stream power does appear to influence a check dam's ability to retain

sediment—check dams located in deposition-dominated reaches (- $\Delta$ TSP) are not only more likely to be effective at sediment retention, but they are also more likely to maintain their structural integrity for a longer period of time than check dams built in erosion-dominated reaches.

It is important to note, however, that there seems to be a point of diminishing strength in the relationship between decreasing stream power and check dam effectiveness. If the channel slope and/or discharge at a check dam location is too low, its effectiveness will be compromised. This can be seen in the results from several of the check dams where low absolute TSP values and low $\mathrm{DsD}_{50}-\mathrm{UsD}_{50}$ values were found to coincide. As a result, in order to optimize the sediment retention potential of a check dam, this study indicated the 
importance of two criteria: i) absolute TSP must be sufficiently high to induce erosion (i.e. a stream reach of moderate to high sedimentation — usually a second or third order stream); and ii) within that moderate to high sedimentation zone, $\Delta$ TSP must be decreasing and negative (i.e. a deposition-dominated zone). Exceptions to these rules may exist in areas where other geophysical factors are particularly influential. For example, particularly erosionprone soils such as poorly-sorted conglomerates may lead to the occurrence of headcutting/gullying in first order streams or areas of low slope and/or discharge. In such cases, the mere presence of erosional features indicates that check dam construction would likely be beneficial.

In addition to stream power, other watershed factors may influence the effectiveness of check dams. Canopy cover, for example, was also found to correlate with higher functioning check dams. This may at first seem counterintuitive because higher percentages of canopy cover would seem to indicate healthier, less erosion-prone watershed conditions. However, one possible explanation for this correlation could be a survivorship bias- that is, check dams located in subwatersheds with higher percentages of vegetation tend to persist, while check dams located in less vegetated areas are subject to being washed away during high flow events.

Although a larger sample size of $\mathrm{DsD}_{50}-\mathrm{UsD}_{50}$ values taken from a more diverse set of check dam locations would likely yield more robust conclusions about where restoration managers should build check dams in the future, the results of this study show that placing check dams within specific ranges on the $\Delta$ TSP continuum can lead to optimized sediment retention. 


\subsection{Future Research}

This study demonstrated that total stream power can be a useful indicator of check dam effectiveness as defined by their ability to retain sediment. From this relationship, and the relationship between other watershed variables and measured check dam effectiveness, conclusions about optimal check dam placement within the stream channel are reached.

However, further research, in the form of larger sample sizes, is needed to confirm/expand on the link between spatially distributed stream power and check dam effectiveness. For example, monitoring the effectiveness of a large set of check dams over the course of several years and comparing the results to the $\Delta$ TSP values associated with those check dams would offer greater insight into the validity of the conclusions of this study. Furthermore, such a study may also yield more specific TSP and $\Delta$ TSP thresholds for optimizing check dam location.

Such thresholds will inevitably vary depending on the design flow used for locating check dams within the stream channel. Higher flows affect the spatial distribution of TSP/channel erosion and deposition, changing where a check dam may be most effective or endure for the intended period of time. Although outside the scope of this study, this tradeoff between optimizing check dam location for the purposes of sediment retention, and optimizing check dam location for longevity is an important consideration when designing watershed restoration projects such as those found in the Upper Laja River watershed. This study used a two-year flow, whereas other restoration projects may prefer to use a higher recurrence interval for their design flow depending on budget allowances for initial construction costs and future maintenance costs. Additional research focused on the 
opportunity costs associated with these tradeoffs would help to guide expectations for restoration managers and stakeholders.

The choice of spatial scale is an important consideration for any hydrological modelling exercise. Patterns of in-channel sediment erosion and deposition are particularly sensitive to the cell resolution used in a spatially distributed model. For example, for site scale studies such as this, it is important to use a high-resolution DEM to capture small increments of change in TSP. If modelled at the watershed scale, more generalized results would likely necessitate greater expertise in the field for deciding where to locate check dams.

Finally, because the optimal check dam location based on analysis from one watershed variable may not correspond with that of another watershed variable, it is important to more completely understand which variables are more or less influential to check dam effectiveness. If undertaken, the results of similar studies completed in a variety of watershed ecosystems would provide valuable information as to the applicability of TSP as a means to optimize check dam location and effectiveness. 


\section{References Cited}

Aalto, R, T. Dunne, and J. L. Guyot. 2006. Geomorphic controls on Andean denudation rates. Journal of Geology 114(1): 85-99.

Acosta, I. R., and M. J. Montero Martínez. 2014. Assessment of surface runoff vulnerability to climate change in the Lerma-Chapala Basin, México. Journal of Water Resources Planning and Management 140(12): 1-13.

Assouline, S., and M. Ben-Hur. 2006. Effects of rainfall intensity and slope gradient on the dynamics of interrill erosion during soil surface sealing. Catena 66: 211-220.

Baker, D. W., P. B. Bledsoe, C. M. Albano, and N. L. Poff. 2011. Downstream effects of diversion dams on sediment and hydraulic conditions of Rocky Mountain streams. River Research and Applications 27(3): 388-401.

Bombino, G., A. M. Gurnell, V. Tamburinoa, D.A. Zemaa, and S.M. Zimbone. 2008. Sediment size variation in torrents with check dams: Effects on riparian vegetation. Ecological Engineering 32: $166-77$.

Barker, D. M., D. M. Lawler. D. W. Knight, D. G. Morris, H. N. Davies, and E. J. Stewart. 2009. Longitudinal distributions of river flood power: the combined automated flood, elevation and stream power (CAFES) methodology. Earth Surface Processes and Landforms 34: 280-290.

Barrett, B. S., and M. I. Esquivel Longoria. 2013. Variability of precipitation and temperature in Guanajuato, México. Atmósfera 26(4): 521-536.

Bizzi, S., and B. N. Lerner. 2015. The use of stream power as an indicator of channel sensitivity to erosion and deposition processes. River Research and Applications 31: 16-27.

Brice, J. C. 1966. Erosion and deposition in the loess-mantled Great Plains, Medicine Creek drainage basin, Nebraska. Geological professional paper 352-H. Washington: U.S. Department of the Interior.

Bundt, K., and S. R. Abt. 2001. Sampling Surface and Subsurface Particle-Size Distributions in Wadable Gravel- and Cobble-Bed Streams for Analyses in Sediment Transport, Hydraulics, and Streambed Monitoring. United States Department of Agriculture (USGA). General Technical Report RMRS-GTR-74.

Burchsted, D., and M. D. Daniels. 2014. Classification of the alterations of beaver dams to headwater streams in northeastern Connecticut, U.S.A. Geomorphology 205: 36-50.

Butzer, K. W., and E. K. Butzer. 1997. The natural vegetation of the Mexican Bajío: archival documentation of a $16^{\text {th }}$-century savanna environment. Quaternary International 43-44: 161-72.

Castillo, V. M., W. M. Mosch, C. Conesa García, G. G. Barberá, J. A. Navarro Cano, and F. LópezBermúdez. 2007. Effectiveness and geomorphological impacts of check dams for soil erosion control in a semiarid Mediterranean catchment: El Cárcavo (Murcia, Spain). Catena 70: 416-27. 
Cerdá, A. 2002. The effect of season and parent material on water erosion on highly eroded soils in eastern Spain. Journal of Arid Environments 52: 319-37.

Chambers, K. J., and J. H. Momsen. 2007. From the kitchen and the field: gender and maize diversity in the Bajío region of México. Singapore Journal of Tropical Geography 28: 39-56.

Chartrand, S. M., and P. J. Whiting. 2000. Alluvial architecture in headwater streams with special emphasis on step-pool topography. Earth Surface Processes and Landforms 25: 583-600.

Chin, A. 1999. On the origin of step-pool sequences in mountain streams. Geophysical Research Letters 26(2): 231-34.

Chin, A. and J. Phillips. 2007. The self-organization of step-pools in mountain streams. Geomorphology 83(30): 346-58.

Chin, A. and E. Wohl. 2005. Toward a theory for step pools in stream channels. Progress in Physical Geography 39(3): 275-96.

Conesa-García, C. and R. García-Lorenzo. 2009. Effectiveness of check dams in the control of general transitory bed scouring in semiarid catchment areas (South-East Spain). Water and Environment Journal 23(1): 1-14.

Conoscenti, C., V. Agnesi, S. Angileri, C. Cappadonia, E. Rotigliano, and M. Märker. 2013. A GISbased approach for gully erosion susceptibility modelling: a test in Sicily, Italy. Environmental Earth Sciences 70: 1179-95.

CEAG (Comisión Estatal del Agua de Guanajuato). 1999. Manual de programas y servicios.

CNA (Comisión Nacional del Agua). 2015. Bases de Datos Hidrométricas. http://www.conagua.gob.mx/CONAGUA07/Contenido/Documentos/Portada\%20BAN DAS.htm (last accessed 25 November 2015).

CNA (Comisión Nacional del Agua). 2015. SIG BANDAS v. 1.0. http://hidrosuperf.imta.mx/bandas/ (last accessed 28 November 2015).

CNA (Comisión Nacional del Agua). 1997. Banco Nacional de Datos de Aguas Superficiales. CDROM 2:Región VIII (Lerma). Instituto Mexicano de Tecnología del Agua, Jiutepec, Morelos, México.

Daba, S. 2002. An investigation of the physical and socioeconomic determinants of soil erosion in the Hararghe Highlands, Eastern Ethiopia. Land Degradation \& Development 14: 69-81.

Dávila-Aranda, P., R. Lira-Saade, and J. Valdés-Reyna. 2004. Endemic species of grasses in México: a phytogeographic approach. Biodiversity and Conservation 13: 1101-21.

de Vente, J., and J. Poesen. 2005. Predicting soil erosion and sediment yield at the basin scale: scale issues and semi-quantitative models. Earth-Science Reviews 71: 95-125. 
Delong, S. B., J. P. L. Johnson, and K. X. Whipple. 2014. Arroyo channel head evolution in a flashflood-dominated discontinuous ephemeral stream system. Geological Society of America Bulletin 126(11/12): 1683-1701.

Doolittle, W. E. 1985. The Use of Check Dams for Protecting Downstream Agricultural Lands in the Prehistoric. Journal of Anthropological Research 41(3): 279-305.

Dottertweich, M. 2008. The history of soil erosion and fluvial deposits in small catchments of central Europe: deciphering the long-term interaction between humans and the environment-A review. Geomorphology 101: 192-208.

Dotterweich, M. 2013. The history of human-induced soil erosion: Geomorphic legacies, early descriptions and research, and the development of soil conservation-A global synopsis. Geomorphology 201: 1-34.

Douglas, M. W., R. A. Maddox, and K. Howard. 1993. The Méxican monsoon. Journal of Climate 6: 1665-77.

ESF (Ecosystem Sciences Foundation). 2013. Upper Laja River restoration geodatabase. 15 September, 2014.

Eitel, B., J. Eberle, and R. Kuhn. 2002. Holocene environmental change in the Otjiwarongo thornbush savanna (Northern Namibia): evidence from soils and sediments. Catena 47: 4362.

Eswaran, H., P. Reich, and F. Beinroth. 2001. Global desertification tension zones. Sustaining the Global Farm: tenth international soil conservation organization meeting. 24-28.

FAO (Food and Agriculture Organization of the United Nations). 2014. Annex 1: Types and forms of erosion by water and wind.

http://www.fao.org/fileadmin/templates/nr/kagera/Documents/LADA_manuals/part2_h .pdf (last accessed 5 December 2015).

FAO (Food and Agriculture Organization of the United Nations)/IIASA (International Institute for Applied Systems Analysis). 2008. Harmonized World Soils Database v 1.2. http://www.fao.org/soils-portal/soil-survey/soil-maps-and-databases/harmonized-worldsoil-database-v12/en/ (last accessed 6 December 2015).

Fencl, J. S., M. E. Mather, K. H. Costigan, and M. D. Daniels. 2015. How Big of an Effect Do Small Dams Have? Using Geomorphological Footprints to Quantify Spatial Impact of Low-Head Dams and Identify Patterns of Across-Dam Variation. PLoS one 10(11): e0141210.

Ferrari, L., S. Conticelli, G. Vaggelli, C. M. Petrone, and P. Manetti. 2000. Late Miocene volcanism and intra-arc tectonics during the early development of the Trans-Mexican Volcanic Belt. Tectonophysics 318: 161-85.

Ferrer-Polo, F. J. 1993. Recomendaciones para el cálculo hidrometeorológico de avenidas. Madrid: Ministerio de Obra Públicas, Transportes y Medio Ambiente, CEDES (Centro de Estudios y Experimentación de Obras Públicas).

Fox, G. A., and G. V. Wilson. 2010. The role of subsurface flow in hillslope and stream bank erosion: a review. Soil Science Society of America Journal 74: 717-33. 
Gabet, E. J., D. W. Burbank, B. Pratt-Sitaula, J. Putkonen, and B. Bookhagen. 2008. Modern erosion rates in the high Himalayas of Nepal. Earth and Planetary Science Letters 267: 482-494.

Garcia, E. 1964. Modificaciones al sistema de clasificación climática de Köppen. Instituto de Geografía Universidad Nacional Autónoma de México. Seria libros: Núm. 6.

Gellis, A. C., A. Cheama, V. Laahty, and S. Lalio. 1995. Assessment of gully-control structures in the Rio Nutria watershed, Zuni Reservation, New Mexico. Journal of the American Water Resources Association 31(4): 633-46.

Gesch, K. R., R. R. Wells, R. M. Cruse, H. G. Momm, and S. M. Dabney. 2015. Quantifying uncertainty of measuring gully morphological evolution with close-range digital photogrammetry. Soil Science Society of America 79: 650-59.

Gutiérrez J., and E. Solano. 2014. Afinidades florísticas y fitogeográficas de la vegetación del municipio de San José Iturbide, Guanajuato, México. Acta Botánica Mexicana 107: 27-65.

Hamdan, A., and J. C. Stromberg. 2016. Changes in riparian plant communities due to a canal barrier traversing ephemeral stream channels in the Sonoran Desert. Journal of Arid Environments 125: $1-7$.

Hassanli, A. M., A. E. Nameghi, and S. Beecham. 2009. Evaluation of the effect of porous check dam location on fine sediment retention (a case study). Environmental Monitoring and Assessment 152: 319-26.

He, X., J. Zhou, X. Zhang, and K. Tang. 2006. Soil erosion response to climatic change and human activity during the Quaternary on the Loess Plateau, China. Regional Environmental Change 6: 62-70.

Heede, B. H. 1960. A study of early gully-control structures in the Colorado Front Range. U.S. Department of Agriculture. Station paper no. 55.

Heede, B. H. 1976. Gully Development and Control. U.S. Department of Agriculture Research Paper RM-169, 40 pp.

Heede, B. H. 1979. Deteriorated watersheds can be restored: a case study. Environmental Management 3(3) 271-81.

IACWD. 1982. Guidelines for determining flood flow frequency. Bulletin \# 17B of the hydrology subcommittee.

INEGI. 2014. Productos: Modelos Digitales de Elevación da Alta Resolución LiDAR. http://buscador.inegi.org. $\mathrm{mx} / /$ search?q $=\&$ requiredfields $=\mathrm{cve}$ titgen:1013\&client=Product osR\&proxystylesheet=ProductosR\&num=10\&getfields $=* \&$ sort $=$ meta:edicion:D:E::.D\&ent $\mathrm{sp}=\mathrm{a}$ inegi politica $\mathrm{p} 72 \& \mathrm{lr}=$ lang $\mathrm{es} \%$ 7Clang en\&oe $=\mathrm{UTF}-8 \& \mathrm{\alpha ie}=\mathrm{UTF}$ -

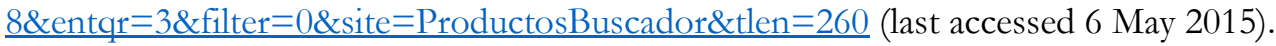

INEGI. 2015. Población, Hogares y Vivienda. http://www3.inegi.org. $\mathrm{mx} /$ sistemas/temas/default.aspx?s $=$ est\&c $=17484$ (last accessed 15 September 2015). 
Jain, V., N. Preston, K. Fryirs, and G. Brierley. 2006. Comparative assessment of three approaches for deriving stream power plots along long profiles in the upper Hunter River catchment, New South Wales, Australia. Geomorphology 74: 297-317.

Jin, Z., B. Cui, Y. Song, W. Shi, K. Wang, Y. Wang, and J. Liang. 2012. How Many Check Dams Do We Need To Build on the Loess Plateau? Environmental Science \& Technology 46: 8527-28.

Kedar, Y. 1957. Water and soil from the desert: some ancient agricultural achievements in the Central Negev. The Geographical Journal 123(2): 179-87.

Kondolf, G. M. 1997. Application of the pebble count: notes on purpose, method, and variants. Journal of the American Water Resources Association 33(1): 79-87.

Krause, A. K., S. W. Franks, J. D. Kalma, R. J. Loughran, and J. S. Rowan. 2003. Multi-parameter fingerprinting of sediment deposition in a small gullied catchment in SE Australia. Catena 53: $327-48$.

Lal, R. 2003. Soil erosion and the global carbon budget. Environmental International 29: 437-50.

Lal, R., and B. A. Stewart. 1990. Advances in soil science. New York: Springer-Verlag.

Lancaster, S. T., G. E. Grant. 2006. Debris dams and the relief of headwater streams. Geomorphology 82: 84-97.

Lázaro, R., F. S. Rodrigo, L. Gutiérrez, F. Domingo, and J. Puigdefábregas. 2001. Analysis of a 30year rainfall record (1967-1997) in semi-arid SE Spain for implications on vegetation. Journal of Arid Environments 48: 373-395.

Lea, D. M., and C. J. Legleiter. 2016. Mapping spatial patterns of stream power and channel change along a gravel-bed river in northern Yellowstone. Geomorphology 252: 66-79.

Lecce, S. A. 1997. Nonlinear downstream changes in stream power on Wisconsin's Blue River. Annals of the Association of American Geographers 87:3 471-86.

Lenzi, M. A. and F. Comiti. 2003. Local scouring and morphological adjustments in steep channels with check-dam sequences. Geomorphology 55: 97-109.

Liu, B. M., Y. Abebe, O.V. McHugh, A. S. Collick, B. Gebrekidan, and T. S. Steenhuis. 2008. Overcoming limited information through participatory watershed management: case study in Amhara, Ethiopia. Physics and Chemistry of the Earth 33: 13-21.

Magaña, V. O., J. L. Vázquez, J. L. Pérez, and J. B. Pérez. 2003. Impact of El Niño on precipitation in México. Geofísica Internacional 42(3): 313-30.

Maganda, C. 2003. The politics of regional water management: the case of Guanajuato, México. Journal of Environment \& Development 12(4): 389-413.

Mahlknecht, J., J. F. Schneider, B. J. Merkel, I. Navarro de León, and S. M. Bernasconi. 2004. Groundwater recharge in a sedimentary basin in semi-arid México. Hydrogeology Journal 12: 511-30. 
Manzano-Agugliaro, F., A. Zapata-Sierra, C. Fernández-Castañeda, A. García-Cruz, and Q. Hernández-Escobedo. 2015. Extreme rainfall relationship in México. Journal of Maps 11(3): 405-14.

Marañón, B. 2006. Tension between agricultural growth and sustainability: the El Bajío case, México. United Nations Development Programme: Human Development Report Office.

Marcus, A. W., R. A. Marston, C. R. Colvard Jr., and R. D. Gray. 2002. Mapping the spatial and temporal distributions of woody debris in streams of the Greater Yellowstone Ecosystem, USA. Geomorphology 44(3-4): 323-35.

Marston, R. A., and L. S. Dolan. 1999. Effectiveness of sediment control structures relative to spatial patterns of upland soil loss in an arid watershed, Wyoming. Geomorphology 31: 313-323.

Marston, R. A. 1982. The geomorphic significance of log steps in forest streams. Annals of the Association of American Geographers 72(2): 99-108.

Martín-Moreno, C., C. F. Hijano, J. F. M. Duque, J. Laronne. 2014. The Ribagorda sand gully (eastcentral Spain): Sediment yield and human-induced origin. Geomorphology 224: 122-38.

Martínez-Casasnovas, J. A., and M. C. Ramos. 2006. The cost of soil erosion in vineyard fields in the Penedés-Anoia Region (NE Spain). Catena 68: 194-99.

Marzolff, I., and J. B. Ries. 2007. Gully erosion monitoring in semi-arid landscapes. Zeitschrift für Geomorphologie 51(4): 405-25.

Mekonen, K., and G. B. Tesfahunegn. 2011. Impact assessment of soil and water conservation measures at Medego watershed in Tigray, northern Ethiopia. Maejo International Journal of Science and Technology 5(3): 312-30.

Mekonnen, M., S. D. Keesstra, J. E. Baartman, C. J. Ritsema, and A. M. Melessa. 2015. Evaluating sediment storage dams: Structural off-site sediment trapping measures in northwest Ethiopia. Cuadernos de Investigacion Geographica 41(1): 7-22.

Mercado-Silva, N., M. R. Helmus, and M. J. Vander Zanden. 2009. The effects of impoundment and non-native species on a river food web in Mexico's Central Plateau. River Research and Applications 25: 1090-1108.

Milliman, J.D., and J.P.M. Syvitski. 1992. Geomorphic/tectonic control of sediment discharge to the ocean: the importance of small mountainous rivers. Journal of Geology 100: 525-44.

Mishra, A., J. Froebrich, and P. W. Gassman. 2007. Evaluation of the SWAT model for assessing sediment control structures in a small watershed in India. Transactions of the ASABE 50(2): 469-77.

Mitchell, D. L., D. Ivanova, R. Rabin, T. J. Brown, and K. Redmond. 2002. Gulf of California sea surface temperatures and the North American Monsoon: mechanistic implications from observations. Journal of Climate 15(17): 2261-81. 
Montgomery, D.R., and M.T. Brandon. 2002. Topographic controls on erosion rates in tectonically active mountain ranges. Earth and Planetary Science Letters 201:

481-89.

Murphy, M. E. 1986. Irrigation in the Bajio region of colonial México. Boulder, CO: Westview Press.

Murty, J. V. S. 1998. Watershed management. New Delhi: New Age International.

Navarro de León, I., J. Gárfias-Soliz, and J. Mahlknecht. 2005. Groundwater flow regime under natural conditions as inferred from past evidence and contemporary field observations in a semi-arid basin: Cuenca de la Independencia, Guanajuato, México. Journal of Arid Environments 63: 756-71.

Norton, J. B., F. Bowannie, Jr., P. Peynetsa, Q. Quandelacy, and S. F. Siebert. 2002. Native American methods for conservation and restoration of semiarid ephemeral streams. Journal of Soil and Water Conservation 57(5): 250-58.

Novo, S., and G. B. Raga. 2013. The properties of convective storms in Central México: a radar and lightning approach. Atmósfera 26(4): 461-72.

Nyssen, J., M. Veyret-Picot, J. Poesen, J. Moeyersons, M. Haile, J. Deckers, and G. Govers. 2004. The effectiveness of loose rock check dams for gully control in Tigray, northern Ethiopia. Soil Use and Management 20: 55-64.

Oostwoud Wijden, D., and R. Bryan. 2001. Gully-head erosion processes on a semi-arid valley floor in Kenya: a case study into temporal variation. Earth Surface Processes and Landforms 26: 911-33.

Parker, C., T. R Colin, and N. J. Clifford. 2015. Development of STREAM: a reach-based stream power balance approach for predicting alluvial river channel adjustment. Earth Surface Processes and Landforms. 40(3): 403-413.

Patel, D. P., P. K. Srivastava, M. Gupta, and N. Nandhakumar. 2015. Decision support system integrated with Geographic Information System to target restoration actions in watersheds of arid environment: a case study of Hathmati watershed, Sabarkantha district, Gujarat. Journal of Earth System Science 124(1): 71-86.

Peralta-Hernández, A. R., R. C. Balling Jr., and L. R. Barba-Martínez. 2009. Comparative analysis of indices of extreme rainfall events: variations and trends from southern México. Atmósfera 22(2): 219-28.

Poesen, J., J. Nachtergaele, G. Verstraeten, and C. Valentin. 2003. Gully erosion and environmental change: importance and research needs. Catena 50: 91-133.

Polyakov, V. O., M. H. Nichols, M. P. McClaran, and M. A. Nearing. 2014. Effect of check dams on runoff, sediment yield, and retention on small semiarid watersheds. Journal of Soil and Water Conservation 69(5): 414-21.

Portanga, E. W., and P. R. Bierman. 2011. Understanding Earth's eroding surface with ${ }^{10} \mathrm{Be}$. GSA Today 21(8): 4-10. 
R Core Team (2014). R: A language and environment for statistical computing. R Foundation for Statistical Computing, Vienna, Austria. URL http://www.R-project.org/.

Razavi, T., and P. Coulibaly. 2013. Streamflow prediction in ungauged basins: review of regionalization methods. Journal of Hydrologic Engineering 18(8): 958-975.

Ries, J. B., and I. Marzolff. 2003. Monitoring of gully erosion in the Central Ebro Basin by large-scale aerial photography taken from a remotely controlled blimp. Catena 50: 309-28.

Romero-Díaz, A., F. Alonzo-Sarriá, and M. Martínez-Lloris. 2007. Erosion rates obtained from check-dam sedimentation (SE Spain). A muli method comparison. Catena 71: 172-78.

Ropelewski, C. F., D. S. Gutzler, R. W. Higgins, and C. R. Mechoso. 2005. The North American monsoon system. The Global Monsoon System: Research and forecast WMO Tech. Doc. 1266: 207-18.

Samuel, J., P. Coulibaly, and R. A. Metcalfe. 2011. Estimation of continuous streamflow in Ontario ungauged basins: comparison of regionalization methods. Journal of Hydrologic Engineering 16(5): 447-459.

Schaller, M., F. von Blackenburg, N. Hovius, P. W. Kubik. 2001. Large-scale erosion rates from in situ-produced cosmogenic nuclides in European river sediments. Earth and Planetary Science Letters 188: 441-58.

Schreiber, J. C. 2014. Evaluation of Social and Economic Impacts of Restoration Projects in the Upper Río Laja Watershed, Guanajuato, México. Unpublished manuscript.

Shieh, C., Y. Guh, and S. Wang. 2007. The application of range of variability approach to the assessment of a check dam on riverine habitat alteration. Environmental Geology 52(3): 427-435.

Showers, K.B. 2006. A history of African soil: perceptions, use and abuse. In: McNeill, J.R., Winiwarter, V. (Eds.), Soils and Societies: Perspectives from Environmental History. The White Horse Press, Isle of Harris, UK, pp. 118-176.

Shreve, R. L. 1966. Statistical law of stream numbers. Journal of Geology 74(1): 17-37.

Sivapalan, M., K. Takeuchi, S. W. Franks, V. K. Gupta, H. Karambiri, V. Lakshmi, X. Liang, J. J. McDonnell, E. M. Mendiondo, P. E. O’Connell. T. Oki, J. W. Pomeroy, D. Schertzer, S. Uhlenbrook, and E. Zehe. 2003. IAHS decade on predictions in ungauged basins (PUB), 2003-2012: shaping an exciting future for the hydrological sciences. Hydrological Sciences Journal 48(6): 857-880.

SMN. 2015. Discarga de datos. Ensenada-Tijuana. http://clicom-mex.cicese.mx/ (last accessed 25 July 2015).

Sran, D. S., S. S. Kukal, and M. J. Singh. 2011. Run-off and sediment yield in relation to differential gully-plugging schemes in micro-catchments of Shiwaliks in the lower Himalayas. Archives of Agronomy and Soil Science 58(11): 1317-27.

Stahl, M. 1993. Land degradation in East Africa. Ambio 22(8): 505-08. 
Talling, P. J., and M. J. Sowter. 1998. Erosion, deposition and basin-wide variations in stream power and bed shear stress. Basin Research 10: 87-108.

Tamene, L., S. J. Park, R. Dikau, and P. L. G. Vlek. 2006. Reservoir siltation in the semi-arid highlands of northern Ethiopia: sediment yield-catchment area relationship and a semi-quantitative approach for predicting sediment yield. Earth Surfaces Processes and Landforms 31: 1364-83.

Témez, J. R. 1987. Cálculo hidrometeorológico de caudales máximos en pequeñas cuencas naturales. Madrid: Dirección General de Carreteras, MOPU.

Torres-Benites, E., E. Mejía-Sáenz, J. Cortés-Becerra, E. Palacios-Vélez, and A. Exebio-García. 2005. Adaptation of a hydrological simulation model to the Río Laja watershed, Guanajuato, México. Agrociencia 39(5): 481-90.

TRMM (Tropical Rainfall Measurement Mission Project). 2016. Daily TRMM and Other Satellites Precipitation Product (3B42 V6 derived) http://disc.gsfc.nasa.gov/datacollection/TRMM 3B42 daily V6.shtml (last accessed 25 May, 2016).

UNEP (United Nations Environmental Program). 1986. Sands of change: why land becomes desert and what can be done about it. UNEP Brief \#2: United Nations Environment Programme. Nairobi, Kenya.

Valentin, C., J. Poesen, and Y. Li. 2005. Gully erosion: impacts, factors and control. Catena 63: 13253.

Vance, D., Bickle, M., Ivy-Ochs, S., Kubik, P.W., 2003. Erosion and exhumation in the Himalaya from cosmogenic isotope inventories of river sediments. Earth and Planetary Science Letters 206: 273-288.

Vandekerckhove, L., J. Poesen, D. Oostwoud Wijdenes, G. Gyssels. 2001. Short-term bank gully retreat rates in Mediterranean environments. Catena 44: 133-61.

Villaseñor, J. L. 2004. Los géneros de plantas vasculares de la flora de México. Boletín de la Sociedad Botánica de México 75: 105-35.

Wasson, R. J., G. Caitcheon, A. S. Murphy, M. McCulloch, and J. Quade. 2002. Sourcing sediment using multiple tracers in the catchment of Lake Argyle, Northwestern Australia. Environmental Management 29 (5): 634-46.

Wertz, J. B. 1966. The flood cycle of ephemeral mountain streams in the Southwestern United States. Annals of the Association of American Geographers. 54(4): 598-633.

Wester, P., E. Mollard, P. Silva-Ochoa, S. Vargas-Velázquez. 2009. From half-full to half-empty: the hydraulic mission and water overexploitation in the Lerma-Chapala basin, México. In River basin trajectories: societies, environments and development, ed. F. Molle and P. Wester, 75-98. Oxfordshire, U.K.: CAB International.

Wilcox, A. C., E. E. Wohl, F. Comiti, and L. Mao. 2011. Hydraulics, morphology, and energy dissipation in an alpine step-pool channel. Water Resources Research 47(7). 
Wischmeier, W. H., and D. D. Smith. 1978. Predicting rainfall erosion losses. Agricultural Handbook no. 537. U.S. Department of Agriculture: Science and Education Administration.

Wohl, E. E. and T. Grodek. 1994. Channel bed-steps along Nahal Yael, Negev desert, Israel. Geomorphology 9(2): 117-26.

Wolman, M. G. 1954. A method of sampling coarse river-bed material. Transactions of the American Geophysical Union 35(6): 951-956.

World Bank Climate Change Knowledge Portal. 2015. http://sdwebx.worldbank.org/climateportal/index.cfm?page= country historical climate\&T

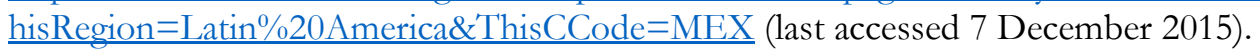

Xiang-zhou, X., Z. Hong-wu, and Z. Ouyang. 2004. Development of check-dam systems in gullies on the Loess Plateau, China. Environmental Science and Policy 7: 79-86.

Yang, D, S. Kanae, T.Oki, T. Koike, and K. Musiake. 2003. Global potential soil erosion with reference to land use and climate changes. Hydrological Processes 17: 2913-28.

Zhou, Y., Z. Yang, D. Zhang, X. Jin, and J. Zhang. 2015a. Inter-catchment comparison of flow regime between the Hailiutu and Huangfuchuan rivers in the semi-arid Erdos Plateau, Northwest China. Hydrological Sciences Journal 60(4): 688-705.

Zhou, Y, C. Shi, X. Fan, and W. Shao. 2015b. The influence of climate change and anthropogenic activities on annual runoff of Huangfuchuan basin in northwest China. Theoretical and Applied Climatology 120: 137-46. 


\section{Appendix A}

Frequency factor look up table for the calculation of $K$ values 
Table A1. K value look up table.

\begin{tabular}{|c|c|c|c|c|c|c|c|c|}
\hline \multirow{2}{*}{$\begin{array}{c}\text { Skew } \\
\text { Coefficient }\end{array}$} & \multicolumn{8}{|c|}{ Recurrence Interval In Years } \\
\hline & 1.0101 & 2 & 5 & 10 & 25 & 50 & 100 & 200 \\
\hline 3 & -0.667 & -0.396 & 0.42 & 1.18 & 2.278 & 3.152 & 4.051 & 4.97 \\
\hline 2.9 & -0.69 & -0.39 & 0.44 & 1.195 & 2.277 & 3.134 & 4.013 & 4.904 \\
\hline 2.8 & -0.714 & -0.384 & 0.46 & 1.21 & 2.275 & 3.114 & 3.973 & 4.847 \\
\hline 2.7 & -0.74 & -0.376 & 0.479 & 1.224 & 2.272 & 3.093 & 3.932 & 4.783 \\
\hline 2.6 & -0.769 & -0.368 & 0.499 & 1.238 & 2.267 & 3.071 & 3.889 & 4.718 \\
\hline 2.5 & -0.799 & -0.36 & 0.518 & 1.25 & 2.262 & 3.048 & 3.845 & 4.652 \\
\hline 2.4 & -0.832 & -0.351 & 0.537 & 1.262 & 2.256 & 3.023 & 3.8 & 4.584 \\
\hline 2.3 & -0.867 & -0.341 & 0.555 & 1.274 & 2.248 & 2.997 & 3.753 & 4.515 \\
\hline 2.2 & -0.905 & -0.33 & 0.574 & 1.284 & 2.24 & 2.97 & 3.705 & 4.444 \\
\hline 2.1 & -0.946 & -0.319 & 0.592 & 1.294 & 2.23 & 2.942 & 3.656 & 4.372 \\
\hline 2 & -0.99 & -0.307 & 0.609 & 1.302 & 2.219 & 2.912 & 3.605 & 4.298 \\
\hline 1.9 & -1.037 & -0.294 & 0.627 & 1.31 & 2.207 & 2.881 & 3.553 & 4.223 \\
\hline 1.8 & -1.087 & -0.282 & 0.643 & 1.318 & 2.193 & 2.848 & 3.499 & 4.147 \\
\hline 1.7 & -1.14 & -0.268 & 0.66 & 1.324 & 2.179 & 2.815 & 3.444 & 4.069 \\
\hline 1.6 & -1.197 & -0.254 & 0.675 & 1.329 & 2.163 & 2.78 & 3.388 & 3.99 \\
\hline 1.5 & -1.256 & -0.24 & 0.69 & 1.333 & 2.146 & 2.743 & 3.33 & 3.91 \\
\hline 1.4 & -1.318 & -0.225 & 0.705 & 1.337 & 2.128 & 2.706 & 3.271 & 3.828 \\
\hline 1.3 & -1.383 & -0.21 & 0.719 & 1.339 & 2.108 & 2.666 & 3.211 & 3.745 \\
\hline 1.2 & -1.449 & -0.195 & 0.732 & 1.34 & 2.087 & 2.626 & 3.149 & 3.661 \\
\hline 1.1 & -1.518 & -0.18 & 0.745 & 1.341 & 2.066 & 2.585 & 3.087 & 3.575 \\
\hline 1 & -1.588 & -0.164 & 0.758 & 1.34 & 2.043 & 2.542 & 3.022 & 3.489 \\
\hline 0.9 & -1.66 & -0.148 & 0.769 & 1.339 & 2.018 & 2.498 & 2.957 & 3.401 \\
\hline 0.8 & -1.733 & -0.132 & 0.78 & 1.336 & 1.993 & 2.453 & 2.891 & 3.312 \\
\hline 0.7 & -1.806 & -0.116 & 0.79 & 1.333 & 1.967 & 2.407 & 2.824 & 3.223 \\
\hline 0.6 & -1.88 & -0.099 & 0.8 & 1.328 & 1.939 & 2.359 & 2.755 & 3.132 \\
\hline 0.5 & -1.955 & -0.083 & 0.808 & 1.323 & 1.91 & 2.311 & 2.686 & 3.041 \\
\hline 0.4 & -2.029 & -0.066 & 0.816 & 1.317 & 1.88 & 2.261 & 2.615 & 2.949 \\
\hline 0.3 & -2.104 & -0.05 & 0.824 & 1.309 & 1.849 & 2.211 & 2.544 & 2.856 \\
\hline 0.2 & -2.178 & -0.033 & 0.83 & 1.301 & 1.818 & 2.159 & 2.472 & 2.763 \\
\hline 0.1 & -2.252 & -0.017 & 0.836 & 1.292 & 1.785 & 2.107 & 2.4 & 2.67 \\
\hline 0 & -2.326 & 0 & 0.842 & 1.282 & 1.751 & 2.054 & 2.326 & 2.576 \\
\hline-0.1 & -2.4 & 0.017 & 0.846 & 1.27 & 1.716 & 2 & 2.252 & 2.482 \\
\hline-0.2 & -2.472 & 0.033 & 0.85 & 1.258 & 1.68 & 1.945 & 2.178 & 2.388 \\
\hline-0.3 & -2.544 & 0.05 & 0.853 & 1.245 & 1.643 & 1.89 & 2.104 & 2.294 \\
\hline-0.4 & -2.615 & 0.066 & 0.855 & 1.231 & 1.606 & 1.834 & 2.029 & 2.201 \\
\hline-0.5 & -2.686 & 0.083 & 0.856 & 1.216 & 1.567 & 1.777 & 1.955 & 2.108 \\
\hline-0.6 & -2.755 & 0.099 & 0.857 & 1.2 & 1.528 & 1.72 & 1.88 & 2.016 \\
\hline-0.7 & -2.824 & 0.116 & 0.857 & 1.183 & 1.488 & 1.663 & 1.806 & 1.926 \\
\hline-0.8 & -2.891 & 0.132 & 0.856 & 1.166 & 1.448 & 1.606 & 1.733 & 1.837 \\
\hline-0.9 & -2.957 & 0.148 & 0.854 & 1.147 & 1.407 & 1.549 & 1.66 & 1.749 \\
\hline-1 & -3.022 & 0.164 & 0.852 & 1.128 & 1.366 & 1.492 & 1.588 & 1.664 \\
\hline-1.1 & -3.087 & 0.18 & 0.848 & 1.107 & 1.324 & 1.435 & 1.518 & 1.581 \\
\hline-1.2 & -3.149 & 0.195 & 0.844 & 1.086 & 1.282 & 1.379 & 1.449 & 1.501 \\
\hline-1.3 & -3.211 & 0.21 & 0.838 & 1.064 & 1.24 & 1.324 & 1.383 & 1.424 \\
\hline-1.4 & -3.271 & 0.225 & 0.832 & 1.041 & 1.198 & 1.27 & 1.318 & 1.351 \\
\hline-1.5 & -3.33 & 0.24 & 0.825 & 1.018 & 1.157 & 1.217 & 1.256 & 1.282 \\
\hline-1.6 & -3.88 & 0.254 & 0.817 & 0.994 & 1.116 & 1.166 & 1.197 & 1.216 \\
\hline-1.7 & -3.444 & 0.268 & 0.808 & 0.97 & 1.075 & 1.116 & 1.14 & 1.155 \\
\hline-1.8 & -3.499 & 0.282 & 0.799 & 0.945 & 1.035 & 1.069 & 1.087 & 1.097 \\
\hline-1.9 & -3.553 & 0.294 & 0.788 & 0.92 & 0.996 & 1.023 & 1.037 & 1.044 \\
\hline-2 & -3.605 & 0.307 & 0.777 & 0.895 & 0.959 & 0.98 & 0.99 & 0.995 \\
\hline-2.1 & -3.656 & 0.319 & 0.765 & 0.869 & 0.923 & 0.939 & 0.946 & 0.949 \\
\hline-2.2 & -3.705 & 0.33 & 0.752 & 0.844 & 0.888 & 0.9 & 0.905 & 0.907 \\
\hline-2.3 & -3.753 & 0.341 & 0.739 & 0.819 & 0.855 & 0.864 & 0.867 & 0.869 \\
\hline-2.4 & -3.8 & 0.351 & 0.725 & 0.795 & 0.823 & 0.83 & 0.832 & 0.833 \\
\hline-2.5 & -3.845 & 0.36 & 0.711 & 0.711 & 0.793 & 0.798 & 0.799 & 0.8 \\
\hline-2.6 & -3.899 & 0.368 & 0.696 & 0.747 & 0.764 & 0.768 & 0.769 & 0.769 \\
\hline-2.7 & -3.932 & 0.376 & 0.681 & 0.724 & 0.738 & 0.74 & 0.74 & 0.741 \\
\hline-2.8 & -3.973 & 0.384 & 0.666 & 0.702 & 0.712 & 0.714 & 0.714 & 0.714 \\
\hline-2.9 & -4.013 & 0.39 & 0.651 & 0.681 & 0.683 & 0.689 & 0.69 & 0.69 \\
\hline-3 & -4.051 & 0.396 & 0.636 & 0.66 & 0.666 & 0.666 & 0.667 & 0.667 \\
\hline
\end{tabular}




\section{Appendix B}

Change in Stream power profiles with the upstream and downstream $\mathrm{D}_{50}$ distributions associated with the check dam(s) measured at each site 


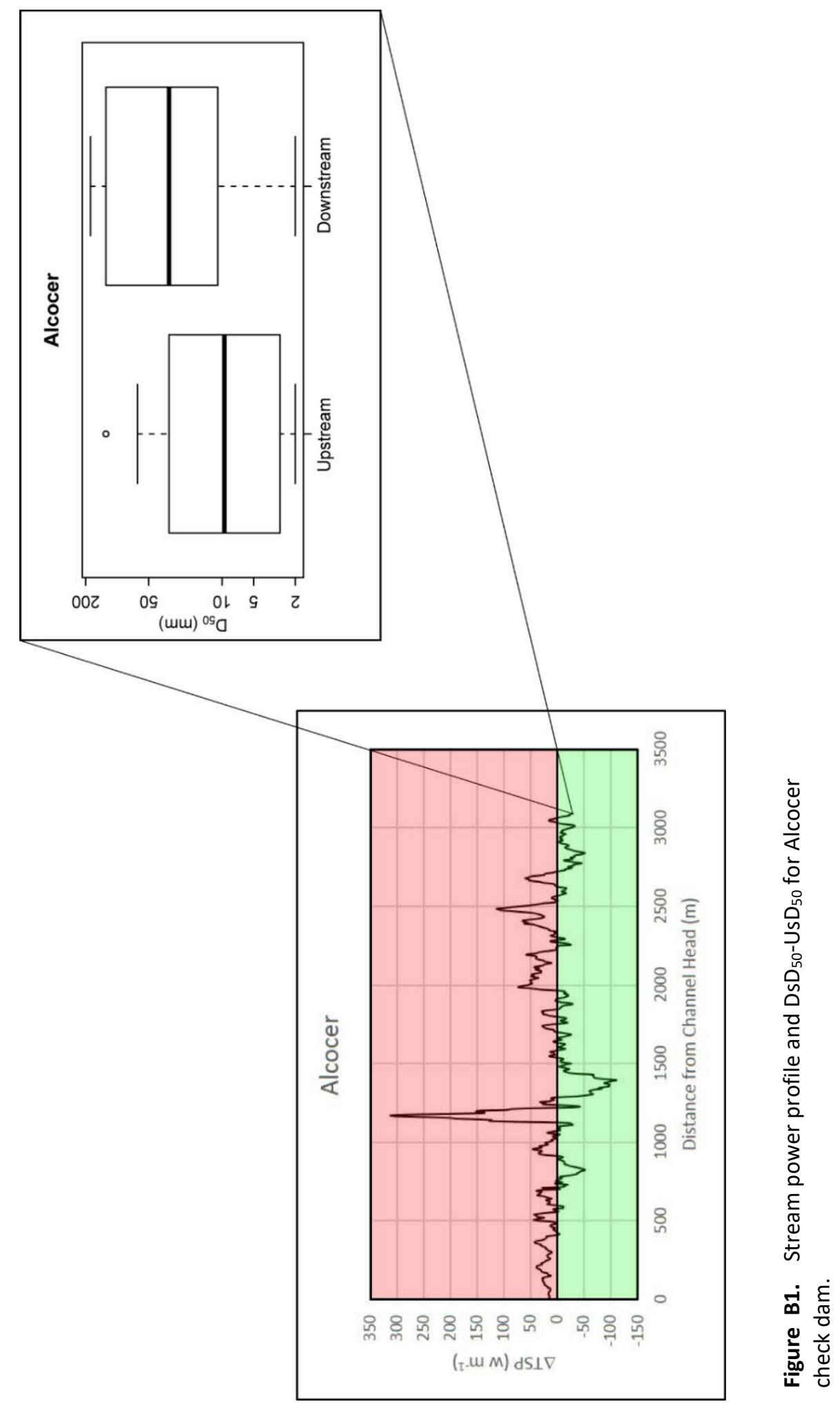




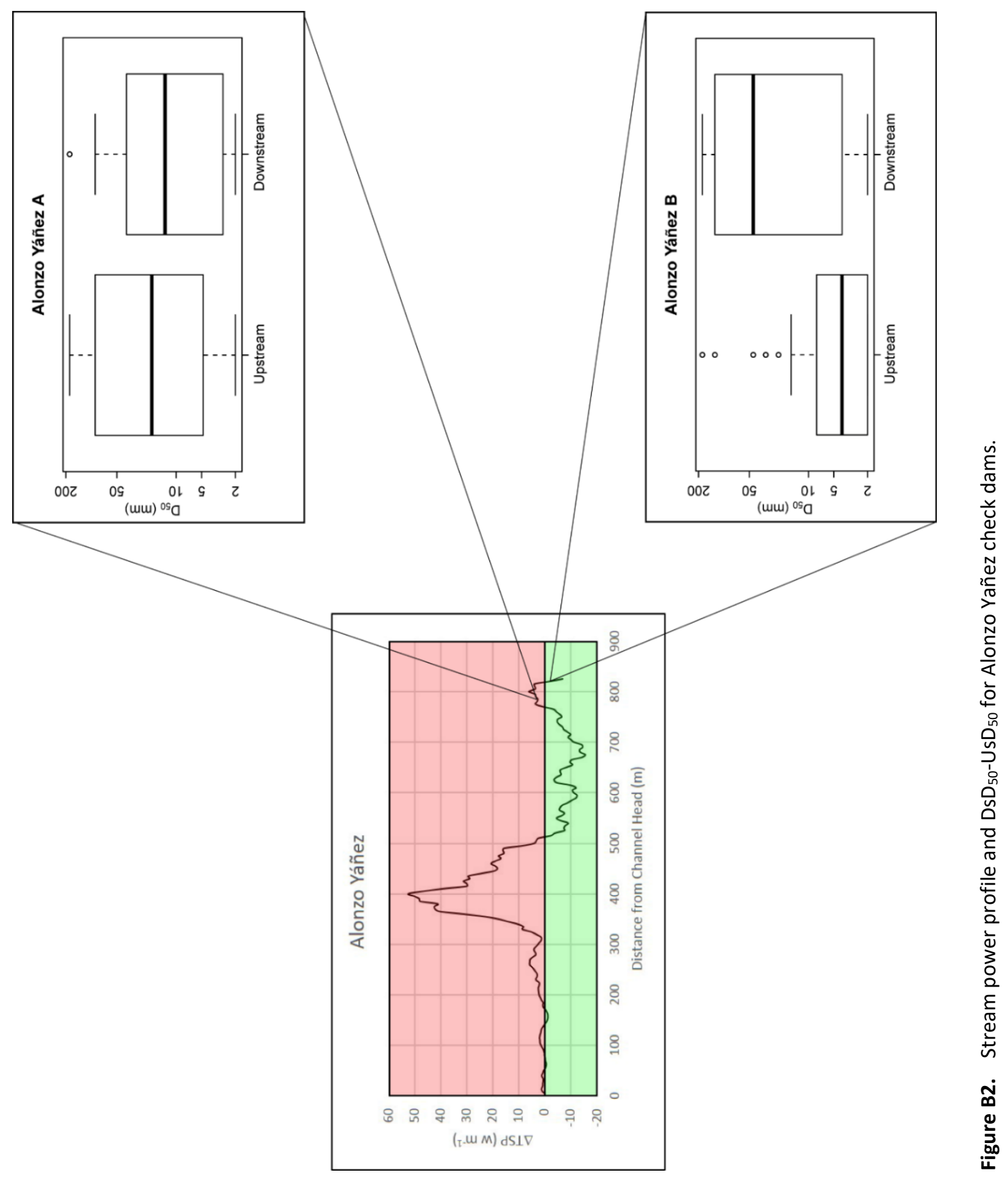




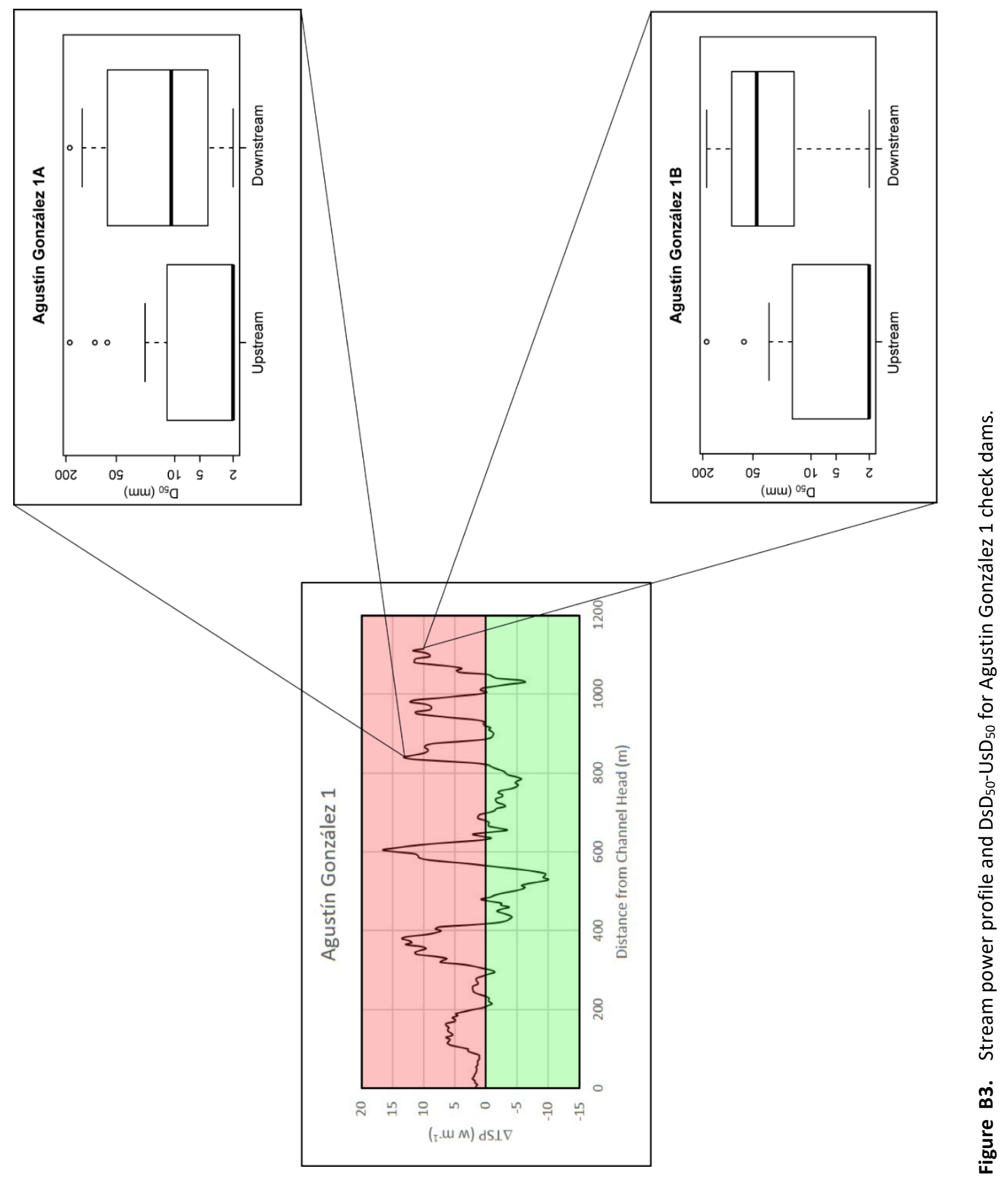




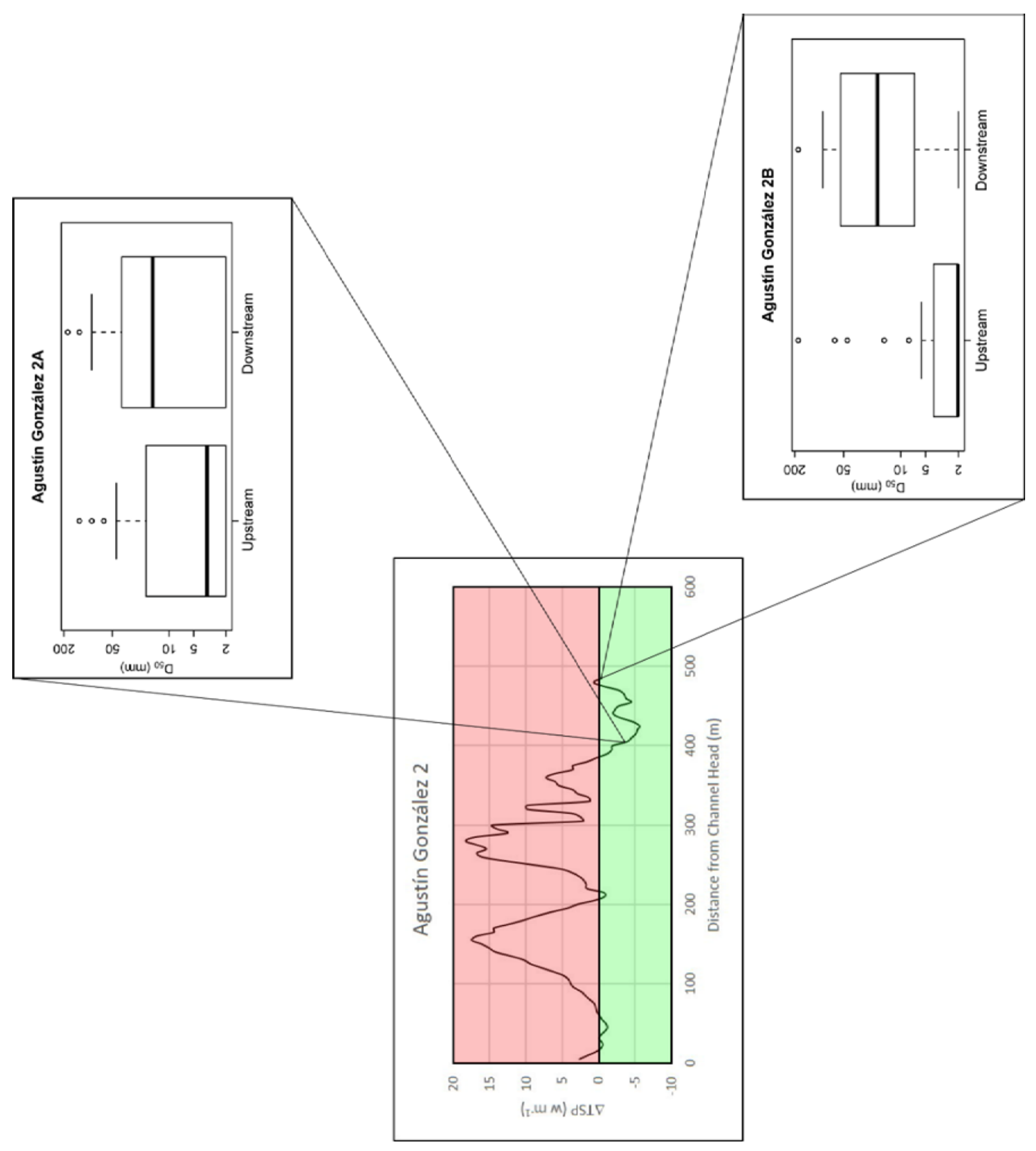

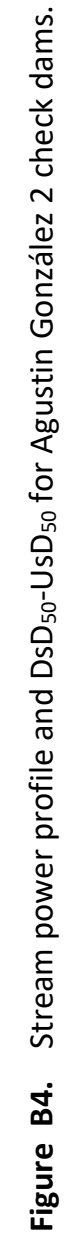




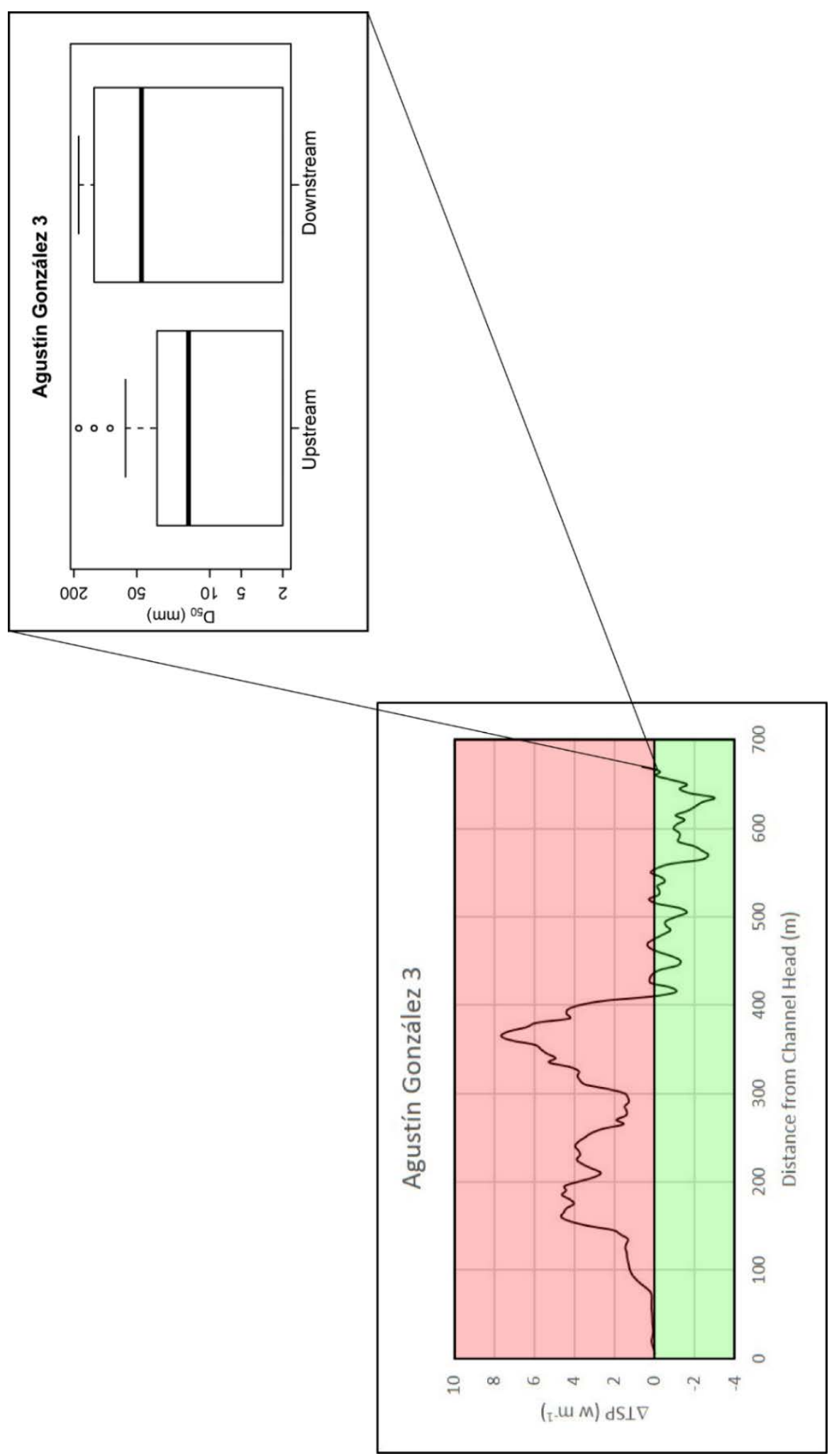

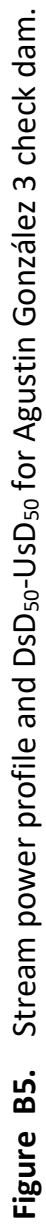




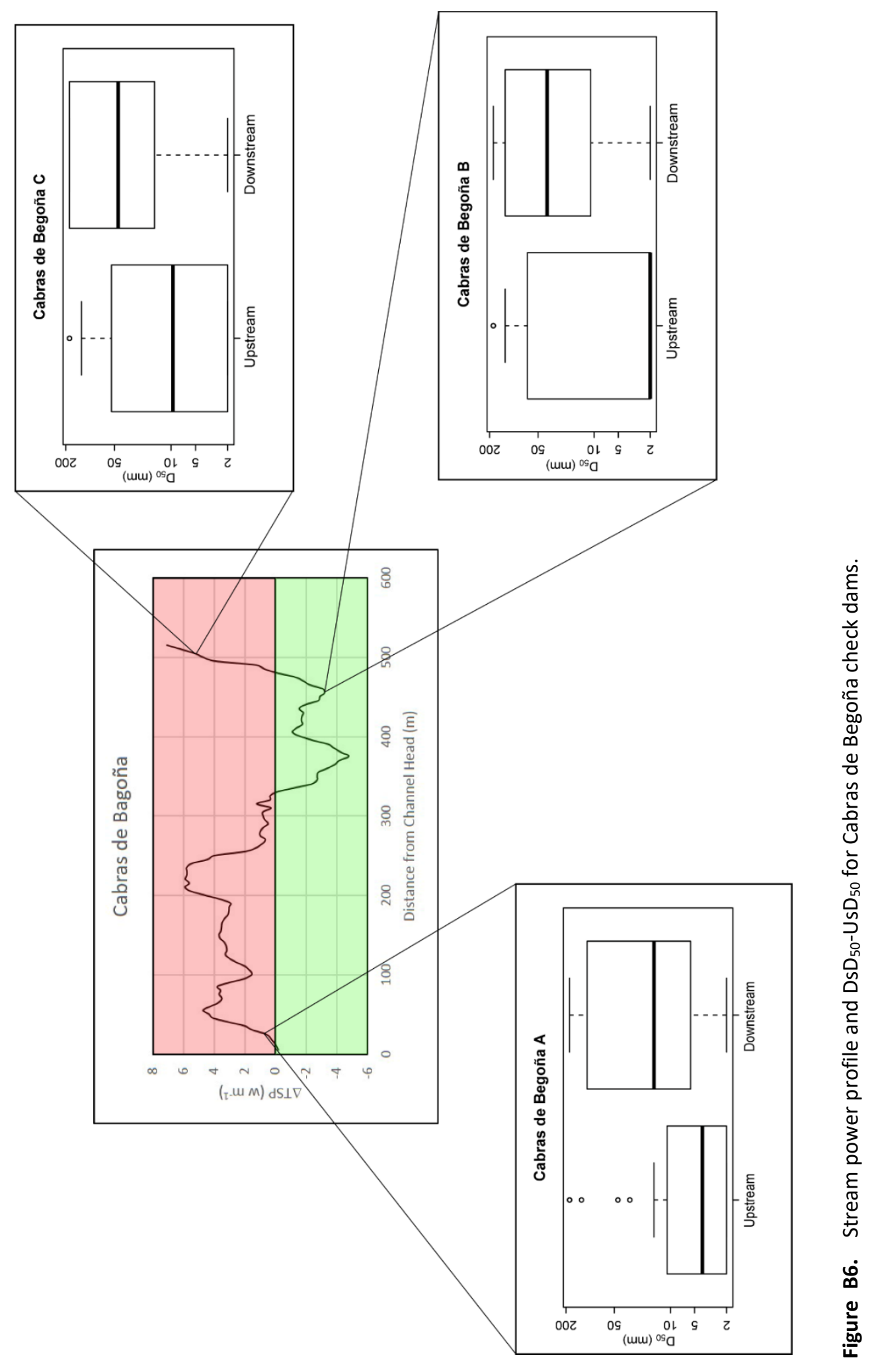




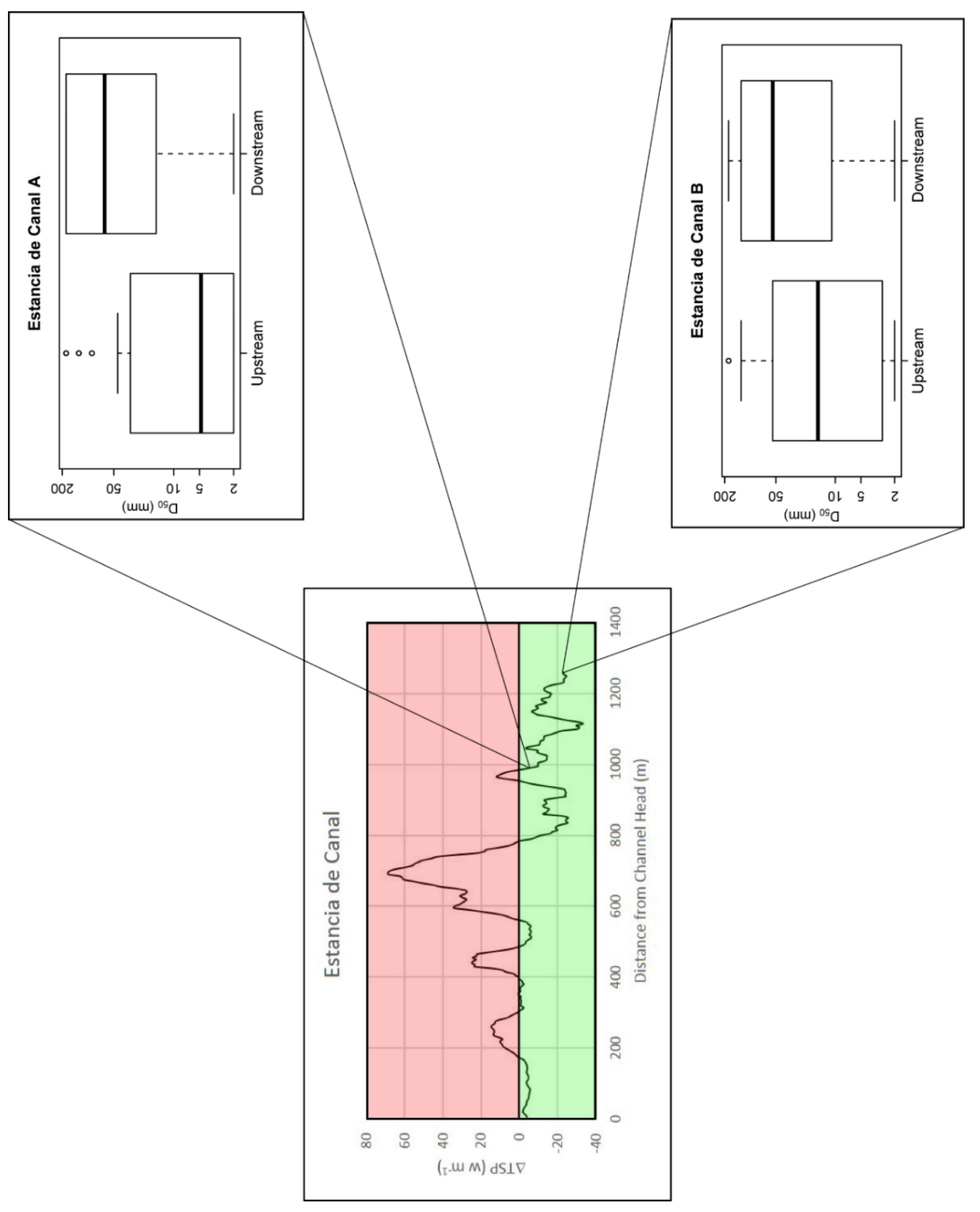

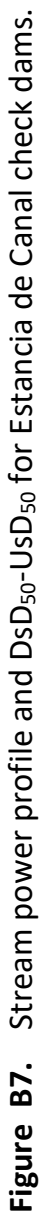




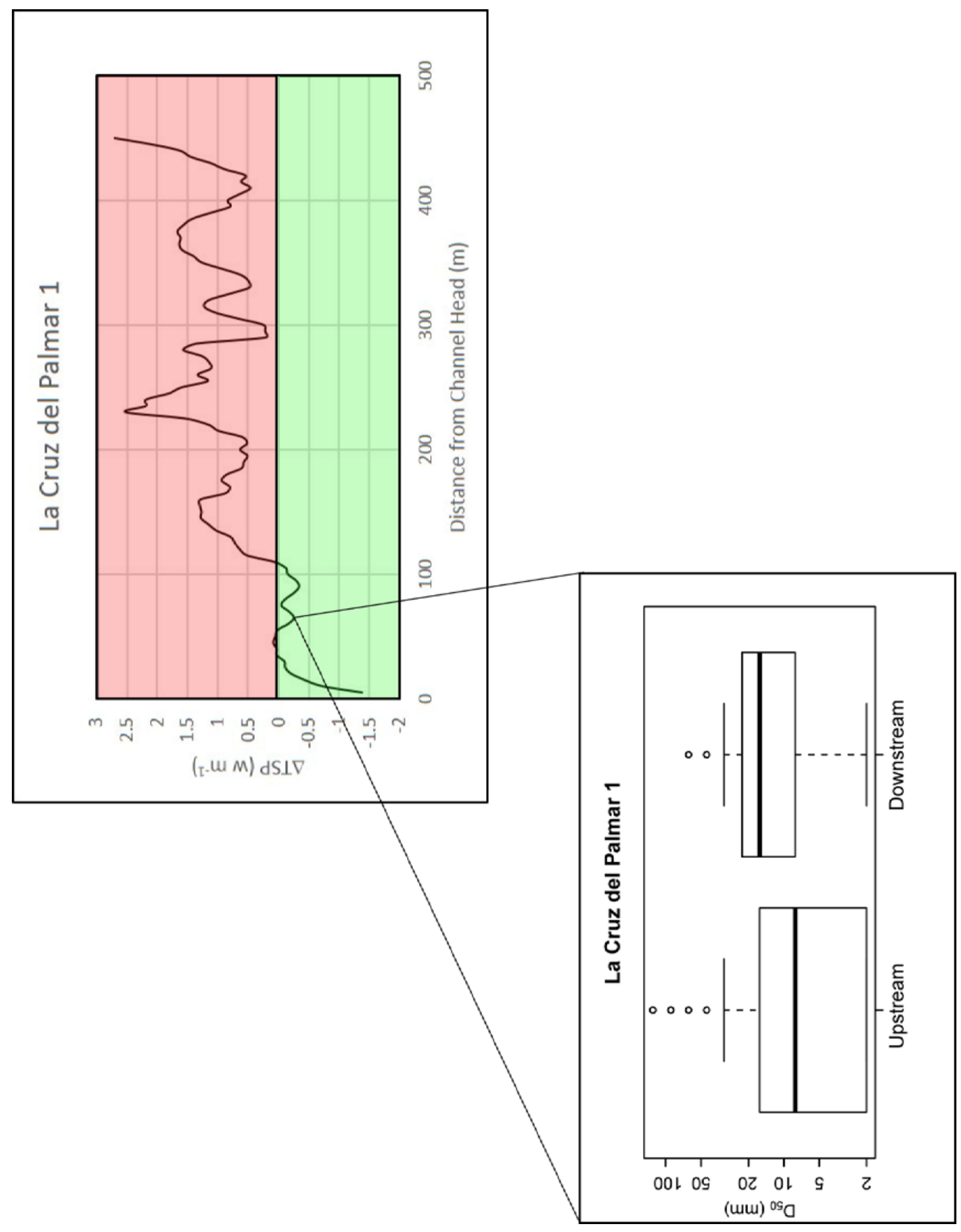

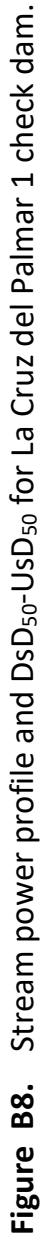




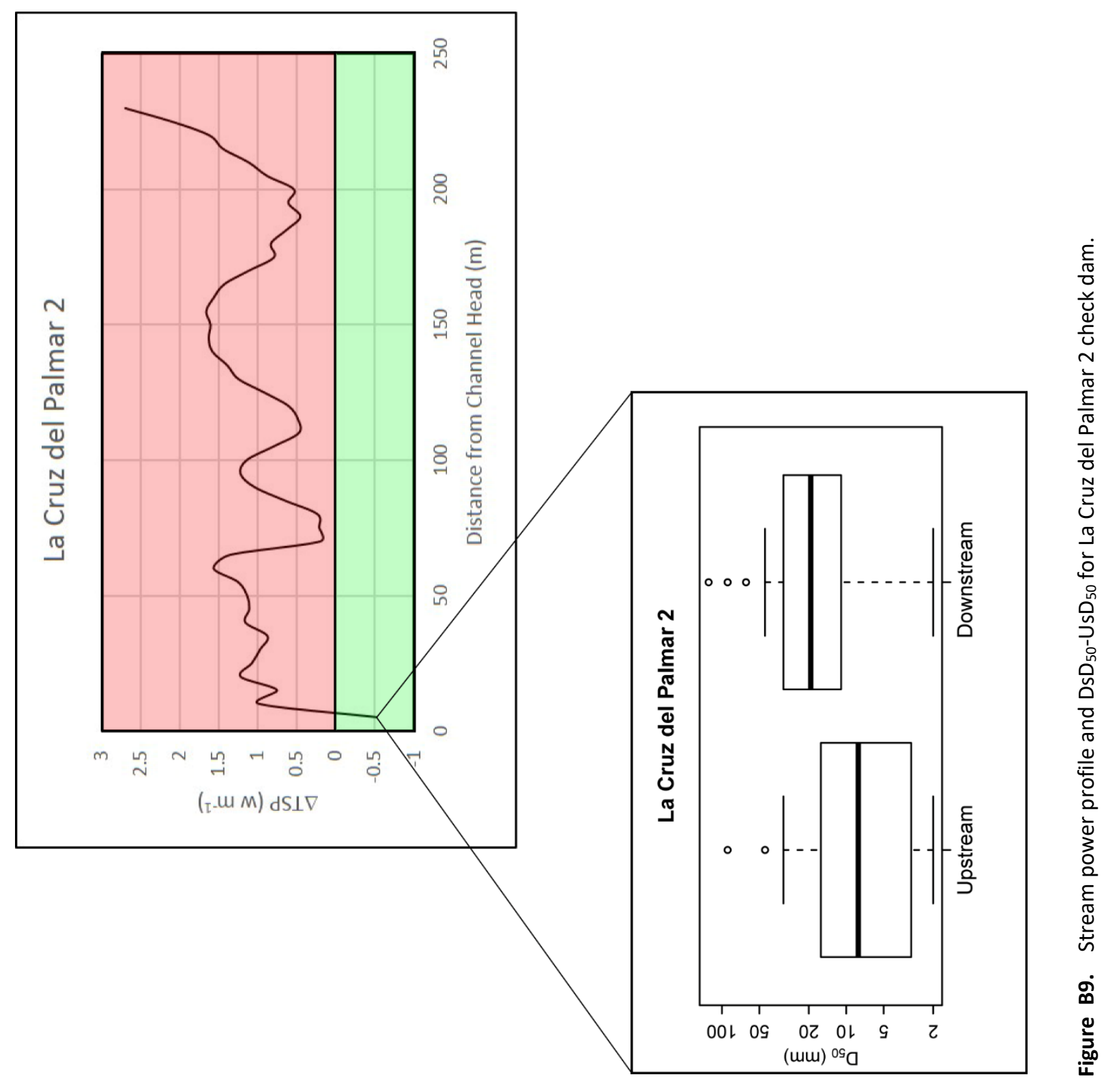




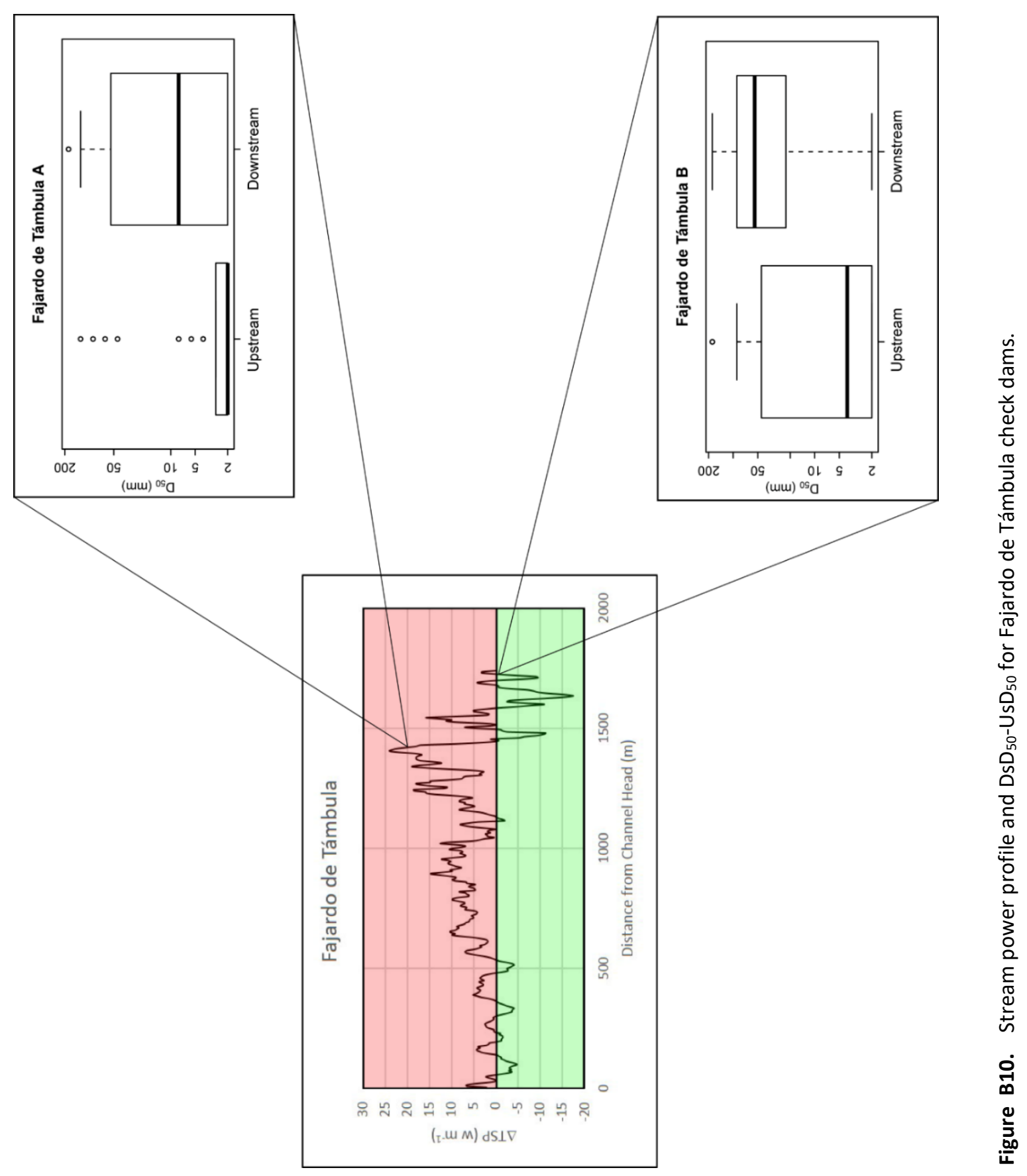




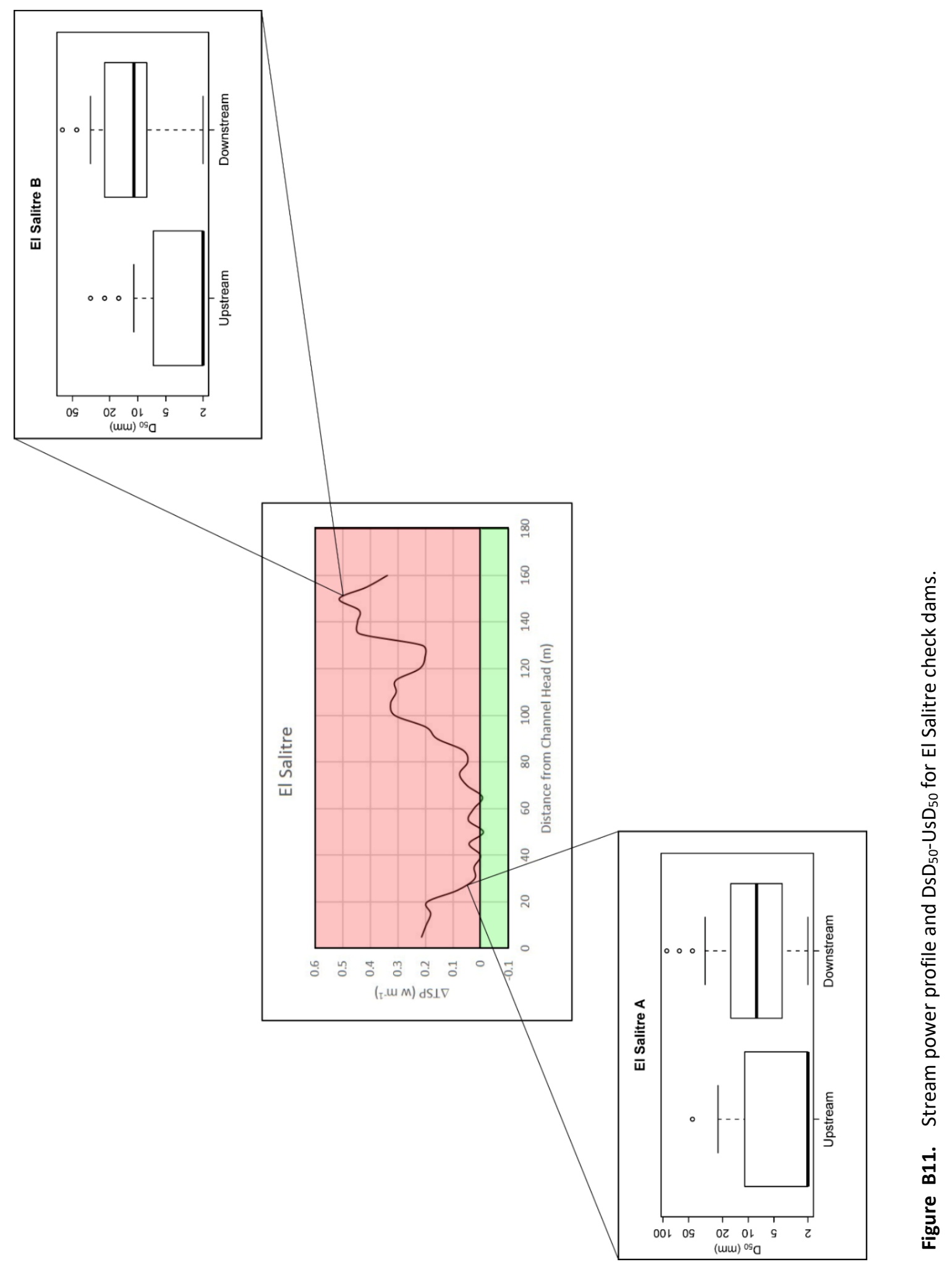




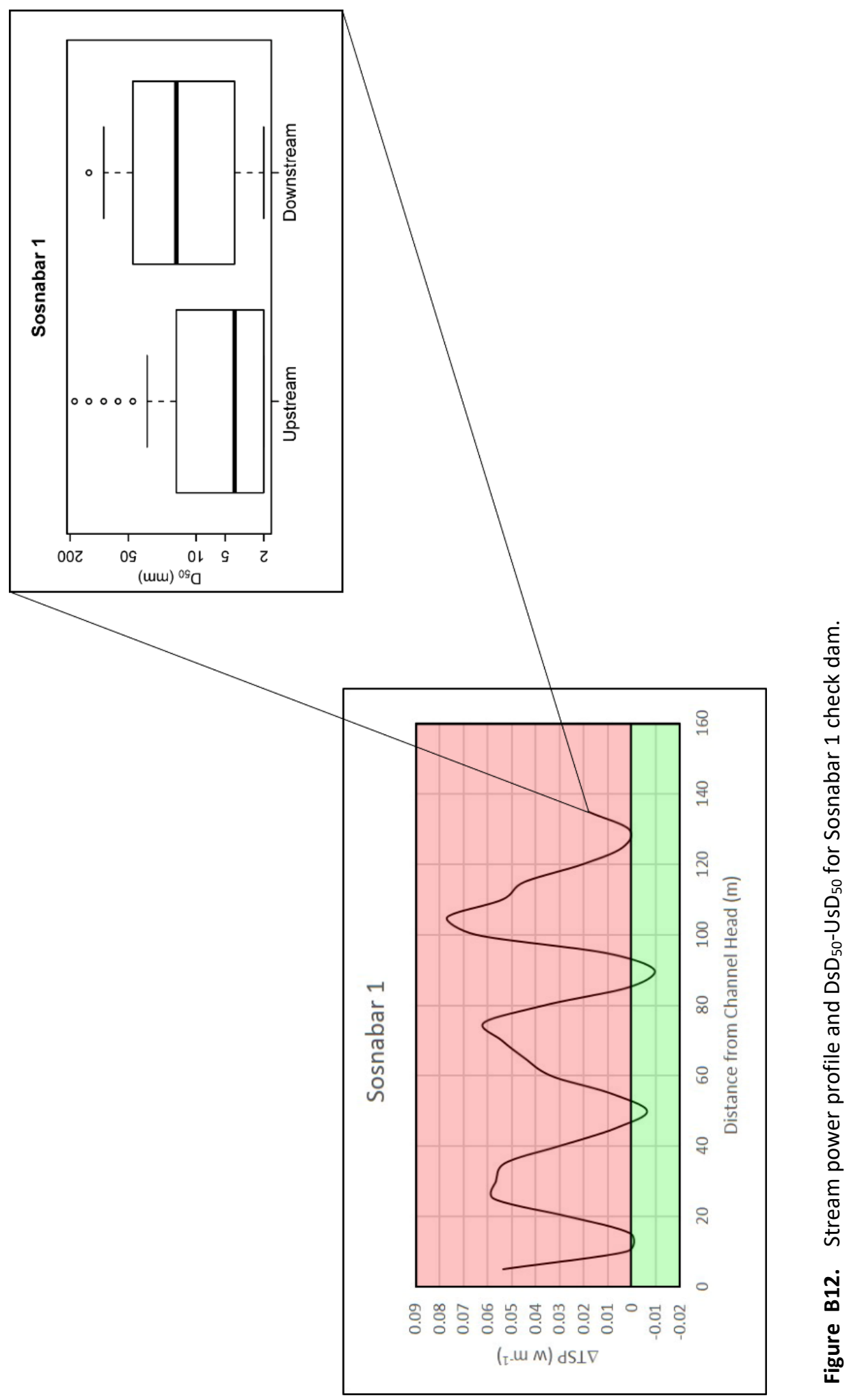




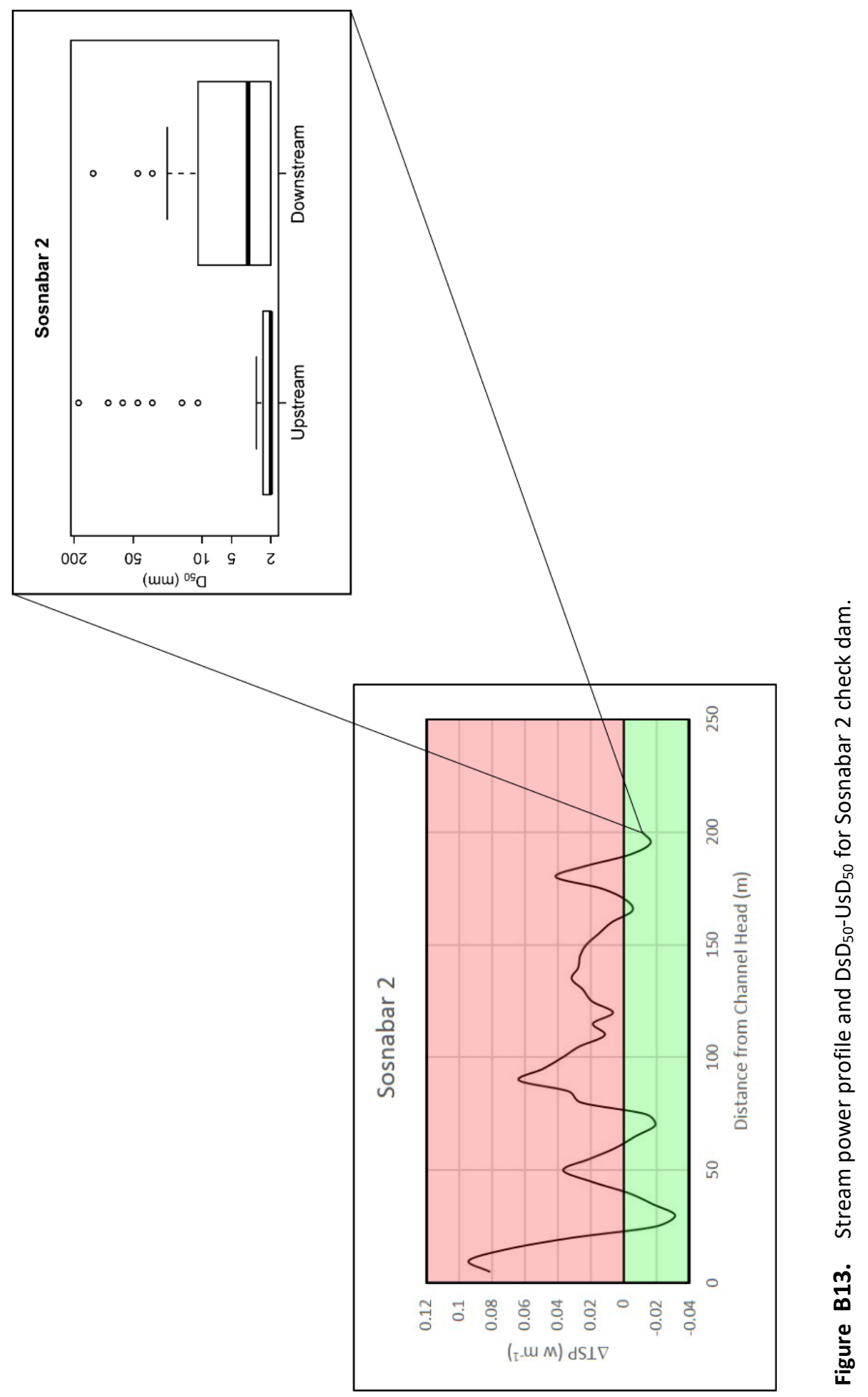




\section{Appendix C}

Stream power maps for each site 


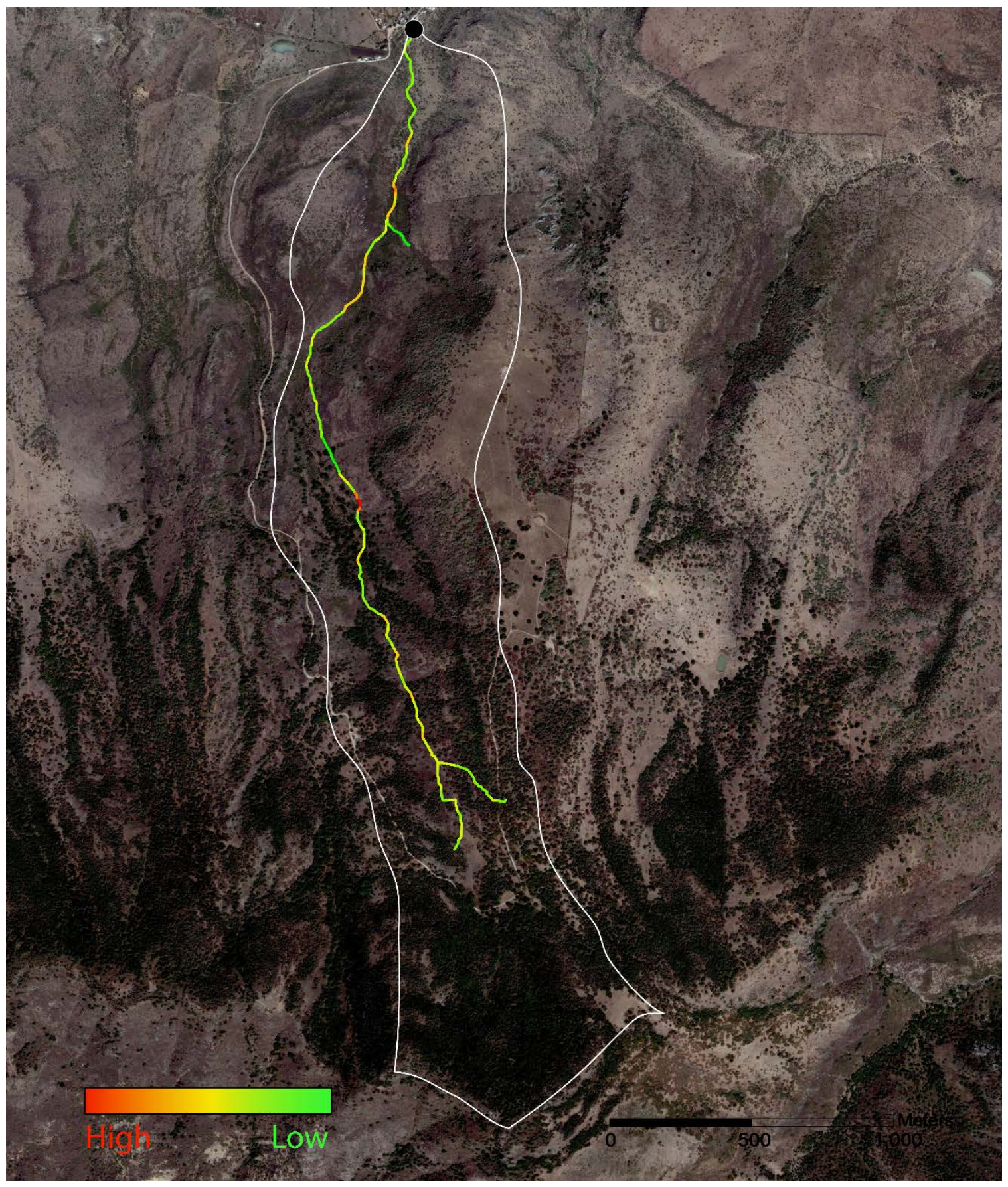

Figure C1. Stream power map for Alcocer. 


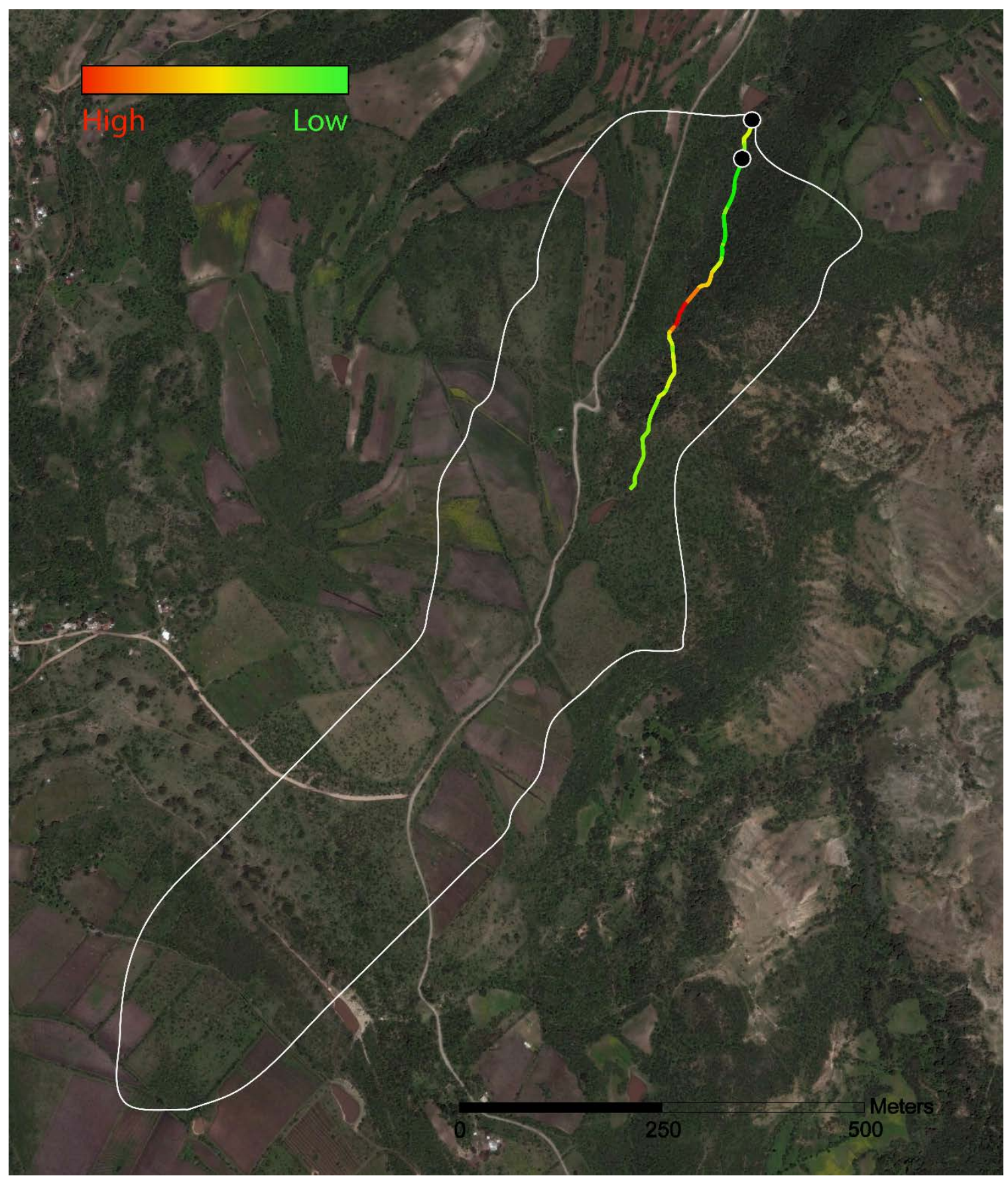

Figure C2. Stream power map for Alonzo Yañez. 


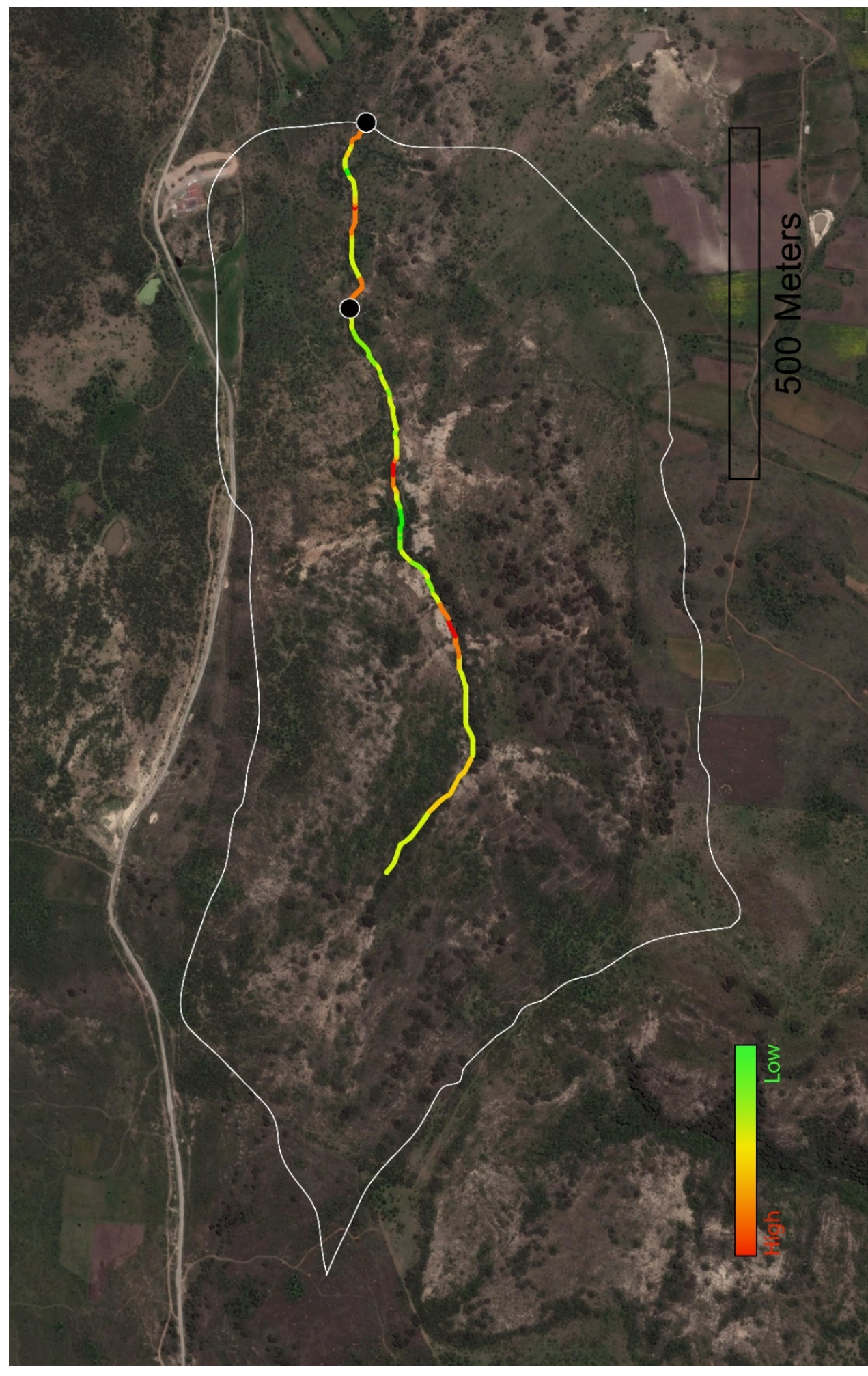

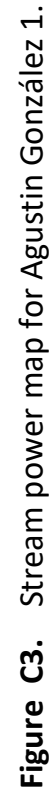




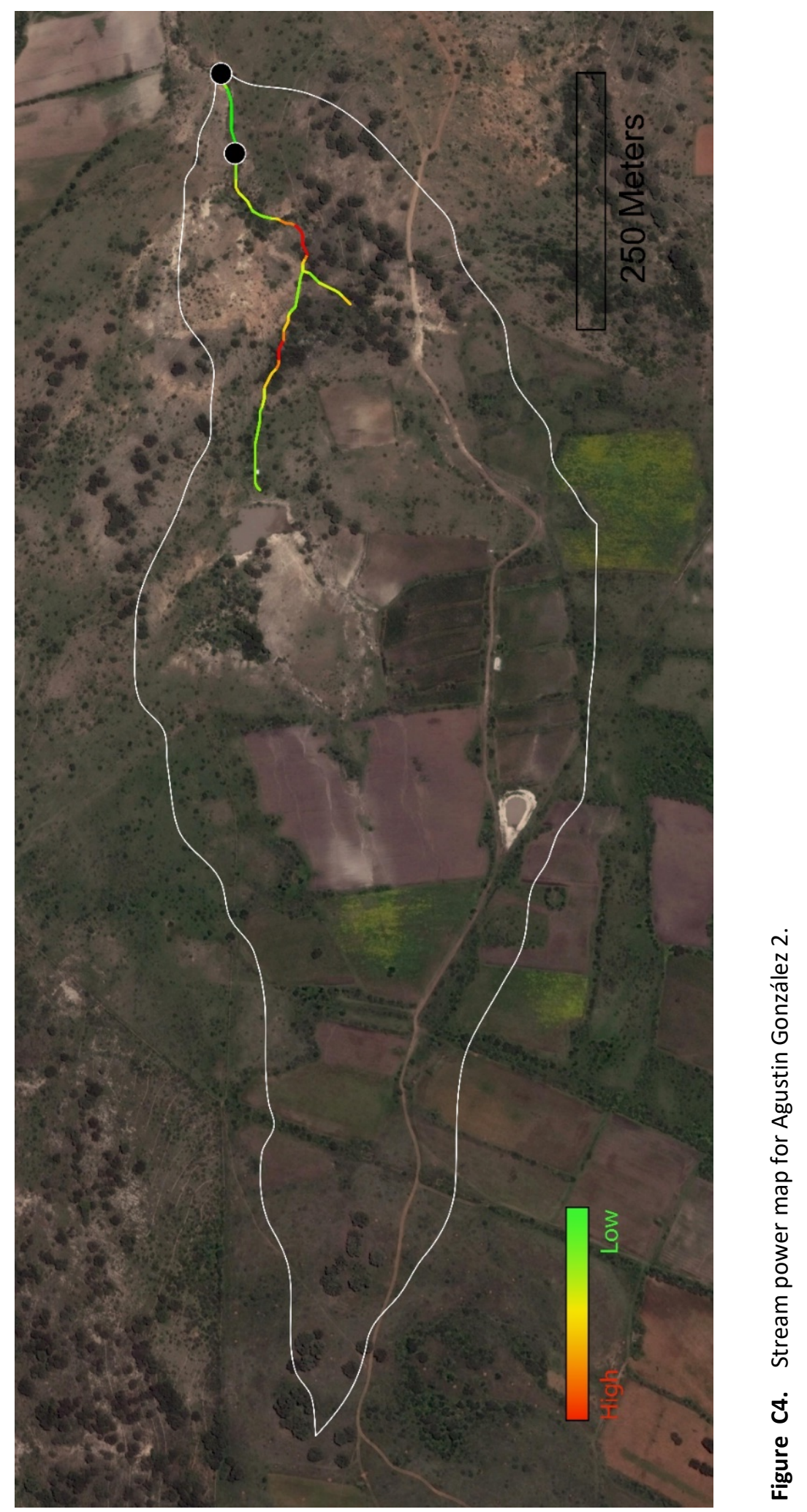




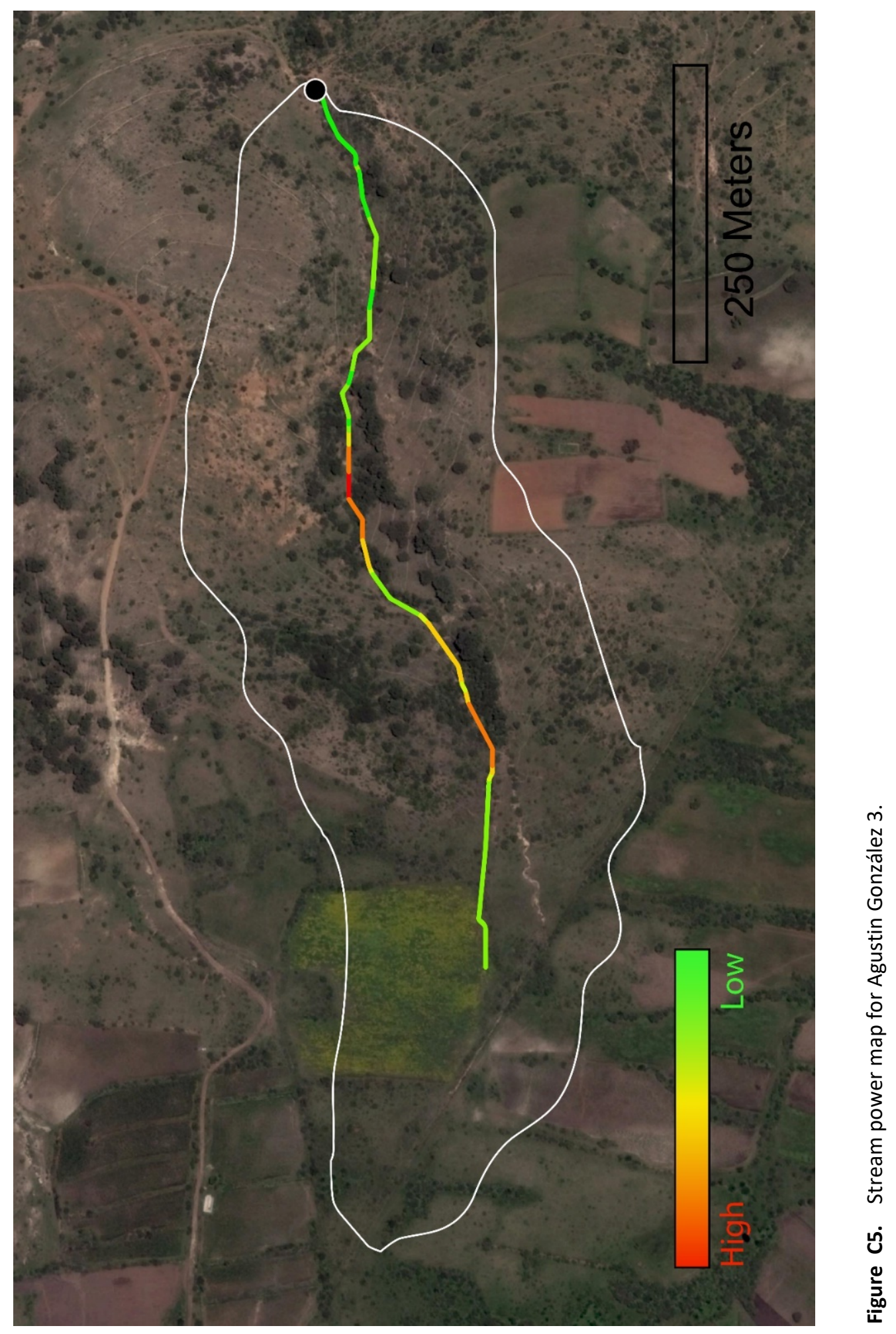




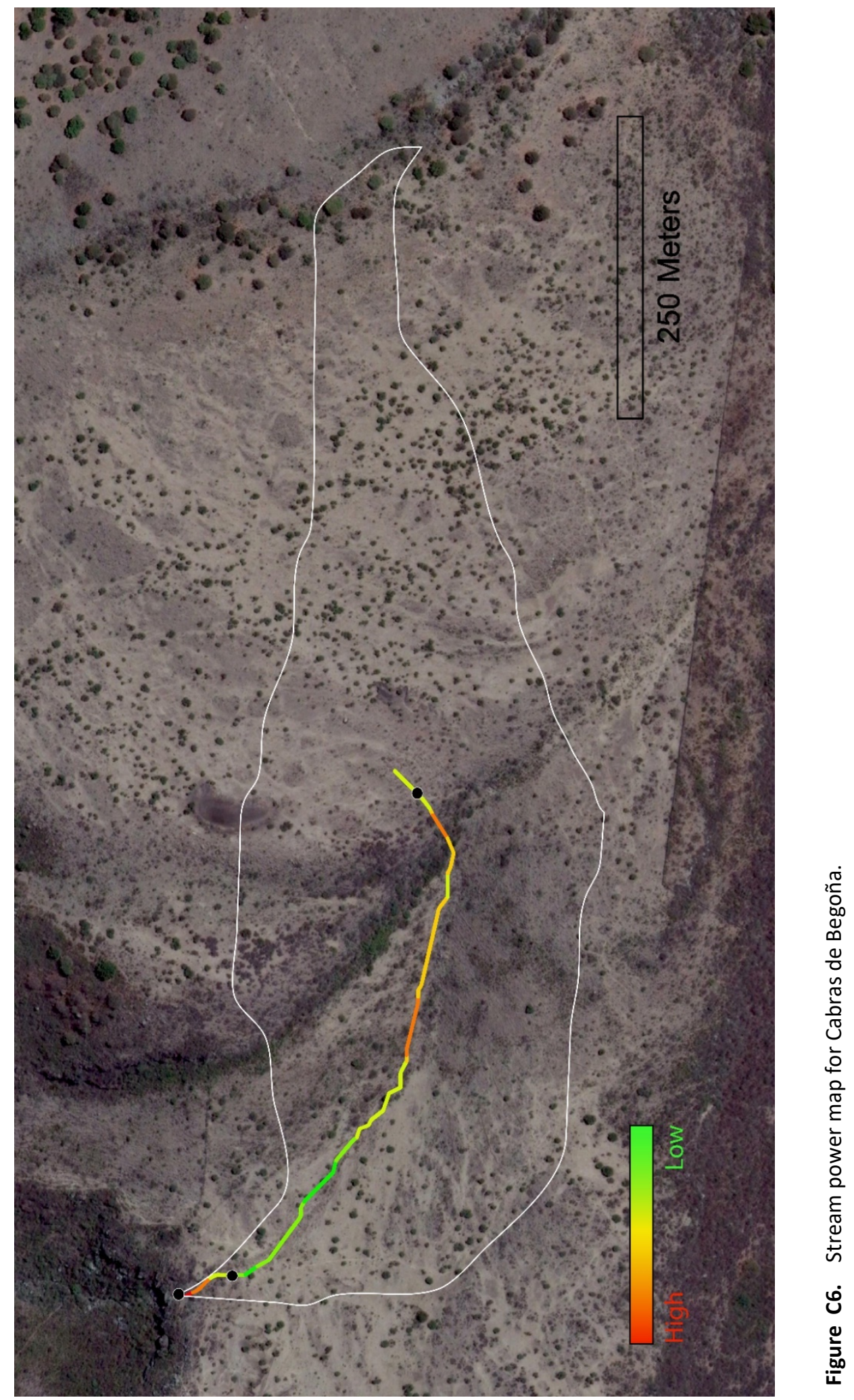




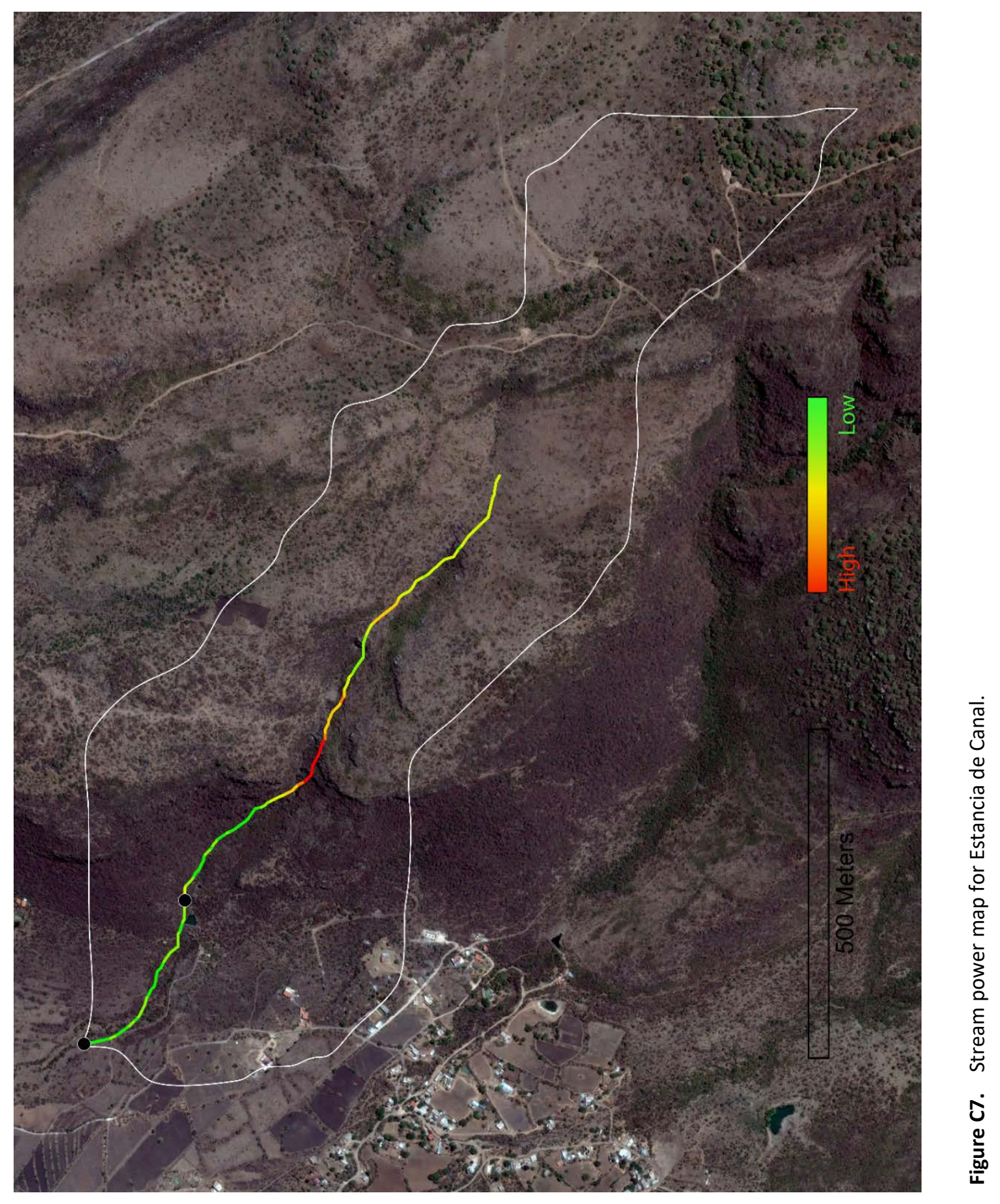




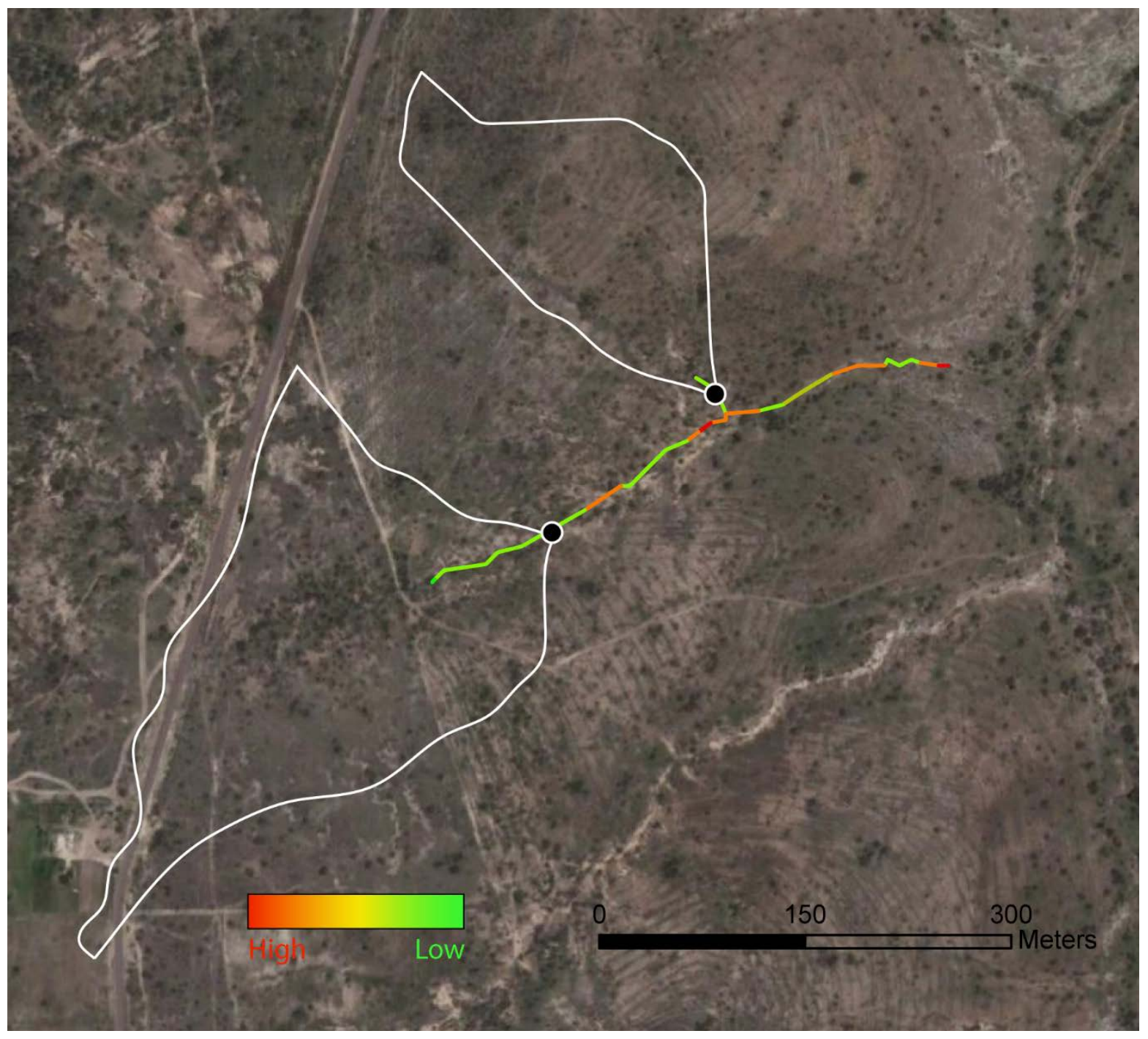

Figure C8. Stream power map for La Cruz del Palmar 1 and 2. 


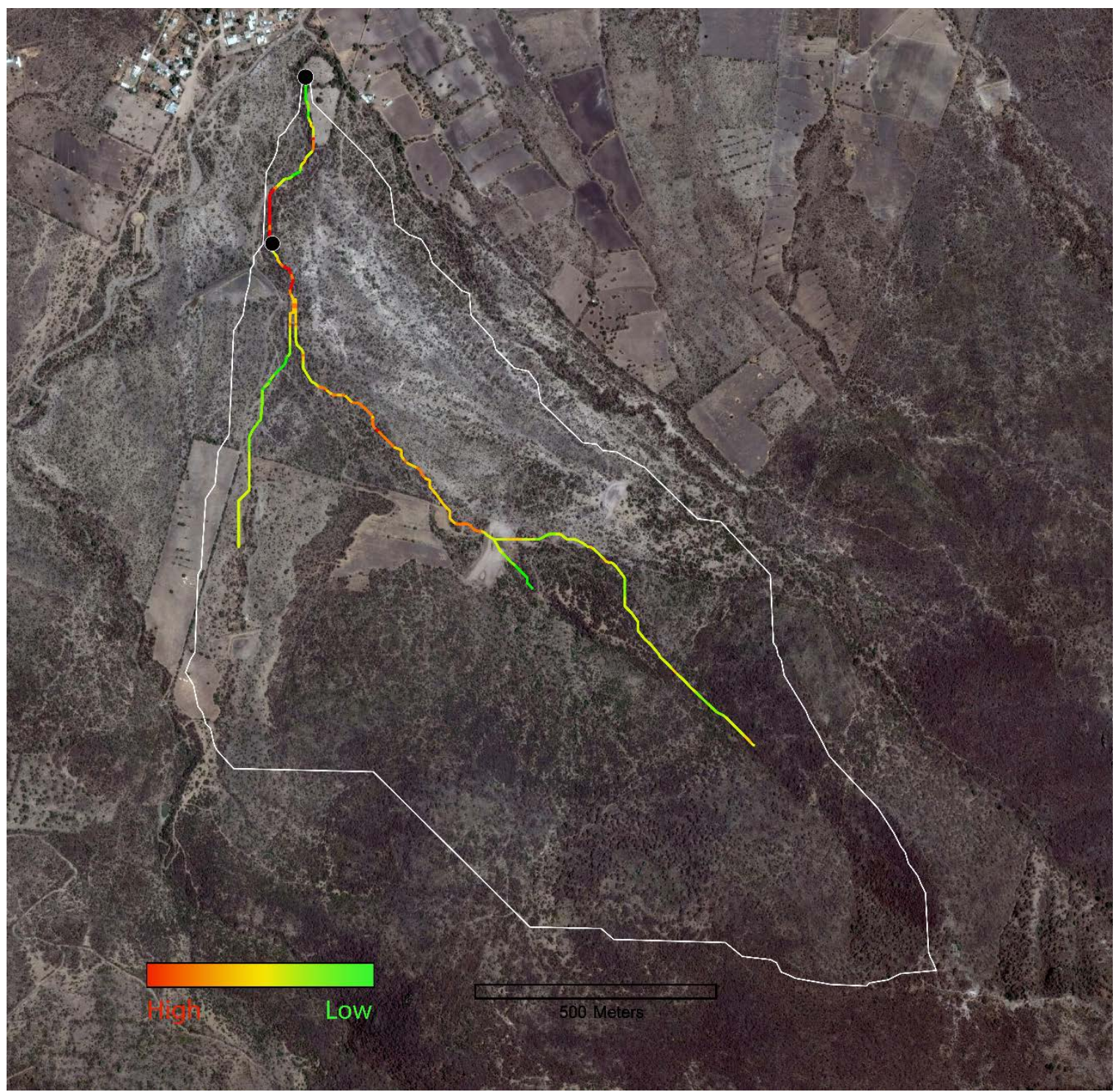

Figure C9. Stream power map for Fajardo de Támbula. 


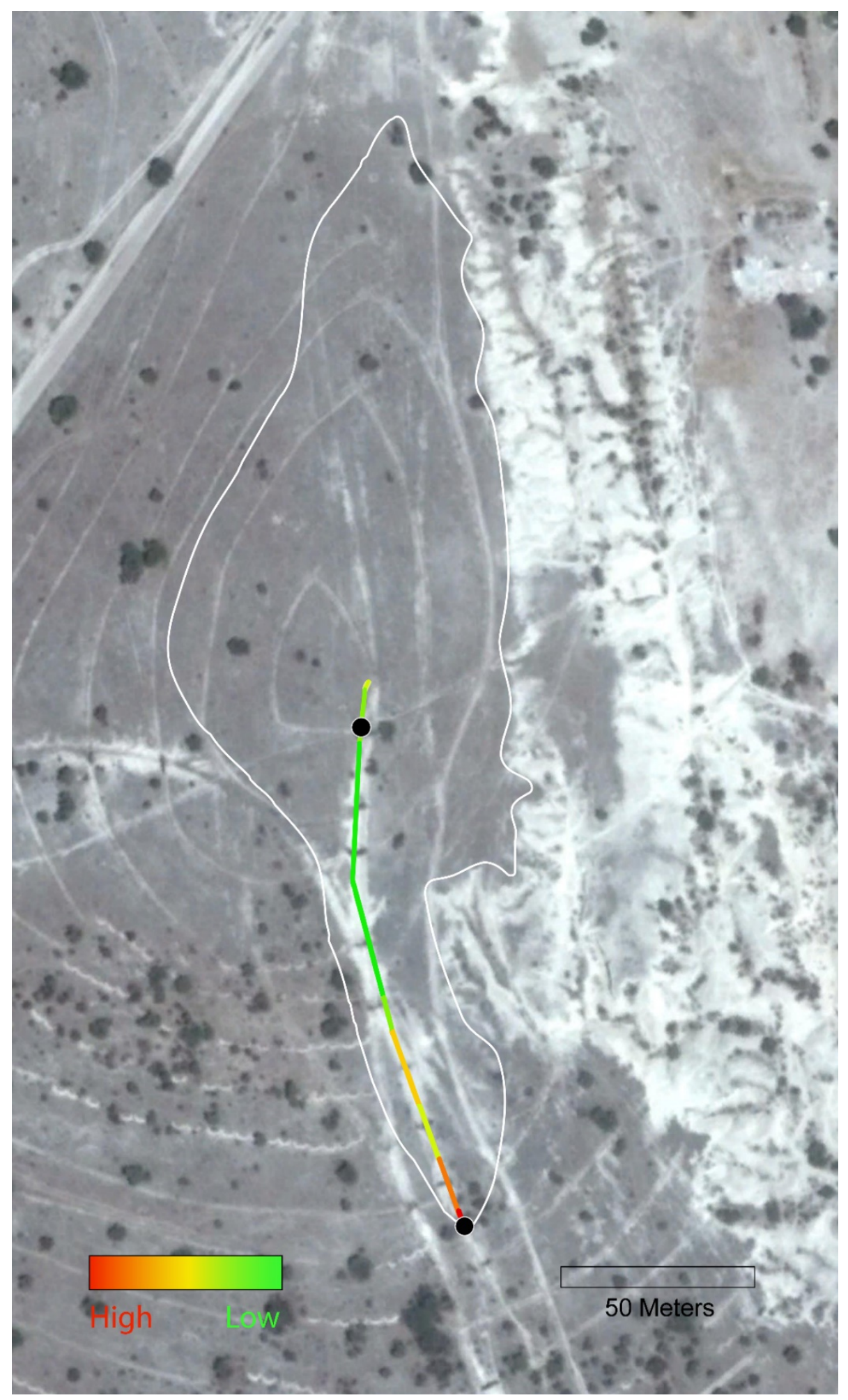

Figure C10. Stream power map for El Salitre. 


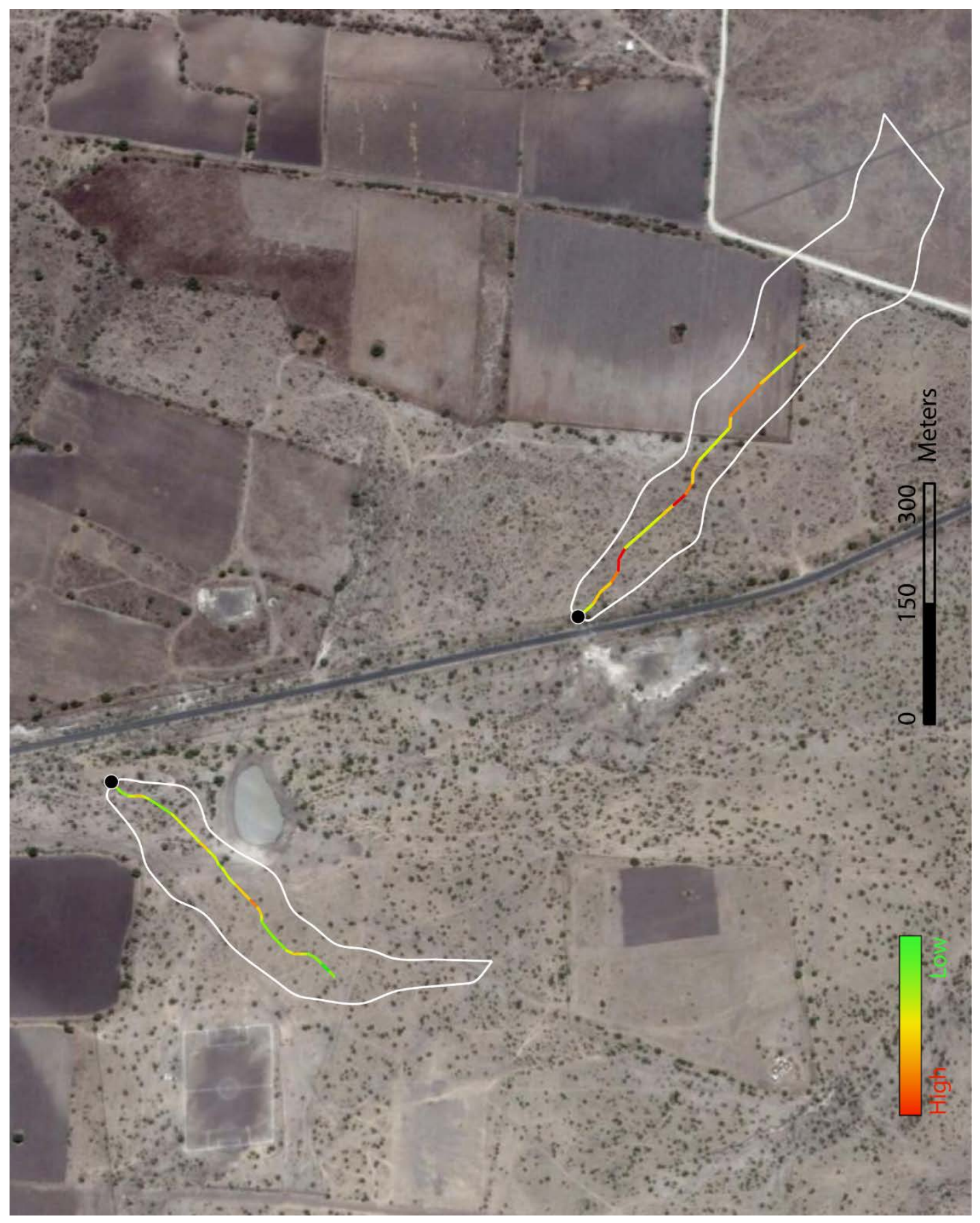

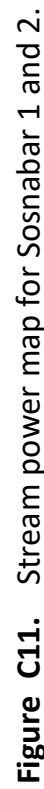

